\title{
第28回日本老年医学会総会 一般演題（IV）
}

204. 長谷川式痴呆診査スケールと Raven's coloured progressive matrices との比較検討一主として脳 梗塞患者について

都老人医療センター神経内科

$$
\begin{aligned}
& \text { 福岡 佳宏, 大川 義弘 } \\
& \text { 葛原 茂樹, 豊倉 康夫 }
\end{aligned}
$$

目的：Raven's coloured progressive matrices (CPM) は非言語的に抽象思考能力を検出し, 長谷川式 疾呆診查スケール（HDRS）とは異質な知能障害を評 価できる，両テストの評価成績には解離を示す例が少 なくない，我々は両テストの成績を比較し，主として 大脳皮質梗塞病巣局在の左右差及び巣症状との間の関 連性について検討した。

対象と方法：当院入院患者 45 例 '年齢60 84歳) を, 老年期痴呆 8 例, 右大脳皮質梗塞 6 例, 左皮質梗塞 6 例, 両側皮質梗塞 4 例, 正常対照群 21 例の 5 群に分け, HDRS, CPM の両者を全例に施行した。テスト成績は 各々の総得点㧊よび各評価段階で表わし, 各群間で比 較した。

結果：1）総得点は HDRS, CPM 共に老年期痴呆群 と正常対照群との間に有意な差が認められた.2）評価 段階では，老年期痴呆群は CPM-grade 4かつ HDRSPredementia (P) 3 例で, 他の 5 例は CPM-grade 5 または HDRS-Dementia (D) に属し, 正常対照群との 間に重畳は認められなかった。3)左梗塞群 6 例中 5 例 （他 1 例は HDRS-D, CPM grade 5で Gerstmann 症候 群合併例）は失語症を合併し HDRS-D に属したが, CPM ではらち 4 例が grade 3以上に分類された．4） 右梗塞群では HDRS が全例 Subnormal (S) 以上あっ たのに比し，CPM では半盲合併の 1 例を除きgrade 3一以下の低成績を示した。 5)両側梗塞群では両テスト 共低成績で, 構成障害合併の 2 例は, HDRS-S 及び P で CPM は共に grade 5に属した。 6) 半盲合併の 2 例 (左梗塞群 1 例, 右梗塞群 1 例) では, HDRS-S 及び D で CPM は共に grade 2であった。

結論：1）老年期痴呆群と正常対照群は, HDRS, CPM の各評価段階の組合せで区分可能であった，2) 右梗塞群は HDRS に比し CPM が低成績で視空間失 認合併例に顕著であった。3）視空間失認を伴わない視 野障害例ではCPMの成績は良好であった。4) HDRS, CPM 両テストを併用することによって，より
多面的な知能障害の評価が期待できる。

\section{5. 後大脳動脈領域の梗塞と痴呆一臨床病理学的検} 討一

$\begin{array}{lrr}\text { 都老人研臨床病理桜井博文, 吉村 } & \text { 正博 } \\ \text { 都老人医療センター病理部 } & \text { 嶋田 } \text { 裕之 } \\ \text { 同 神経内科 山之内 博, 葛原 } & \text { 茂樹 } \\ \text { 東大脳研病理 } & \text { 朝長 } & \text { 正徳 } \\ \text { 東京医大老年科 } & \text { 勝沼 } & \text { 英宇 }\end{array}$

目的：痴呆の発現に拈いて海馬は重要な部位の一つ である，後大脳動脈（以下 PCA）領域に梗塞の主病変 を有し, 老人性変化の合併の少い 20 剖検例を用いて, 合併する海馬病変の有無, PCA 領域梗塞の左右と痴呆 の出現を検討した．更に，脳弓を介して海馬へ投射す るとされている Medial septal area (以下 MSA) の ニューロンについて, PCA 梗塞例で，いかなる 2 次性 の変化が見られるかを検討した。

方法：都老人医療センターに扮ける老年者剖検例よ ク，以下の条件を満たす20例を描出した。 (1) PCA 領域 に中等大以上の梗塞病変を有すること. (2)血管性痴呆 の原因となりらる他の場所に著明な病変を合併しない こと. (3)老人斑, Alzheimer 原線維変化などの老人性 変化の程度が軽いこと。これらの 20 症例について痴呆 の有無を検討した。なお, 梗塞病変は, 剖検脳の幅 $1 \mathrm{~cm}$ の前額断の各面に拈いて検索し, 痴呆の有無は, 病歴 より判定した。 また， 3 症例について，PCA 梗塞と同 側の MSA を非障害側である反対側の MSA と比較検 討した。

結果：対象とした PCA 領域梗塞20例のうち, 痴呆 の出現は, 左側病変で, 海馬病変を含んだ 4 例中 4 例, 海馬病変を含まない 3 例中 2 例, 右側病変で, 海馬病 変を含んだ 4 例中 1 例, 海馬病変を含まない 5 例中 1 例, 左右病変で海馬病変を含んだ 2 例中 2 例, 海馬病 変を含まない 2 例中 1 例に認められた。

また, MSAを検討した 3 例のらち， 2 例では明らか な左右差を認めなかった。1例では，PCA 梗塞と同側 のMSA の 2 次性と思われる細胞減少や萎縮性変化を 認めたが，その程度は軽度であった。この意義につい ては，今後，検討する価値があると思われる。 
206. 痴呆患者における死因について

浴風会病院内科

$\begin{array}{rr}\text { 杉野 } & \text { 正一, 新野 直明, 大友 英一 } \\ \text { 同 病理 } & \text { 早川 道夫 }\end{array}$

目的：剖検例を用いて，アルッハイマー型痴呆 （DAT）及び脳血管性痴呆（VD）の死因について検討 した.

方法：臨床所見及び剖検所見により, DAT 群(平均 年龄 $82.8 \pm 8.8$ 歳), $\mathrm{VD}$ 群 $(83.4 \pm 7.3$ 歳) 及び生前痴 呆を認めなかった高齢者群 (84.2 27.8 歳)を各30例づ つ選択し, 原死因, 原死因発生時の痴呆の程度や $\mathrm{ADL}$, 痴呆発現後の生存期間等について調査し, 各群間にお いて対比検討した。尚知呆の程度は 3 段階（軽度，中 等度, 高度), ADL についても 3 段階 (良好, 中等度 障害，重度障害）に評価を行なった。

結果：(1) 死因別にみた死亡頻度は, DAT 群では, (1)肺炎・気管支炎 $13.3 \%$ ，(2)消化管出血 $16.6 \%$ ，(3)覀 性新生物 $13.3 \%, \mathrm{VD}$ 群では(1)脳血管疾患 $30.0 \%$, (2)肺 炎・気管支炎 $26.6 \%$, (3)悪性新生物 $13.3 \%$, 非痴呆群 では, (1)悪性新生物 $33.3 \%$, (2)心不全 $16.6 \%$, (3)肺炎・ 気管支炎及び心筋梗塞各 $10.0 \%$ の順であり, 各群間の 死因に相違が認められた。（2）痴呆発現後 3 年以内の 死亡者は, VD 群では60.7\%を占め, DAT 群の $25.0 \%$ に比べて有意に高率であった $(\mathrm{p}<0.01)$.（3）原死因 発症時の痴呆の程度別の死亡頻度では, DAT 群, VD 群共に高度痴呆での死亡が多く認められた（73.3\%, $56.6 \%)$. (4) 原死因発症時の ADL 別の死亡頻度で は, DAT 群, VD 群共重度障害時での死亡が多く認め られ(各80.6\%), 非痴呆群での重度障害での死亡頻度 $50.0 \%$ に比べて有意に高率であった $(\mathrm{p}<0.01)$.

結論：高齢者では, 痴呆の有無や痴呆の種類により 原死因に相違がある事や，VD患者ではDAT 患者に 比べて痴呆発現後比較的早期に死亡しやすい事などが 示唆された。痴呆患者では, 高度痴呆・寝たきり状 態となり死亡するケースが多く認められた。

\section{7. 痴呆患者の ADL 低下をおこす要因}

東大公衆衛生 新野 直明, 小泉 明 浴風会病院内科杉野 正一, 大友 英一

目的：痴呆患者の ADL (日常生活動作)を低下させ る要因について知ることは, 患者のヶアといら面から みて，大きな意義があると考光られる。そこで，われ われは，アルツハイマー型痴呆之脳血管性痴呆の症例 を対象にそその ADLを低下させる要因について調べ
たのでその結果を報告する。

方法・対象：臨床経過と病理所見からアルッハイ マ一型疾呆 (DAT) と診断された 30 例（男 6 例，女 24 例, 平均年齢 $82.8 \pm 8.8$ 歳) と, 脳血管性痴呆之診断さ れた 30 例 (男13例，女17例，平均年齢83.4 4 7.3歳) で ある。これらの症例について, 痴呆発現から死亡まで の経過をカルテなどから調べ，その ADLを低下させ た要因について検討を加光た，ADLは，歩行可能なも のを良好群, 車椅子生活が可能なものを軽度障害群, ベッド上生活が主なものを重度障害群として，3 段階 で評価した。

結果：DAT 群に抬いてADLを低下させる要因と して最も多かったのは損傷・外傷（転倒，骨折，SDH など)で, ADL 低下の $29.7 \%$ これにより起きていた。 2 番目は痴呆に伴う精神症状（意欲低下，性格変化な ど) $24.3 \% ， 3$ 番目は感染症 $16.2 \%$ あった。.VD 群で

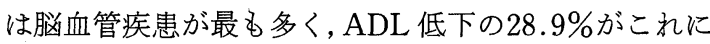
よるものだった。 2 番目は損傷・外傷 $26.3 \% ， 3$ 番目 は痴呆に伴う精神症状 $21.1 \%$ であった。

両群の順位に若干の差はあるものの, 損傷・外傷が 多いという点は共通して抢り, 痴呆患者のケアに括い て十分な注意を払ら必要があると考光られた。

208.ヒト脳底動脈のトーヌスにおょぼす血小板の効 果について

兵庫医大第二内科

垣下 榮三, 若林 一郎, 永井 清保

同法医学 羽竹 勝彦, 菱田 繁

目的：凝固系扝よび血小板の活性化は血管のトーヌ スに関係し，血管病変の原因となり得る。我々はト口 ンビンや血小板が家鬼大動脈を収縮させることを報告 して来た。今回ヒト脳底動脈のトーヌスに拈よぼす血 小板の影響について検討した。

方法：死後24時間以内の七ト脳底動脈を摘出し, Furchgott の方法によりラセン状血管条片を作製し， 収縮槽中で等尺性収縮を観察した。健常ヒトPRPよ りArdlieの方法により血小板浮遊液を作製した。一部 の条件は内膜面をサンドペーパーにて擦過し内皮剝離 標本として用いた。

結果：1）血管を phenylephrine で収縮後トロンビ ンを加えると内皮存在下でのみ拡張作用を示した。 こ の反応は tachyphylaxis を示した.2）血管を同様に収 縮させた後, 血小板浮遊液を加えると内皮存在下では 払張反応を示した。内皮剥離血管では収縮反応を示し 
た。ここに更にトロンビンを加えると内皮の有無に拘 らず一過性の強い収縮を示した．3）血管を Apirase 前処置すると血小板による拡張は抑制された。4）内膜 剥離血管を methysergide 処置すると血小板による収 縮作用は抑制されたが，更にトロンビンを加えて起る 収縮は抑制しなかった，5）BPB や OKY 前処置血小 板を内膜剥離血管に作用させても血管の収縮は抑制さ れたが，更にトロンビンを加えて起す血管収縮反応は 抑制しなかった．6)高齢者の脳底動脈では血小板によ る拡張反応は著明に減弱していた。

考案・結語：ヒト脳底動脈に括いて, 血小板は内皮 依存性の抬張作用を，非依存性の収縮作用を示し，前 者には血小板由来の ADP, ATPが, 後者にはserotonin, thromboxane $\mathrm{A}_{2}\left(\mathrm{TXA}_{2}\right)$ が関与すると考克 られる，血小板が強く活性化されると内皮の有無にか かわらず強い収縮作用を示したが，これは serotonin， $\mathrm{TXA}_{2}$ 以外の物質の関与が推測された。高齢者の血管 では血小板による拡張作用が減弱しており，これは内 膜の障害が関与すると考兄られ，虚血性脳血管障害の 一因となり得る事が示唆された。

\section{9. 脳血管性痴呆, 老年性痴呆に対する塩酸 DIL- AZEP の効果}

\begin{tabular}{|c|c|c|c|c|}
\hline \multicolumn{5}{|c|}{ 大第二内科 } \\
\hline 水野 & 学, & 杤原 & 敏彦, 加古 & 博幸 \\
\hline 加藤 & 伸, & 平田 & 信, 原 & 豊 \\
\hline 藤岡 & 考之, & 岸 & 均, 袖山 & 貴江 \\
\hline 清水 & 隆, & 杉 & 忠男 & \\
\hline
\end{tabular}

目的：我が国に拀いても老年者人口の急増化，また 脳卒中急性期の治療の進歩に伴い脳血管性疾呆 (M.I. D.), 老年性痴呆 (S.D.)の増加は大きな社会問題となっ て扮り対策が忙れている。 今回我々はこれらの症例に 脳血流量増加, 血小板凝集抑制, 赤血球变形能の充進 を主作用とする塩酸 DILAZEP を投与し有効性を比 較検討した。

方法：対象は石井らによる天科法および Hatchinsky score（得点が 9 以上を M.I.D., 4 以下を S.D.）に よって診断した M.I.D. 患者（脳血管性痴呆）15人（男 7 人, 女 8 人, 平均年齢 77.5 歳), S.D. 患者(老年性疾 呆) 12 人（男 4 人，女 8 人，平均年龄 80.3 歳）飞塩酸 DILAZEP $300 \mathrm{mg} /$ day 8 週間投与し精神症状, 神経症 状，日常生活行動に対する効果について検討した。な お M.I.D. 患者は全例に C.V.A. の既往がある。

結果：全般改善度は M.I.D. 群40\%, S.D. 群16.7\%
であった．また層普別改善度より高年齢であり中等度 以上の重症度を示し罹病期間が $2 \sim 3$ 年の症例にも改 善が認められた。症状別改善率は両群共に精神症状, 神経症状, 日常生活行動の順に改善が認められた。特 に M.I.D. 群に括ける精神症状の中等度以上の改善率 は40\%と高い改善率を認め, S.D.群での改善率 $17.7 \%$ より高值を示した。なかでも睡眠障害, 不安, 苦悶, 焦燥, 抑榣症状に高い改善が認められた。神経症状の 改善率は M.I.D. 群13\%, S.D.群 8 \%であり M.I.D.群が 高かった. 日常生活行動の改善率は M.I.D. 群 $7 \%$ であ り S.D. 群では中等度以上の改善は認められなかった。 投与期間中他覚的, 自覚的所見及び生化学検査に異常 は認められなかった。 以上の結果より脳血管性痴呆に 対して塩酸 DILAZEP 投与は有用な効果を期待でき る薬剤の一つと考えられる。

\section{0. 虚血性脳血管障害における血小板活性化に対す るチクロピジンおよびアスピリンの影響}

国立大阪病院循環器科

$$
\begin{aligned}
& \text { 今泉 昌利, 芦田 敬一 } \\
& \text { 三重野正之, 阿部 裕 }
\end{aligned}
$$

目的：虚血性脳血管障害の発症および進展には血小 板の活性化が大きく関与していることは衆知の事実で ある。一方，抗血小板剂はこれらの活性化を拈さ光血 检・塞栓の発生を防止する効果があることが認められ ている，今回，我々は虚血性脳血管障害に拈いて抗血 小板剂であるチクロピジンおよびアスピリンを投与 し, これら作用機序を異とする抗血小板剤が血小板形 態にいかなる変化をもたらすかを電子顕微鏡的に観察 し，検討した。

対象および方法：対象は虚血性脳血管障害のみを有 する25例（I 群）と虚血性脳血管障害に高血圧を合併 する18例(II群), さらに, 虚血性脳血管障害に心房細 動を合併する14例（III群）で，以上の症例より抗血小 板剂や降圧剂を服用していない時期とチクロピジン 200〜300mg またはアスピリン660９90mgを2 週間 以上服用した時期に肘静脈より採血し血小板形態を電 子顕微鏡にて観察した。

成績：虚血性脳血管障害患者に扣ける抗血小板剂投 与前の血小板形態の主なる変化は偽足形成と細胞表面 の褶曲で,さらに, これら変形血小板では濃染顆粒の 減少も観察された。これら変形血小板や濃染顆粒の減 少の割合はIII群, II 群, I 群の順で大であった。しか し, 変形血小板の割合はアスピリン投与前後では変動 
はなかったが，チクロピジン投与後では変形血小板数 の減少がみられた。一方, 変形血小板に抢ける濃染顆 粒の減少はアスピリン, チクロピジンともに投与後で は認められなかった。

結論：チクロピジンやアスピリン投与後活性化血小 板に扔いて濃染顆粒の減少がみられないことはこれら の抗血小板剂により放出反応が抑えられていることを 形態学的に示唆するものである。一方，チクロピジン はアスピリンに比較して血小板の変形を抑兄正常形態 を保持する働きがあることも確認出来た.

\section{1. 抗血小板療法下（チクロピジン, アスピリン） での脳血栓症再発例の検討一非再発例との比較}

都老人医療センター神経内科 大川 義弘, 葛原 茂樹

目的：脳血栓症の Second Prevention として，アス ピリン，チクロピジンといった抗血小板剤療法 (AP) が行われているが, AP 下でも, 再発をきたす例をよく 久かける。今回かかる例が, 非再発例に比較し, 背景 因子が異なるのかどうかを検討した。

対象と方法：AP下の外来患者（一部は当院退院後 他院へ転院したものも含む.) の中で非再発例 $\mathrm{A}$ 群 (43 例, 男 30 例, 女 13 例, 平均年齢 70.3 歳), 再発例 $B$ 群 (20 例, 男15例, 女 5 例, 平均年齢70.2歳)を対象とした。 両群で, AP 開始となった脳血栓症より以前の脳卒中 の回数, 同脳血栓症発症時の症状, CT, 脳血管写, リ スクファクターなどについて検討した。 なお $\mathrm{A}$ 群では AP 開始後の経過観察の期間は 6 力月 95力月（平均 38.5力月）であり， B 群では $\mathrm{AP}$ 開始後再発までの期 間は 2 日〜 93 カ月（平均 18.8 月）であった。

結果：1）両群間で性・年齢に差は認めず，2）AP 開 始となった脳血栓症より前の脳卒中の回数についてみ ると, $\mathrm{A}$ 群では延で 9 回少なくとも 1 回以上の発作例 は 9 例で 2 回以上の発作も認めたものは 0 例であるの に比し B 群では，それぞれ $8,5 ， 3$ とすでに発作を くりか劣している例が多かった。 3）AP開始となった 時点での CTをみると, A 群 (40例) では深部単発が 17例と最も多く，ついで皮質技系梗塞11例，所見なし 6 例となって和り一方 B 群 (18例) では深部多発が 7 例，皮質技系が 4 例であり，B 群で深部梗塞多発が多 い傾向を示した，4）脳血管写では動脈硬化度を内頝 系, 椎骨系について, 軽, 中, 高度にわけて検討した が，A，B 群間で特に差を認めなかった，5）その他の 因子でも両群間で差を認めなかった。
結論：再発例では，AP 開始となった脳血栓症より 以前に，脳卒中を执こしていることが多く，それらは $\mathrm{CT}$ 上は, 深部梗塞多発としてあらわれていた。脳血管 写では再発例, 非再発例に差を認めなかった。

212. 脳梗塞急性期および慢性期における血小板凝集 能の变化一インピーダンス法による検討

岩手医大神経内科

木村 文祥, 田村 乾一, 木村 宗孝

鈴木一，東儀 英夫

目的：脳梗塞 (血检, 塞栓) 急性期 $(<1 \mathrm{~W})$, 慢性 期 $(>4 \mathrm{~W})$ に打ける血小板凝集能の变化を電気的イン ピーダンス法（全血，PRP）により追跡し対照と比較 検討した。

対象と方法：対象は脳梗塞（ $n=59 ）$, 対照（ $n=131$ 例）である。いずれも抗凝固剂，ステロイド，抗血小 板剂は使用していない。検体は肘静脈より採血し， $3.8 \%$ クエン酸ソーダと血液を $1 ： 9$ の割合に混合し たクエン酸加全血と150G 5 分間室温で遠心後得た Citrated Platelet Rich Plasma を使用した。

結果：脳血栓の全血凝集能は急性期に対照例上り低 值を示し, 慢性期へ移行するに従い上昇し対照例より も高值の傾向を示した。脳血栓の PRP 凝集能は急性 期に対照例より有意の低值を示し，慢性期へ移行する に従い上昇したが対照例よりも有意に低值を示した。 脳塞栓の全血凝集能は急性期, 慢性期ともに対照例よ りも高値の傾向を示し, 慢性期に移行するに従い上昇 を示した。脳塞栓の PRP 凝集能は急性期に対照例よ りも低值を示し, 慢性期へ移行するに従い上昇し対照 例よりも高值を示した。

全血と PRP 凝集能值の差を比較すると, 対照例で は全血凝集能 $<\mathrm{PRP}$ 凝集能であった。脳梗塞急性期お よび慢性期では全血凝集能 $>$ PRP 凝集能の例が有意 に多かった。

\section{3. 血小板凝集能測定における比濁法およびイン ピーダンス法の比較検討}

岩手医大神経内科

田村 乾一, 木村 文祥, 木村 宗孝

鈴木一，東儀 英夫

目的：最近開発された，全血のままで測定可能なイ ンピーダンス法（I 法）による血小板凝集能を従来か らの比濁法 (OD 法) と比較検討した。

方法：健康成人・脳血栓急性期例を対象として，1/9 
容クエン酸加血を用いて，全血はそのますで PRPは 150G，5 分間の遠沈で作成した。 I 法は Chrono Log 社の Whde-blood Aggregometer Model 540, OD 法 は NBS 社 Hematracer VI を使用した。凝集惹起物質 には終濃度 $2 \mu \mathrm{g} / \mathrm{ml}$ のコラーゲンを使用し, I 法は, コ ラーゲン添加後 6 分の抵抗値 $(\Omega)$ で, OD 法は, 最大 凝集率（\%) で表わした。

結果：I. 正常例での検討 (1)全血を用いた I 法 (全 血・I 法)による凝集能とOD 法による凝集能との間 の相関は弱かったが, 同一例で PRPを用いた I 法 (PRP・I 法) に上る凝集能と OD 法による凝集能を比 較すると有意ではないが，両者の間の相関は強くなっ た. (2) OD 法では，血小板数による凝集能の変化はほ とんど認めなかったが，PRP および全血・I 法では， 血小板数の増加とともに凝集能が増加する傾向をわず かに認めた。 (3) OD法では, ヘマトクリット值 (Ht.) の増加とともに，わずかに凝集能が低下する傾向が あった，PRP・I 法では，凝集能は Ht，に影響されな かった。全血・I 法では，Ht 20\%以上になると Ht の 増加とともに凝集能が低下した。 II. 脳血栓急性期例 での検討 脳血栓急性期例では, Ht の増加とともに凝 集能が増加する傾向を認め, その傾向は, OD 法に比し て, 全血・I 法で強かった。

まとめ：正常例では, 全血・I 法による凝集能は, とくに Ht の影響が大きく, OD 法の結果と直ちに比較 できない.どちらの方法が生体内の現象をよく反映し ているのか梳不明であるが, 脳血栓急性期例では正常 例と異なる Ht の凝集能への影響が示唆され, 全血・I 法は OD法では得られぬ知見をもたらす可能性があ る。

\section{4. アスピリン少量投与 $(40 \mathrm{mg} /$ 日) およびチクロ ビチン投与の血小板凝集能に対する効果の比較検討} 岩手医大神経内科

$$
\begin{aligned}
& \text { 木村 宗孝, 田村 乾一, 木村 文祥 } \\
& \text { 鈴木 一, 東儀 英夫 }
\end{aligned}
$$

脳梗塞後遺症の症例36例に対し, アスピリン $40 \mathrm{mg} /$ 日投与群19例, チクロピジン $200 \mathrm{mg} /$ 日投与群 17 例に分 け, 投与前, 投与 1 週後, 4 週後の electric aggregometer による全血血小板凝集能, 比濁法による $\mathrm{PRP}$ 凝集能, 血清 $\mathrm{TxB}_{2}$ 6-ケト- $\mathrm{PGF}_{2}$ を測定した。凝 集惹起物質には, コラーゲン $(2 \mu \mathrm{g} / \mathrm{ml}), \operatorname{ADP}(10 \mu \mathrm{M})$, エピネフリン $(10 \mu \mathrm{M})$ を用いた。比濁法では最大凝集 に抢ける透光度 (\%) 和よび凝集曲線の形を検討した。
結果としては, アスピリン群では, 全血凝集反応, $\mathrm{PRP}$ 凝集反応共に有意に低下傾向を示したが, チクロ ピジン群では, 全血凝集反応, PRP 凝集反応共 ADP 凝集のみ有意の低下傾向を示した。 また血清 $\mathrm{TxB}_{2}$ 6-ケトーPGF $\alpha$ は, アスピリン群では投与後に著しい 低下傾向を示したが，チクロピジン群では $\mathrm{TxB}_{2}$ がわ ずかに有意の上昇傾向を示した。これらより，アスピ リンの血小板凝集抑制作用は, たとえ $40 \mathrm{mg} /$ 日の少量 投与でも,チクロピジン $200 \mathrm{mg} /$ 日よりもはるかに強い と思われる。しかし血清 $\mathrm{TxB}_{2}$ とともに6-ケト- $\mathrm{PGF}_{1}$ $\alpha$ も著しい低下を示すため, 少量投与でもアスピリン ジレンマは解決できたとはまだ言えない。血小板凝集 能の測定にさいしては, 量的指標を用いる限りでは, electric aggregometer, 比濁法共にほぼ同じ結果を示 した. しかし, electric aggregometer は全血の状態で 血小板凝集能を測定しうるといら利点はあるが, 比濁 法のように二次凝集や解離 (disaggregation)を観察し えず，しかもこれがょり重要な指標となりらるため, ここに本法の限界があった。

\section{5. 虚血脳の生化学的変化に対するオピオイドペプ チド（dynorphin）の影響}

岡山大第三内科

黒田 広生, 高山 晴彦, 太田 善介 同脳代謝研究施設 小川 紀雄

目的：内因性オピオイドペプチドである dynorphin の脳梗塞モデルに対する著しい延命効果が注目されて いるが，その作用機序の詳細は不明である。今回, 我々 はこの点を明らかにするため虚血脳における生化学的 変化に与光る dynorphin の影響について検討した。

対象と方法：対象は 48 匹の雄ネコ(3〜 $5 \mathrm{~kg})$ で, コ ントロール群, 脳梗塞群, dynorphin 処置脳梗塞群の 3 群に分けた. 脳梗塞モデルの作製は O’Briens の方法に 従って経眼窩的に一側中大脳動脈結紮により作製し た. 脳の摘出はモデル作製 7 時間後に行い, dynorphin 投与群では脳摘出 1 時間前に dynorphin $(2 \mathrm{mg} / \mathrm{kg})$ を 腹腔内に投与した。摘出脳（小脳，脳幹は除く）は左 右の皮質, 皮質下の計 4 部位に分けたのち, 通常の方 法に従い $\mathrm{P}_{2}$ 分画(受容体結合実験用)，粗シナプトゾー ム分画（取り込み実験用）を得た。受容体結合実験で は放射性リガンドとして ${ }^{3} \mathrm{H}$-ethylketocyclazocine （EKC）を用い，飽和曲線を作製したのち Scatchard 分 析を行った。取り込及実験は Weinbergerらの方法に 準じて行い，放射性リガンドとして ${ }^{3} \mathrm{H}$-dopamine, 
${ }^{3} \mathrm{H}$-GABA 使用した。

結果：脳梗塞群に拈いて, 虚血側大脳皮質の $\mathrm{EKC}$ 受容体結合親和性が非虚血側括よびュントロール群の 同部位に比し有意に低下 $(\mathrm{p}<0.01)$ 乙, dopamine 取 り込みでは非虚血側大脳皮質での $\mathrm{Km}$ 值が有意に減 少 $(\mathrm{p}<0.001)$ 乙,$V \max$ 值は有意な増加 $(\mathrm{p}<0.05)$ を示した.しかし, dynorphin 処置脳梗塞群では上記の 変化は認められず，いずれもコントロール群と有意差 はなかった。 GABA 取り込みは脳虚血や dynorphin 投与による影響を全く受けなかった。

考察：虚血脳に打けるオピオイド受容体結合および dopamine 取り込みの変化に対する dynorphin の有意 な正常化作用が，脳梗塞モデルに対するこのペプチド の延命効果の基礎的根拠の 1 つとなる可能性が示唆さ れた。

\section{6. 皮膚インピーダンスの関する研究}

聖マリアンナ医大第二内科

杉原浩, 反町比呂子, 明石のぞみ 米山 公啓, 佐藤 忠一, 清水 亨 須階 二朗

目的：各年代層正常人男女につき, 皮膚の交流電気 抵抗（インピーダンス）を測定し，年齢的変化の指標 たり得るかを検討した。

装置と方法：当教室がフクダ電子（株）の協力を得 て開発した生体インピーダンス測定装置を用いた。測 定には $3 \mathrm{~Hz}$ を用い, 測定電流は実効値 $10 \mu \mathrm{A}$ とした。 イ ンピーダンスの絶対值は, $\times 1, \times 10, \times 100$ の 3 レンジ を切りかえ, $0.5 \sim 530 \mathrm{~K} \Omega$ の測定が可能である. 位相角 は 5 度以下から 90 度までの測定が可能である。測定用 電極は, 塩化銀処理を行った幅 $1.0 \mathrm{~cm}$, 長さ $3.5 \mathrm{~cm}$ の銀 板 2 枚を, 中心間距離 $2 \mathrm{~cm}$ でデルリン製の支持台に並 べたものを用いた，測定時には，電極表面を生理食塩 水に浸してから, 皮膚面に接触させて測定した。測定 個所は, 頭部, 胸部, 腹部, 四肢の前面18力所, 背面 14 力所の計 32 力所である. 対象は 24 歳 23 歳の正常人 男女 28 名である。環境条件として, 気温, 湿度, 気圧, インピーダンス測定個所の体表面温度を同時に測定し た.

結果抢よび考案：1）皮膚インピーダンスの絶対值 は個体間に差が大きく，比較的測定値が安定した上腕 屈側を基準値として，体表各部位をこれに対する相対 值として検討した。 2) 皮膚インピーダンスは, 部位差 を有し顔は低く，上肢，下肢は高く，体幹が中間值を
とる傾向がみられ，皮膚インピーダンスの分布には一 定のパターンがあることが示唆された．3）皮膚イン ピーダンス特に絶対値と加齢との関係は，測定が夏期 であった関係もあり，日焼けの影響と考えられる例も 含まれ，今回は明確な結論は見出せなかった。今後症 例をかさね検討したい。

\section{7. 結合組織代謝からみた老化 慶大衛生学公衆衛生学}

岡崎 勲, 小林友美子

目的：線維化指標として血清 type III procollagen peptide (P-III-P) が注目され，また基底膜成分の $1 つ$ である laminin についても血清中の濃度を測定するこ とができるようになってきた。そこで私共は，尿中 hydroxyproline (HOP) の基礎排泄量を測定すると共 に, 血清 P-III-P，血清 laminin 值を測定し，老年者の 結合組織代謝の生理的変化を検討したので報告する.

方法：65歳以上の老年者 17 名を含む成人 68 名（男子 31名，女子 37 名）について検索した。 68名を10歳間隔 で年代別にして検討した。すなわち，20歳代 6 名，30 歳代12名，40歳代15名，50歳代14名，60歳代12名，70 歳代 9 名であった. 血清 P-III-P 值掞よび血清 laminin 值はへキスト社より入手した RIA キットを使用した。 すなわち Rohde ら (1979) の原法に従い，血清を 4 段 階に稀哷し，抗原抗体反応の inhibition curve からの $50 \%$ interception 值から各検体の血清値を求めた。尿 中 HOP の基礎排泄量は，食事由来の HOP を排除す る著者らの採尿方法（第56回日本衛生学会総会発表, 昭和61年 3 月）により，Kivirikko and Prockop らの 方法により測定し, creatinine 比で算出した.

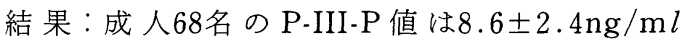
$($ mean $\pm S D)$ で, 男 $9.1 \pm 2.6(\mathrm{n}=31)$, 女8.2 $2.0(\mathrm{n}=$ 37) と男子は僅か高かったが有意差はみられなかった。 20歳代から40歳代まではその平均值は7.6から8.1ng/ $\mathrm{m} l$ であったが, 50 歳代 $8.6 \pm 1.8,60$ 歳代 $8.7 \pm 1.7,70$ 歳代 $10.8 \pm 2.3$ と 50 歳代より僅ずつ血清値は高かった。 しかし，有意差まではみられなかった。血清ラミニン 值についてもほぼ同様の成績であった。一方，尿中 HOP の基礎排泄量は, 30 歳代 $4.1 \pm 0.7,40$ 歳代, $5.8 \pm$ $0.7,50$ 歳代 $4.6 \pm 2.2,60$ 歳代 $4.0 \pm 0.7,70$ 歳代 $3.2 \pm$ 0.7 と 60 歳代および70歳代で低下していた。 今回の私共 の成績では, 老年者では, 結合組織の産生は不変ない し僅か増加の傾向で，分解は低下している傾向を観察 した。ささらに老年者の数を増し，男女別に検討して， 
その成績を報告したい。

\section{8. 組織の加齢進展機序に及ぼす nonenzymatic} glycation

神戸大第二内科

前田裕一郎, 秦 文彦, 北村 嘉章

西本 茂樹, 松本真一郎, 畑中 裕司

老粐 宗忠, 馬場 茂明

目的: $\mathrm{HbA}_{1}$ は Hemoglobin $(\mathrm{Hb})$ と glucose との nonenzymatic glycation，すなわち Maillard 反応に より生成される。一方我々は蛋白の lysine 残基の $\varepsilon$ ーアミノ基に glucose の結合した fructoselysine (Amadori 化合物)を酸性加水分解し, 生ずる furosine を組織蛋白の nonenzymatic glycation の指標として 測定してきた。今回，ラットの加齢に伴う組織蛋白の nonenzymatic glycation の変動を furosine 測定を用 いて検討した.

方法：4 週齢から120週齢まで種々の週齢の wistar 系雄性ラット大動脈 $(\mathrm{Ao})$ 及び坐骨神経 $(\mathrm{N})$ に $6 \mathrm{~N} \mathrm{HCl}$ を加光, 30 時間の加水分解を行った. 蒸発乾固の後, 蒸留水で再溶解し, Millipore filter 通して高速液体 クロマトグラフィー(HPLC) 用の検体とした。 カラム には ODS-120T, 移動相には $7 \mathrm{mMH}_{3} \mathrm{PO}_{4}$ を使用し, UV280nm 及び254nm で HPLCを用いて furosine を 分析した。 furosine 值はクロマトグラム上, 内部標準 としての tyrosine に対する furosineのピーク面積比 (furosine/tyrosine $\times 100(\%)$ ) で示した.

結果： $\mathrm{HbA}_{1}$ は 4 週齢では低值を示したが，それ以 降の週齢では各週歯間に有意の差を示さなかった。一 方, Ao 及びNの furosine 值は 4 週龄では測定感度以 下であったが，週齢の増加と共に上昇し，50週龄では

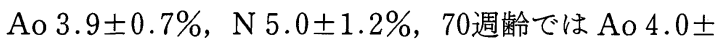
$0.8 \%, N 5.0 \pm 0.7 \%$ とピークを示し，その後 90 週歯, 120 週齢では低下傾向を示し，120週齢ではAo 2.5土 $0.3 \% ， \mathrm{~N} 4.2 \pm 1.0 \%$ と50及び70週龄に比較して有意 に低下した. Maillard反応の early productsである Amadori 化合物が加齢と共に増加し，ある時点より加 齢の進展に伴って減少傾向を示したことは，生体にお いても加龄によって early productsから late products Maillarad 反応が進展している可能性が考党 られ，老化進展機序と Maillard 反応である nonenzymatic glycation との関係を考兵る上で重要な事実 と考光られた。
220. 痴呆脳におけるカテプシン D 活性の変化とカ テプシン D の脳内線維性蛋白に対する影響

阪大精神医学

鈴木 英夫，武田 雅俊，多田 國利

播口 之朗, 西村 健

目的：アルッハイマー型老年痴呆 (SDAT) 患者脳 の神経細胞, とくに神経原線維变化をきたした神経細 胞の核周囲には, 多数のライソン゙ームが観察される. 今回，われわれは，ライソゾーム内酵素の1つであり， 酸性プロテアーゼである Cathepsin Dについて，その 活性が SDAT 脳内で変化していることを想定して検 討を行なった。

材料・方法：(1)人剖検脳材料：SDAT 脳 2 例之脳血 管性痴呆脳 1 例は，いずれも死亡約 5 時間後の剖検に て得られた。対照脳は年齢を合わせた注济同条件の司 法解剖 3 例を用いた。 (2) Cathepsin D 活性の測定 : Marks らの方法に従い, 脳各部位より Cathepsin D 分 画を調整し, Sera らの方法によって Cathepsin D 活性 を測定した。 (3) Cathepsin Dによる neurofilament (nf) 蛋白の分解：nf triplet 蛋白 $(200 \mathrm{~K}, 160 \mathrm{~K}, 68 \mathrm{~K})$ をTokutake らの方法にほぼ準じて分離精製し，各々 の triplet蛋白に牛脾臓より抽出したCathepsin D $(0.08 \mathrm{mg} / \mathrm{V})$ を作用させて，分解産物をポリアクリル アミドゲル電気泳動（PAGE）を用いて調べた。

結果：(1)脳内の Cathepsin D 活性 : Cathepsin D 活 性は, SDAT 脳各部位に括いて, 脳血管性痴呆, 対照 脳に比べて有意に高く，とくに NFC の発現頻度の高 い海馬に掠いて，より高值を示した。 ライソゾーム内 の他の酵素の活性を知るために，ライソゾームのマー カ一酵素として知られている $\beta$-glucuronidase につい ても, その活性を調べたが, 変化は認められず, SDAT 脳に打ける Cathepsin D 活性上昇は，NFCなどの神 経細胞変性の発現に何らかの形で関与している可能性 が示唆された。 (2) Cathepsin D によるnf 蛋白の分解： nf triplet 蛋白はいずれもCathepsin D の基質となり, 各 triplet 蛋白の分解産物と考光られる蛋白バンドが 確認された。このことから，異常な線維構造の集積で ある NFC の形成に Cathepsin D などの protease が 関与している可能性が示唆された。

221. ゴナドトロピン系のヒスタミン性調節と老化 阪大精神医学

Ramon Cacabelos，新川 久義 多田 国利, 播口 之朗, 西村健 
同産婦人科 三宅 㑆

目的：我々はこれまでに視床下部一下垂体系 (Hhs) の histamine (HA) 值が加㱓により影響を受け，視床 下部後部および海馬で減少し，下垂体後葉および正中 隆起で増加することを報告してきた。また，周知のご とくゴナドトロピン系も加齢により影響を受ける、今 回，我々はHA がゴナドトロピン系に対して神経調節 機能を有している可能性およびゴナドトロピン系調節 因子としての HA と加齢との関係を検討するために 以下の実験をおこなった。

方法: 雄雌, 各 $5 \sim 6$ 匹の Young ( 2 力月), Adult (12カ月), Old(30カ月)の Wistar ラットを用いて HA (0.6mmol $/ \mathrm{kg})$, Mepyramine ( $\mathrm{H}-1$ antagonist ; Mep ; $0.3 \mathrm{mmol} / \mathrm{kg}$ ) および Famotidine ( $\mathrm{H}-2$ antagonist; Fam $; 0.4 \mathrm{mmol} / \mathrm{kg}$ )を腹腔内投与し，血中および Hhs （視床下部前部，視床下部後部，正中隆起，神経性下垂 体，腺性下垂体）中の黄体形成ホルモン放出ホルモン (LHRH) および黄体形成ホルモン（LH）を測定した。 また，LHRH $10 \mu \mathrm{g}$ とあわせて HA, Mep および Fam を投与した時の LH 放出を同様部位で調べた。 LHRH 执よびLHはRIA によって測定した。

結果: 無処置の血中 LH 值はOld 雄ラットより Old 雌ラットで高值であった. HA は Young ラットの 視床下部後部で LHRH 值を著明に増加した。 また，

HA LHRH 投与による血中への LH 放出を減少 し，Mepと Famはこの効果を抑制した。HA は Young ラットの視床下部前部の LHRH 值に影響を与 えなかった。しかし, Old ラットにおいては視床下部前 部で HAによる LHRH 増加を認め, Mep は部分的に Fam は完全にこの増加反応を抑制した。

考察：以上の結果から HA は主にH-2リ七プター を介してゴナドトロピン系の調節機能を有している可 能性が示唆された．加齢によってこの機能の部分的障 害が生じ，この障害が Hhs 系の性腺刺激ホルモンの移 送障害や LHRH による LH 合成および放出の機能障 害を引き起こしている可能性が考兄られた。

222. 加齡に伴う脳内ヒスタミンおよびバソプレッシ ンの変化

阪大精神医学

新川 久義, Rảmon Cacabelos.

山下 正，播口 之朗，西村 健

目的：Vasopressin (VP) は学習, 記憶などの精神 機能に関係すると考えられている。㐬え，我々はこれ
までに Histamine (HA)が VP の neuromodulator と して機能していることを明かにしてきた。今回，我々 は生後 3 週から 32 カおでのラット脳内の VPと HA を測定することにより，VPの局所的增減と加齢の関 係を調べるとともに，VP 調節因子としての HA が加 齢に関与する可能性を検討しようとした。

方法：Infant ( 3 週), Young ( 3 力月), Adult (14 カ月), Old (28～32 カ月) の Wistar rats（各齢ともに 雌 6 匹，雄 6 匹）を用いた。ラットの脳から視床下部 前部, 視床下部後部, 正中隆起, 神経性下垂体, 腺性 下垂体抢よび海馬の 6 カ所を解剖分離した。VPは, 我々が作製した抗体を用いた RIAによって測定した。 HA は, fluorometric detectionを用いた高速液体クロ マトグラフィーにより，大和谷らの方法で測定した。

結果：VPは加齢に伴って神経性下垂体抢よび正中 隆起で増加し, その他の部位では減少した. HA は加齢 に伴って神経性下垂体, 正中隆起掞よび視床下部前部 で増加し,その他の部位では減少した。特にVP と HA の減少の著明な部位は海馬であった。

考察：VP の循環系への放出部位である神経性下垂 体と, VP が ACTH 拉よび他の下垂体前葉ホルモンの 分泌調節に係わっていると考兄られている正中隆起で VP が加歯により増加したことは, 神経内分泌に係わ る部位での VP貯留, 即ちVP の放出障害が加齢に よって生じていることを示唆するＶVPの合成細胞の 存在する視床下部前部やVP の投射を受ける海馬やそ の他の部位で加齢により減少したことは，VP の合成 障害および精神機能と係わる部位への VP 移送の障害 が加齢に伴って生じていることを示唆する。 また，HA がVP と類似の変化パターンを示したことは，HA が VP の合成, 移送抢よび放出などの機能に対して神経 調節物質として係わっている可能性を支持する.

\section{3. 超音波血流量測定法による高齢者動脈硬化およ び老人性痴呆の䅡動脈血流量評価}

金沢医大老年病科

関本 博, 松本 正幸, 中野 利美
堀部 尚久, 鈴木 俊之, 森本 悦司
林 光義, 石川 紀子, 土屋
生垣 博行

目的：高齢者が増えつつある今日，動脈硬化など老 人性変化の際にての脳循環動態評価は重要であり, 乙 かも老人に扔いては負担の少ない非観血的な検索が望 まれる，今回我々は頝動脈血流量測定用に作成された 
超音波装置を用い，高齢者に捛ける䅡動脈血流量を計 測し若年健常者群と対比検討した。

対象と方法：頚動脈血流量計測には，3つの振動子 を装備し，血管に対する超音波入射及び反射角に影響 されずに絶対流速を測定できる血流速測定装置にリニ ア電子スキャンを複合せる超音波血流量測定装置（ア ロカ社製 SSD-980）を用いた。

対象：(1) 若年健常者群 (5 例, 平均25.4歳)，（2） 超音波断層エコー法にて動脈硬化が強く，長谷川式知 能評価スケールで正常であった群 (4 例, 平均83歳), （3）長谷川式スケールで痴呆と診断された群（3 例, 平均86歳）につき, 左右総䅡動脈の平均流量, 平均流 速, 平均血管径を安静仰臥位にて計測した。

結果：(1) 左右総䅡動脈平均血流量は, 若年健常者 群では, 右 $8.47 \pm 0.75 \mathrm{ml} / \mathrm{s}$, 左 $7.77 \pm 0.75 \mathrm{ml} / \mathrm{s}$ で高齢 者動脈硬化群 (右 $3.83 \pm 0.50 \mathrm{~m} l / \mathrm{s}$, 左 $3.85 \pm 0.46 \mathrm{~m} l$ ) s) 及び痴呆群 (右 $2.79 \pm 0.93 \mathrm{ml} / \mathrm{s}$, 左 $2.90 \pm 0.81 \mathrm{ml}$ ) s）は若年健常者に比し左右平均値で，53\%および $65 \%$ 低下を示した。（2）高齢者動脈硬化群, 疾呆群では, 若年健常者に比し平均流速の低下か示され $(8.01 \mathrm{~cm} /$ $\mathrm{s}, 7.31 \mathrm{~cm} / \mathrm{s}$, VS $20.51 \mathrm{~cm} / \mathrm{s})$, 各々, 若年健常者群 との間に有意差を認めた $(\mathrm{p}<0.005)$ ，血管径は，各群 間で有意差を示さず，加齢による血管径の変化の少な いことが示唆された。（3）痴呆群では，高齢者動脈硬 化群に比し, 平均頝動脈血流量が $26 \%$ 低下を示した。

考察：今回の検討では数に制限があったものの，健 常者群と動脈硬化群, 痴呆群の間に血流量及び流速に 有意な差を認めた。平均血管径は有意差がなかったが, 高齢者でやや増大傾向が示された。今回検討した高齢 者群にて䅡動脈血流量低下の要因として, 主に血流速 度の低下が示され，これは脳動脈血流抵抗の増加を示 すと判断された。

\section{4. 超音波ドプラー法（QFM-1000）による総䅡動脈 血流量の加齢变化}

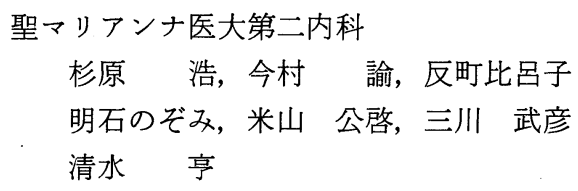

目的：超音波定量的血流量測定装置 (QFM) は，総 頝動脈血流量を正確かつ非侵襲的に測定可能であり, 総頝動脈血流量は, 脳循環血流量をかなり良く反映す るものである. 今回我々は, 入院ドック症例を中心に 自覚症状, 理学的所見抒よび臨床検查所見に異常をみ
とめない正常人において，QFM の測定を行い，各年代 に抢ける測定值から，脳循環血流量の加齢变化を検討 した。

対象及び方法：対象は当院にドック入院した 30 歳代 から70歳代までの79例と, 当科の医師を含む 20 歳代の 正常人18例の計97例である. 総頝動脈血流量は, 超音 波定量的血流量測定装置 (QFM-1000)を用い, 安静仰 臥位で左右総頚動脈で 5 回づつ測定し血流量（以下 $\mathrm{F}$ ), 血流速度 (以下 $\mathrm{V}$ ), 血管内径 (以下 D) を求め最 大値と最小值を除く 3 回の測定値の平均を測定値とし た。

結果：1）20歳代から70歳代の各年代とも F, V, D に沶いて左右差はなかった。 2）F は20歳代から60歳代 まで8.9 8.0 $(\mathrm{ml} / \mathrm{sec})$ とやや低下するが変化は少く, 70 歳代は 6.5 と低下を認めた。また年齢との間に負の相 関をみとめた。 3) V は20歳代 $22(\mathrm{~cm} / \mathrm{sec})$ から 70 歳代 は $14 / \mathrm{cm} / \mathrm{sec}$ ) と加齢に伴い低下し, 年齢との間に負の 相関をみとめた。 4) D は20歳代7.0 (mm)で70歳代は 7.6 と加齢に伴い増加した. 年齢との間に正の相関をみ とめた。 5）平均動脈圧と F, V , D との間には相関は なかった。

考案：局所脳循環血流量の Melamed らの報告から も加齢により脳循環血流量は低下するとされており， QFM の総䅡動脈血流量による今回の検討によっても 加齢により脳循環血流量が低下寸ることがとらえられ た.

225.ラット培養血管平滑筋細胞のプロスタグランジ ントロンボキサン産生におよぼす継代培養の影響 東北大第二内科

竹内 和久, 阿部 圭志, 佐藤 牧人 保嶋実, 尾股健, 吉永馨

目的：血管平滑筋プロスタグランジン $(\mathrm{PG})$ ・トロ ンボキサン (TX) 産生の加齢による影響を検討するた め, ラット腸間膜動脈中膜平滑筋細胞を培養して, こ の培養細胞の継代培養（in vitro aging）による PG・ TX 産生の変化について調べた.

方法：Sprague-Dawley ratの腸間膜動脈より酵素 法にて中膜平滑筇細胞を単離し培養した。継代培養は トリプシン処理により実施し第56代（継代培養約 1 カ 年)までおこなった。実験は confluentとなった細胞を 用い, MEM 単独ないしアラキドン酸 (AA， $5 \mu \mathrm{M}$ ), カルシウムイオノフォア $\mathrm{A} 231872 \mu \mathrm{M}$ ，バゾプレシン 
(VP $10^{-7} \mathrm{M}$ ) \pm 1 -desamino-8-arginine VP (dDAVP, $10^{-7} \sim 10^{-5} \mathrm{M}$ ) 拉よびアンジオテンシン II (AII $10^{-7}$ M) $\pm{ }^{1}$ Sar ${ }^{8}$ Ile-AII $\left(10^{-6} \sim 10^{-4} \mathrm{M}\right)$ と30分間インキュ ベートし，培地中に放出された $\mathrm{PGE}_{2}, \mathrm{PGF}_{2} \alpha, 6$-keto$\mathrm{PGF}_{1} \alpha$ ( $\mathrm{PGI}_{2}$ 代謝物) および $\mathrm{TXB}_{2}\left(\mathrm{TXA}_{2}\right.$ 代謝物) をラジオイムノアッセイ法にて測定した。細胞蛋白は Lowry 法にて測定した。

結果: 各 PG 産生基礎值は6-keto- $\mathrm{PGF}_{1} \gg \mathrm{PGF}_{2}$ $\alpha>\mathrm{TXB}_{2}, \mathrm{PGE}_{2}$ の順に大きく，主要な PGは6-keto$\mathrm{PGF}_{1} \alpha$ であった。継代培養により各 $\mathrm{PG}$ の産生基礎 值, 並びに AA，A23187，VP およびAIIによる PG 産 生刺激は減少したが各 PGの産生順位に影響はみられ なかった。継代培養による $\mathrm{TXB}_{2}$ 産生増加はなかっ

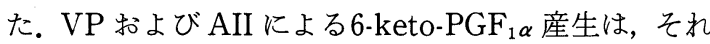
ぞれのアナログにより濃度依存性に抑制された。VP 扣よびAII による6-keto-PGF $\alpha$ 産生刺激は第 7 代培 養細胞以降急激に減少したが, AA 打よび A23187によ る産生は比較的よく保たれた。

結論：ラット培養血管平滑筋細胞のin vitroの aging では各 PG の産生の比率に変化はない，ホルモ ンに特異的な PG 産生を検討する際には，レセプター の性状の変質を考慮し, 約 10 代以内の継代培養細胞の 使用が萀められる。

226. マウス肝グルタチオン $\mathrm{S} ト$ ランスフェレース 活性の加齢による变化

都老人総合研究所臨床第一生理

$$
\text { 木谷 健一, 金井 節子, C.M. Carrillo }
$$

C57Black 雌マウスを用い，若齢 ( 9 月齢) 老齢 (27 月齢) 2 群について, 肝内グルタチオン $(\mathrm{G})$ 濃度, 抒 よびグルタチオン Sトランスフェレース (GST) 活性 を 5 種の異なった基質を用いて比較した。 また無蛋白 食 1 週間投与，さらに正常食再投与 9 日迄，間隔をあ けてマウス群と順次と殺し，上記のパラメーターを比 較した。

対照群（正常食 2 週）においては $\mathrm{G}$ 濃度は両月齢群 で有意差なく，GST活性も1-chloro-2,4dinitrobenzene (CDNB), benzalacetone (trans-4phenyl-3-buten-2-one, $\mathrm{PBO}$ ), sulfo-bromophthalein (BSP), styrene oxide (STOX)，の 4 種の基質に対 する GST 活性は有意差を示さなかった。これに対し， 1,2-dichloro-4-nitrobenzene (DCNB) に対する活性は 若齢群に比し老齢群で有意に低かった。
1 週間の無蛋白食投与により, 両群とも全てのパラ メーターは有意に低下したが，両月齢群の值は全て老 齢群で有意に低かった。正常食再投与 $2 \sim 3$ 日目に若 齢群では 5 種の活性は全て対照値より有意に高くなっ た (overshooting) のに対し, 老齢群では対照值に比 しな扮有意に低い值に留まった，G 濃度は両群とも正 常食 2 日目に注湆対照值に復し, overshootはみられ なかった。両群とも全ての活性は正常食 $5 \sim 9$ 日によ り正常化した。

肝 G 郝よび, GST 活性は, 多種の内因性, 外因性物 質の解毒に極めて重要な働きをしている。従来雄ラッ 卜を用いた研究でこの機能が加齢と共に急速に低下す るという報告が多いが，我々の結果はそれを否定し， optimal な生活環境では月齢差は極めて少ないことを 示唆する。加齢の影響は無蛋白食など, optimal な生活 環境が破たんした場合著明に顕在化すると思われる。

\section{7. 加齢と赤血球ソルビトール} 和歌山医大紀北分院内科

船迫 真人, 寒川 明宣, 小林尚
阪上 良行, 大畑 雅洋

目的：糖尿病 (DM) は動脈硬化を促進させるが，そ の因子として血小板凝集能の亢進, 高脂血症, グリコ シル化蛋白等の他に，糖尿病性神経障害の原因とされ ているソルビトール蓄積も動脈硬化促進の要因である 可能性がある。一方加齢と共に耐糖能は低下し, 動脈 硬化が進展する。そこで DM で増加するソルビトール を加齢という観点から考察し, 組織ソルビトールレベ ルを反映するとされる赤血球ソルビトールを測定し， その意義を探った。

材料及び方法：実験的 DM の材料としては STZ 投 与 rat の洗滌赤血球を用い，臨床材料としては DM 患 者14名及び正常人男女計73名の洗滌赤血球を用いた。 赤血球ソルビトールの測定は洗滌赤血球からソルビ トールを抽出し, ソルビトールがフルクトースに分解 される際に生じる NADH を蛍光比色法で定量し, $\mathrm{Hb}$ $1 g$ 当りのソルビトールの nmol 数で表わした.

結果：(1)「DM 患者の赤血球 (RBC) ソルビトール」 私共の手技による $\mathrm{RBC}$ ソルビトール測定の妥当性を 検定する目的で14名の DM 患者で測定した結果, 正常 者では平均値士標準誤差 $(\mathrm{M} \pm \mathrm{SEM})=8.25 \pm 0.602$ $\mathrm{nmol} / \mathrm{gHb}$ であるのに対し，DM患者では $\mathrm{M} \pm$ $\mathrm{SEM}=18.80 \pm 2.591 \mathrm{nmol} / \mathrm{gHb}$ と後者で有意の高值 を示した。（2）「実験的 STZ rat DM の RBCンルビ 


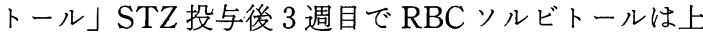
昇し，その值は $\mathrm{HbA}_{1}$, Plasma Glucose と正の相関を 示した.（3）「加齢と RBCソルビトール」男性22名, 女性51名の正常者で RBCソルビトールを測定したと ころ, $\mathrm{Y}=6.24+0.055 \mathrm{X}$ の回帰直線を示し, $\gamma=$ $0.285, \mathrm{p}<0.02$ で有意の正の相関を認めた．又この傾 向は男性の方に強い傾向があった。尚, $\mathrm{HbA}_{1}$ 及び空腹 時血糖と RBCソルビトールは有意の相関を示さな かった.

結論：以上より正常者に於ては, $\mathrm{HbA}_{1}$, 血糖値以外 の因子の関与で, RBCソルビトール濃度は加齢と共に 増加することを示した。

228. DNA 修腹阻害剤処理による末梢血リンパ球に みられる染色体異常における加齢性変化について（第 1 報)

$\begin{array}{llr}\text { 都老人総合研究所精神医学 } & \text { 本間 昭 } \\ \text { 杏林大成人保健 } & \text { 岸 邦和 }\end{array}$

末梢血リンパ球中に観察される染色体異常頻度の供 血者の年齢に伴う変化は, リンパ球中の DNA 損傷, DNA 修復能および DNA 合成系などの加龄による変 化の指標と考学ることが出来る。近年, 染色体異常の 生成期の DNA 損傷がシトシンアラビノシド（ara C) などの修復阻害剤処理により染色体型異常として検出 される可能性が示された。修復阻害剂による染色体型 誘発機構の詳細は不明であるが，加歯に伴う損傷など の変化に関する情報を提供するか否かを検討するため に, 末梢血リンパ球は $\operatorname{ara} \mathrm{C}$ が誘発する染色体異常頻 度と供血者の年齢との関連を調べた。

0 ～89歳の男女 40 名の末梢血を培養開始から 18 時間 $10 \mu \mathrm{M}$ ara $\mathrm{C}$ 処理し, 洗浄後 BrdUrd を含を培養液中 でさらに $42 \sim 47$ 時間培養した。作成した染色体標本の 第 1 回目の分裂中期像について染色体型異常を観察し た. 細胞100個当たりの ring + dic の頻度と供血者の年 齢との間には推計学的に有意な負の相関が認められた （y=77.3-36.08logX； y : 細胞100個あたりの頻度, $\mathrm{X}$ : 供血者の年齢 $; \mathrm{r}=3.15, \mathrm{p}<0.001)$. 本結果は加龄 に伴う DNA 損傷あるいは修復能の何らかの変化を反 映すると考光られる，ara Cの誘発する染色体型異常 頻度に影響を与えるいくつかの因子について検討を加 えこの結果について考察する。

229. 加齢と心臓, 神経系疾患の数理化 都老人医療センター
松下 哲, 萩原 弘一, 塩田 隆弘 嶋田 裕之, 蔵本 築, 豊倉 康夫

我々は細胞非再生器官である心臓, 神経系をとりあ げ, その主要疾患は加齢との関係で特有のパターンが あることを述べてきた。

今回はこの特有のパターンを数理化して表すため, 信頼性理論の一つであるワイブル分布関数を応用して みた。ワイブル関数は, 分布密度 $\mathrm{f}(\mathrm{t})=\mathrm{mt}^{\mathrm{m}-1} \mathrm{e}^{-t \mathrm{~m}}$ で表 される. 形状母数 $\mathrm{m}$ は $\mathrm{m}<1, \mathrm{~m}=1, \mathrm{~m}>1$ で各々初期 故障型, 偶発故障型, 摩耗故障型を表し, $\mathrm{m}$ が大であ るほど安定した時期が長い。日本剖検輯報昭和 52 年か ら56年までの $16 万$ 例の剖検例を対象とした。ワイブル 関数で適切に表世るかぞうか, そしてその $\mathrm{m}$ 值はワイ ブル確率紙をたは Simplex 法による非線型最適化法 を用いた。

この手法を第 1 回から15回の日本人生命表に応用す ると， 20 歳以前は $\mathrm{m}=0.2,20$ 歳から 50 歳までは $\mathrm{m}=$ $2.6 \sim 3.6,50$ 歳以降は $\mathrm{m}=7.3 \sim 9.3$ となり, 寿命の伸 びが, 20 代以降の $\mathrm{m}$ 值の増加で表現されることを確か めた. 剖検輯報の全症例もこのような $\mathrm{m}$ 值をとる複合 ワイブル分布を示した．各疾患で $\mathrm{m}<1$ 群は先天性心 疾患，二分脊髄，小頭症などの奇形，形成不全が該当 した. 他の疾患は殆ど $\mathrm{m}>1$ であるが, $\mathrm{m}$ の值にかなり の差がみられた。慢性リウマチ性心疾患 (4.2), 重症 筋無力症 (3.1), 多発性硬化症 (3.7) などの炎症, 免 疫が関係する疾患は比較的低い $\mathrm{m}$ 值の摩耗型, 脳出血 (4.8), 脳動脈瘤 (5.4), 大動脈瘤 (6.1), 脳梗塞 (6.7), 脳塞栓症 (6.5), 筋萎縮性側索硬化症 (7.8), 心筫梗 塞（男7.4女8.9）など変性，動脈硬化性疾患は高めの $\mathrm{m}$ 值の摩耗型を示した。 心筋梗塞は女性の方が男性よ り高齢発症なのが $\mathrm{m}$ 值にもよく表われている.従って 老年期に多い变性性, 血管性疾患は大部分が高い $\mathrm{m}$ 值 の摩耗型を示していた。

以上のごとく，ワイブル分布は疾患の年齢分布を表 現するのに適し，その形状母数 $\mathrm{m}$ は疾患の成因を反映 したり, 治療の余地，ひいては限界を示唆する可能性 がある。

\section{0. 老化に関する研究（第 7 報）90歳以上高齢者の 検査成績から}

杏林大衛生

古見 耕一，上畑鉄之丞，阿部 真雄 松岡 敏夫, 星本 米芳, 小川 正時 竹前 健彦 


$\begin{array}{ll}\text { 立川共済病院内科 } & \text { 森 } \\ \text { 琉球大保健医学 } & \text { 赤松 隆 } \\ \text { 防衛医大精神科 } & \text { 一ノ渡尚道 }\end{array}$

人口の高齢化がす寸む中で “健やかに老いる”とい らことが叫ばれ，多くの地域で健康づくり運動が展開 されている，私どもが長年追跡調査をしている佐敷町 も健康にかかわる運動が盛んであるが，同町は健康老 人が多いことでも知られている。そこで，今回は同町 の90歳以上で通常の生活をしている高齢者の健診成績 をねたきり老人のそれらと比較検討し，健やかに老い るための諸条件を模索した。

検索対象は 90 歳以上老人 23 人（平均年齢， $91.7 \pm$ 2.3)，ねたきり老人 36 人 (平均年齢， $84.2 \pm 8.0$ ) であ る. 高血圧は 90 歳以上老人で 1 人，ねたきり老人で 3 人と少なかった。血液検查結果は, 全般的にねたきり 老人に比し，90歳以上老人は良好で，とくに総蛋白質 90 歳以上老人 $7.4 \pm 0.8 \mathrm{~g} / \mathrm{d} l$, ねたきり老人 $6.7 \pm 0.5 \mathrm{~g} /$ $\mathrm{d} l$, アルブミンはそれぞれ $4.2 \pm 1.0 \mathrm{~g} / \mathrm{d} l, 3.4 \pm 0.4 \mathrm{~g} /$ $\mathrm{d} l$ と $1 \%$ の危険率で有意に高值であった. 血清総コレ ステロールは, 90 歳以上老人 $176.6 \pm 44.6 \mathrm{mg} / \mathrm{d} l$, ねた きり老人 $180.8 \pm 42.6 \mathrm{mg} / \mathrm{d} l$ と両群間に差はなく, 高 からず低からずの良い状態であった。，電図異常は秝 たきりの女で高率であった，健常者群（年齢80 89,

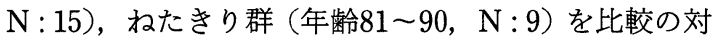
照とした血清遊離アミノ酸は，90歳以上老人 3 症例で あるが，全体として健常者群，ねたきり群，90歳以上 群の順に減少した。しかし，90歳以上群のグルタミン 酸, フェニールアラニンが健常者群のそれらに近い値 を示し，健康の維持との関連が示唆された。

健やかに老いるという目的に近づくには，生活環境 の面, 精神的側面, 身体的側面なぞ総合的に考党る必 要があるが，今回は身体的側面から検討した。先に示 した成績から，健やかに老いるには循環器系の管理が 重要で，それらに関連し加齢にともない食事中の蛋白 質にはとくに注意することが重要であるように考えら れた。

\section{1. 老化による癌転移様式の変化}

東京医歯大第二外科

坂本 眞, 平山 廉三，三島 好雄 都老人医療センター病理部江崎 行芳 都老人総合研基礎病理部広川 勝昱

目的：癌の担癌個体内での振舞い，とくに，転移様 式の年齢による变化について動物実験および胃癌剖検
例により検討した。

方法：動物実験；B16黑色腫 F10株（高頻度肺転移 株， Fidler 博士恵与) の $5 \times 10^{5}$ 個を 3 月齢， 22 月齢の 雌の C $57 \mathrm{BL} / 6 \mathrm{NNia}$ マウスの外耳皮下に接種し腫瘍 径が $4 \mathrm{~mm}$ に達した時点で耳介と共に初発癌巣の絶対 治癒的切断を行った。頝部リンパ節の増殖を経時的に 観察し, 適宜屠殺剖検して肺転移巣を病理組織学的に 検索した。胃癌剖検例；胃癌による癌死と考兄られ， かつ，原発巣の摘除されていなかった173例(20歳～97 歳）の剖検例について, 腹膜播種性転移, 肝転移抢よ びリンパ節転移につき組織型別（未分化型胃癌および 分化型胃癌）に老若二群間での転移の程度の比較を 行った.

結果：動物実験；a）初発癌巣の増殖には老若間に 差はなかったｂ）頝部リンパ節転移は老齢群で早期 に出現したが，その大きさは後に若齢群に追越された。 c）肺転移では老齢群で早期より不整形で invasiveな 転移巣が形成されたが小形のままにとどまるものが多 かった。一方，若齢群では遅れて球形で expansive な 転移巣が出現したが，まもなく，数，個々の転移巣の 大きさともに老齢群のそれを追い越した。胃癌剖検 例：a）腹膜播種性転移に関しては未分化型癌でも分 化型癌でも高㱓者群に転移の程度の軽いものが有意に 多かった，b）肝転移に関しては未分化型癌でも分化 型癌でも老若 2 群間に転移の程度に差は認められな かった，c）リンパ節転移に関しては未分化型癌では高 齢者群に有意に転移の程度の軽いものが多かったが, 分化型癌では老若 2 群間に転移の程度に差は認められ なかった。

\section{Werner 症候群における悪性腫瘍の合併}

東京女子医大リウマチ痛風センター 佐藤 和人, 宮坂 信之, 西岡久寿樹

東大物療内科後藤真

早期老化現象を示す Werner 症候群には, 悪性腫瘍, 特に間葉系由来の悪性腫瘍の多発が知られている。し かしながら，早期老化のメカニズム及び，悪性腫瘍発 生々の因果関係は現在まで不明の点が多い。

我々は本邦における1980年までに報告された悪性腫 瘍合併 の Werner 症候群を検討 し，195例中11例 （5.6\%）に悪性腫瘍の合伴のみられる事を既に報告し た (Clinical Genetics 19:8〜15，1981)。そこで，今 回，それ以降の悪性腫瘍を合併した Werner 症候群の 自験例 5 例，及び文献的に集積し得た本邦における 22 
例を比較検討した。自験例 5 例の内訳は, 甲状腺癌(腺 癌) 3 例, 膀脱癌 (移行上皮癌) 1 例, 横紋筋肉腫 1 例であり, 文献的に集積した症例は, 肺癌 2 例, 膀胱 癌 1 例, 肝癌及び胆管癌 2 例, 胃癌及び乳癌の重復癌 1 例, 口腔及び鼻腔の重複癌 1 例, 甲状腺癌 4 例, 悪 性線維性組織球症 3 例, 悪性黒色腫 3 例, 平滑筋肉腫 1 例，白血病 3 例，及び脳腫瘍 1 例であった。現在ま で, Werner 症候群における高頻度の悪性腫瘍の合併 が報告され，特に間葉系由来の腫瘍の多くみられる事 が指摘されているが，今回の我々の検討では，上皮性 細胞由来の癌, 特に, 甲状腺癌の合併を高頻度に認め た。今後，間葉系由来の腫瘍に加光て注目すべきと考 えられる。

Werner 症候群に打ける悪性腫瘍の合併について, そのメカニズムは明らかではないが，早期老化現象が その一因となっている事が示唆されている。我々はす でにWerner 症候群における免疫能の異常, 特にT細 胞及び NK 細胞の異常を報告しているが，これらの免 疫監視機構の異常も重要な役割を果たしていると考え られる。いずれにしても, Werner 症候群に拈ける早期 老化のメカニズムと悪性腫瘍合併の関連は, 今後検討 すべき問題を多数含んでいると考えられる。

\section{3. 耐糖能および年齢面よりの膵外分泌能に関する} 検討

日本医大老人科
武内 寛, 平井 真明, 中野 博司
山下 直博, 島田 研三, 野崎太矩祠
志賀 幸雄, 大庭 建三, 妻鳥 昌平
盤若 博司

目的：糖尿病の膵外分泌能に及ぼす影響に関する研 究は少なくないが，加齢の影響を考慮した成績は少な い. そこで而糖能および加齢の両者が脺外分泌能にお よぽす影響を検討した。

方法：対象は $75 \mathrm{~g}$ 経ロブドウ糖負荷試験を行なった 16歳から89歳までの154名で, インスリン依存性糖尿病 は除外した。耐糖能は糖尿病学会勧告值により正常型, 境界型掞よび糖尿病型に分類し，さらに糖尿病型につ いては空腹時血糖值 $140 \mathrm{mg} / \mathrm{d} l$ 未満を DM1, それ以外 をDM2群とし, 計 4 群に分類した. 年代別に若壮年群 (60歳未満) 抢よび老年群 (60歳以上) の 2 群に分類し た。膵外分泌能として，血清アミラーゼ (酵素法) と その分画, 血清ェラスターゼ 1 (RIA 法), 血清リパー ゼ（UV-rate 法）および血清トリプシン（RIA 法）を
早朝空腹時に測定した。

成績：耐糖能正常群での膵外分泌能々年齢の関係 は, 血清膵フミラーゼおよびトリプシンに有意の正の 相関を認めた，耐糖能別，年代別の膵外分泌能の検討 では, 1）若壮年群では, DM2群で血清膵アミラーゼ値 が正常型および境界型群に比し有意に低值であったの みで，他の指標には差はなかった。 2) 老年群では, (1) 血清膵アミラーゼ値は DM2 群が正常型群掞よび境界 型群に比し有意に低值であった。 (2)血清エラスターゼ 1 抢よびリパーゼ值は, DM2群が正常型群拈よび DM1群に比し有意に低値であった。 (3)血清トリプシン 值は, DM2群が正常型群に比し有意に低值であった。 またトリプシン值の年代別の検討では，DM1および DM2群には有意の差はなく, 正常型群でみられた加齢 の影響はなかった。

結論：耐糖能異常にともなら苾外分泌能の低下は年 代別に一様ではなかった。 DM1群は老若共に低下はな いが, DM2群では若壮年群が膵アミラーゼのみの低下 に対し, 老年群では全外分泌能に有意の低下を認めた。

\section{4. 膵線維化に関する組織化学的研究一細胞および 各種結合織の定量評価比}

東邦大臨床生理機能学

斉藤 光代, 安部 信行, 竹内 光吉

荒井 親雄, 長谷川元治

$\begin{array}{llrrr}\text { 同第一内科 } & \text { 泉水 } & \text { 昇, 内 } & \text { 孝 } \\ & \text { 森下 } & \text { 健, 白井 } & \text { 達男 } \\ \text { 同 } \mathrm{ME} & & & \text { 高山 } & \text { 吉隆 } \\ \text { 動脈硬化疫学研 } & & & & \end{array}$

中田 篤, 川下 治仁, 鈴木 賢二

目的：糖尿病の発症に直接関与している膵の結合織 代謝を Elastin(EL), Collagen(Ch), Glycosaminoglycans (GAGs), Glycoprotein (GP) 計 4 成分の組織 化学的観察, 定量から検討した.

対象・方法：対象は糖尿病，動脈硬化を認めない対 照群 29 例，糖尿病を有し，大動脈に占有面積率で $45 \%$ 以上のアテローム巣を有する糖尿病群 39 例の荤頭部小 葉間結合織とした。各結合織は特殊染色を施し, 顕微 分光測光法により吸光度量（\%Extinction, \%E) を測 定し定量した。

成績：組織を観察すると健常例では EL は小葉間に 一致し細長く染色されているが，線維としてはみられ ない. 糖尿病では増生を認めた。 CL は健常群で一条の 線維を小葉間に認めたが糖尿病では増生が著しく，基 
本的な小葉構造は破壊され，ラ氏島，腺旁細胞の障害 が㝝われた。 GAGs は健常例では細胞周囲の間質と小 葉間に少量みられた。糖尿病例ではそれらの部位での 増生がみられた，GP は健常例では細胞内にみられた が糖尿病例では間質での増生が明らかであった。各成

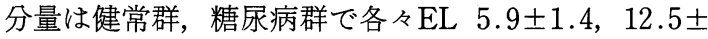
$2.2(\mathrm{p}<0.001), \mathrm{CL} 23.2 \pm 4.6,50.0 \pm 7.1(\mathrm{p}<0.001)$ ， GAGs $6.8 \pm 2.5, \quad 12.6 \pm 3.0(\mathrm{p}<0.001)$, GP $25.2 \pm$ $5.2 ， 34.1 \pm 8.7(\mathrm{p}<0.001)$ といずれの結合織成分も 糖尿病群で有意な増量を認めた。さらに 4 成分量を主 成分分析により総合評価し，両群の構築特性を対比し た. 第 I 主成分, 第II主成分での各因子負荷量は, 各々 EL $0.90,-0.16$, CL $0,94,-0.08$, GAGs 0.82 , -

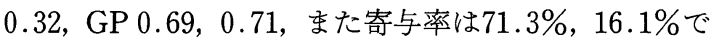
あった。 因子負荷量から各個体特点を求め， 2 次座標 上にプロットし分布領域を対比すると, 健常群は左方 の狭い領域，糖尿病群右方の広い領域とその分布に差 を認めた。

糖尿病傘では間質に括ける病的結合織の増生を示す ことは明らかだが, コラーゲン増量の組織学的様相は, ラ氏島細胞，腺旁細胞障害による 2 次的線維化とは考 えられない特性を持つものと推察された。

\section{5. 腎糸球体線維化に関する組織化学的研究一細胞 および各種結合織の定量評価}

$\begin{array}{cc}\text { 東邦大第一内科 } & \text { 泉水 昇, 内 孝 } \\ \text { 森下 } & \text { 健, 白井 達男 }\end{array}$

同 臨木生理機能学

安部 信行, 斉藤 光代, 竹内 光吉 荒井 親雄, 長谷川元治

同 $\mathrm{ME}$

高山 吉隆

動脈硬化疫学研

中田 篤, 川下 治仁, 鈴木 賢二 文部省統数研

駒澤 勉

目的：糖尿病に打ける Nephropathy は macroangiopathy とともにその予後を左右する上で重要 な合併症である。今回, 糖尿病に㧊ける腎 glomelus の 障害を組織化学的観察, 定量により検討した。

対象・方法：対象は糖尿病, 腎疾患を有さない健常 群38例 (平均年齢65.3歳), 糖尿病群41例(平均年齢67.6 歳)である。顕微分光測定法 (Microspectrophotometry, MSP) により, 腎 glomelurus の細胞, エラスチン, コラーゲン, Glycosaminoglycans
(GAGs)，糖蛋白計 5 成分を定量した。 1 症例につき平 均20個の glomelurus scanning method 主り吸光 度量（\%Extinction, \%E) を求めその平均を成分量と した。また，5成分量を主成分分析し，両群の構築特 性を多元的な視野より検討を加穴た。

成績：健常群，糖尿病群の各成分量は，各々細胞 $43.4 \pm 10.7,34.8 \pm 9.6 \% \mathrm{E}(\mathrm{p}<0.001)$, エラスチン $5.7 \pm 1.5,5.0 \pm 1.6 \% \mathrm{E}(\mathrm{NS})$, コラーゲン $18.0 \pm 2.9$, $29.6 \pm 4.6 \% \mathrm{E}(\mathrm{p}<0.001), \mathrm{GAGs} 9.6 \pm 2.2,7.4 \pm$ $2.1 \% \mathrm{E}(\mathrm{p}<0.001)$, 糖蛋白 $29.1 \pm 4.5,60.1 \pm 9.8 \% \mathrm{E}$ （p<0.001）であった。組織所見に执いても糖尿病群で はェラスチンのボーマンのうでの増生, 糸球体抢よび その周囲へのコラーゲンの増生, GAGs の不均一分布, 糖蛋白のボーマンのう, 系球体での増生が認められた。

主成分分析の結果, 第 1 主成分での因子負荷量は細 胞一 0.487，エラスチンー0.214，コラーゲン0.881, GAGs -0.578 , 糖蛋白 0.903 ，また第 2 主成分では各々 $0.100,-0.885,-0.273,-0.409,-0.151$ であった. た，第 1 ，第 2 主成分の寄与率は各々 $44.2 \% ， 21.2 \%$ であった。糖尿病の腎 glomelurus の細胞と結合織を 定量した結果, 細胞の障害, 減量, コラーゲン, 糖蛋 白の増生を認めた。これらの変化は網膜動脈，心筋内 細小動脈等全身にみられる microangiopathy の 1 病 型と考光られた。

\section{6. 赤血球グルタチオン還元酵素に関する研究一健 康人と糖尿病を中心に}

岡山赤十字病院内科

$$
\text { 中村 善一, 姫井 孟 }
$$

目的：.赤血球グルタチオン環元酵素（EGR）は， Glutathione peroxidase と共役する酵素であり，生体 内の過酸化物の制御抢よび赤血球膜の安定化に重要な 役割を担っているが，その臨床的意義に関しては不明 な点が多い，そこで今回，健常人と糖尿病患者を対象 に EGR 活性を測定し，他の臨床検査成績との関連を みた。

方法：対象は，健常者対象群として，ドックまたは 検診の目的で当科を受診し，特記すべき異常の認めら れなかった189名（女性95名，男性94名）之糖尿病患者 220名(女性123名，男性97名)。測定は，へパリン加採 血した赤血球を洗浄後, 氷冷蒸留水にて溶血し, 酸化 型グルタチオンを添加後, $\mathrm{NADPH}$ を加光, $37^{\circ} \mathrm{C} て ゙ 5$ 分間反応させ $340 \mathrm{~nm}$ に打ける吸光度の減少を測定し, 単位へモグロビンあたりの活性で表現した。さらに, 
反応系に補酵素である FAD を添加し, 赤血球中の全 $\mathrm{GR}$ 活性も同時に測定した。

結果：1）健常人対照群执よび糖尿病群の EGR 活 性は，それぞれ $5.00 \pm 1.07 \mathrm{U} / \mathrm{gHb}$ 㧊よび $5.00 \pm 1.02$ $\mathrm{U} / \mathrm{gHb}$ ，また $\mathrm{FAD}$ 添加後の $\mathrm{EGR}$ 活性は，それぞれ $6.25 \pm 0.92 \mathrm{U} / \mathrm{gHb}$ 㧊よび6.09 0.92U/gHbで，いず れも有意差はなく性差も認められなかった。 2) EGR 活性は, 両群とも60歳代までは加齢とともに有意に上 昇し，それ以降はゆるやかに低下寸る傾向が認められ たが, 糖尿病群では, より早期に EGR 活性が上昇する 傾向が認められた。 3）EGR 活性は, 末梢血赤血球数, 末梢血へモグロビン值, 血清コレステロール值, HDLコレステロール值怙よび HbAIC とは, 両群とも相関は 認められなかった。 また糖尿病の重症度および血管障 害の程度とも明らかな関連は認められなかった。

\section{7. 糖尿病治療のアポ蛋白に及ぼす影響}

朝日生命糖尿病研究所

$$
\begin{aligned}
& \text { 飯塚 孝, 福沢 尚子 } \\
& \text { 羽倉 稜子, 赤沼 安夫 }
\end{aligned}
$$

目的：糖尿病患者に和ける脂質代謝異常は治療によ り一定の改善をみるが，その実態と臨床的意義に関し ては不明の点が少なくない, 今回, 我々は糖尿病治療 が, 血清脂質, アポ蛋白, LCAT 活性にどのような影 響を及ぼすか検討した。

方法：対象は40歳以上101名の糖尿病患者(食事療法 単独群 27 名, 経口剂治療群 32 名, インスリン療法群 42 名）であり，入院時及び平均約 2 週間の入院加療後の 分析を行った. TG, T-CHOL は酵素法, HDL は塩沈 法, HDL 亜分画は超遠心法, アポ蛋白(A-I, A-II, B, C-II，C-III，E) は SRID 法, LCAT 活性は共通基質法 により測定した。

結果: 治療の効果に関して, 経口剂群は糖尿病状態 の改善と共に平均值で示すと $\left.\mathrm{TG}^{3}\right) 174 \rightarrow 105(\mathrm{mg} / \mathrm{d} l)$, T-CHOL ${ }^{1} 195 \rightarrow 172, \mathrm{HDL}^{2)} 45 \rightarrow 40, \mathrm{~A}-\mathrm{I}^{2)} 121 \rightarrow 113$, A- $-\mathrm{II}^{1)} 26 \rightarrow 24$, B $^{3)} 99 \rightarrow 90, \mathrm{C}-\mathrm{II}^{3)} 5.4 \rightarrow 4.3, \mathrm{C}-\mathrm{III}^{3)} 11.7$ $\rightarrow 8.4, \mathrm{E}^{2} 5.2 \rightarrow 4.2$, 体重は ${ }^{11} 55 \rightarrow 53(\mathrm{~kg}), \quad \mathrm{FBG}$ は $^{1)}$ $160 \rightarrow 103(\mathrm{mg} / \mathrm{d} l)$ といずれも有意に低下し, 食事療法 群も $\mathrm{FBG}^{1}$, 体重 ${ }^{1)}, \mathrm{T}-\mathrm{CHOL}^{3)}, \mathrm{C}-\mathrm{II}^{3)}, \mathrm{C}-\mathrm{III}^{1)}, \mathrm{E}^{1)}$ に 扔いて有意に低下した。インスリン群では体重 ${ }^{1} 56 \rightarrow$ $54(\mathrm{~kg}), \mathrm{FBG}^{2)} 162 \rightarrow 113(\mathrm{mg} / \mathrm{d} l), \mathrm{T}-\mathrm{CHOL}^{3)} 207$ $\rightarrow 194, \mathrm{HDL}^{3)} 53 \rightarrow 50(\mathrm{mg} / \mathrm{d} l)$ と改善したものの A-II ${ }^{1)}$ $25 \rightarrow 22(\mathrm{mg} / \mathrm{d} l)$ と低下したが他のアポ蛋白に有意差は なく, A-I/A-II 比は2)5.0 5 5.7 と有意に上昇した。
HDL2-Cは有意な変動はなく, HDL3-C は ${ }^{1)} 30.5 \rightarrow$ $23.1(\mathrm{mg} / \mathrm{d} l)$ と有意に低下し, HDL2-C/HDL3-C 比 は1) $0.91 \rightarrow 1.30$ と有意に上昇した（1) $\mathrm{p}<0.001$, (2) $\mathrm{p}<0.01$, (3) $\mathrm{p}<0.05$ ).

結論：40歳以上の糖尿病患者 101 名について検討し, (1) T-CHOLはインスリン, 経口剂, 食事療法各群に打 いて減少した。 (2) TG が顕著に低下した経口剂群では アポ B, C-II, C-III, E の低下をみた. (3) HDL-C イン スリン, 経口剤治療により減少した。 (4)インスリン治 療群に抢いて, A-II, HDL-C の減少をみとめ A-I/A-II 比, HDL2-C/HDL3-C 比は増加した. 以上ょり, イン スリン治療は HDL の構成粒子に変化をもたらす可能 性が示された。

\section{8. 老年者糖尿病の間歇性蛋白尿に関する検討一主 としてNAGょクの検討}

日本医大老人科

平井 真明, 野中 良化, 魚住 敏 中野 博司, 㴊上 正章, 野崎太矩祠 志賀 幸雄, 大庭 建三, 妻鳥 昌平 盤若 博司

目的：糖尿病患者の間歇性蛋白尿は, 糖尿病性腎症 の指標とされているが，老年者では非糖尿病患者にお いても間歇性蛋白尿を認める頻度は少なくない。そこ で老年者糖尿病患者の間歇性蛋白尿の臨床的意義を主 として糖尿病性腎症の診断の指標とされている NAG の面より検討した。

方法：対象は，当科外来を定期的に受診中の糖尿病 患者144名拉よび非糖尿病老年患者で間歇性蛋白尿を 有する39名である，対象を，若壮年群(60歳未満)，老 年群の 2 群に, 糖尿病患者は尿蛋白陰性, 間歇性蛋白 尿拉よび持続性蛋白尿群に分け, 更に間歇性蛋白尿群 は糖尿病性網膜症の有無により 2 群に分け, 計 5 群と した．全例に，血清 BUN, クレアチニン, $\beta_{2} \mathrm{MG}$ ，尿 中 NAG-index, $\beta_{2} \mathrm{MG}$ を測定した.

結果：1）血清 BUN, クレアチニン, 血清抒よび尿 中 $\beta_{2} \mathrm{MG}$ は各糖尿病群および, 非糖尿病間歇性蛋白尿 群の 5 群間にいずれも有意の差はなかった。2) 尿中 NAG-index は, (1)若壮年群では, 健常者群 (C 群) に 比し, 糖尿病のすべての群で有意に高值であり, 尿蛋 白陰性, 間歇性蛋白尿, 持続性蛋白尿群の順に高值で あった。(2)老年群においても同様に糖尿病の各群はC 群に比し有意に高值であったが, 尿蛋白陰性群と網膜 症（一) 間歇性蛋白尿群の間には有意の差はなかった。 
前 2 者に比し網膜症 (十) 間歇性蛋白尿および持続性 蛋白尿群は有意に高值であった。 (3)老年者の非糖尿病 間歇性蛋白尿群は $\mathrm{C}$ 群に比し有意に高值であり, 糖尿 病尿蛋白陰性抒よび網膜症（一）間歇性蛋白尿群との 間に有意の差はなかった。 (4)非糖尿病性間歇性蛋白尿 群の臨床像を検討するとその大部分に高血圧症の合併 を認めた。

結論：老年糖尿病者の間歇性蛋白尿群は非糖尿病者 のそれに比べ各種腎機能および尿中 NAGも差がな く, 老年糖尿病性腎症の早期指標としての間歇性蛋白 尿の意義は若壮年者に比べて少なく，他の動脈硬化性 疾患にもとづく間歇性蛋白尿との鑑別も困難なことが 多い。

\section{9. 老年者高血圧合併糖尿病における尿中 NAG 測 定の臨床的意義}
日本医大臨床病理科
冨山元次郎

$\mathrm{N}$-acetyl- $\beta$-D-glucosaminidase (NAG) は近位腎尿 細管上皮細胞由来の Lysosome 酵素のひとつであっ て，同酵素の尿中排泄増加は腎尿細管障害の鋭敏な マーカーとして有用性が認められている。それゆえ老 年者糖尿病患者について高血圧症を合併した際の病態 を検討し，さらに高血圧，糖尿病の治療経過に伴う尿 中 NAG 活性の推移を検討した。

方法：対象は老年者高血圧合併糖尿病60例，正常血 圧の老年者糖尿病60例である。検査項目は血糖，尿糖， $\mathrm{HbA}_{1}, \mathrm{HbA}_{1} \mathrm{c}$ ，尿タンパク，血中，尿中 $\beta_{2}$ マイク口 グロブリンであって，尿中 NAG 測定は NAG テスト （シオノギ）を用い， NAG 指数〔尿クレアチニン $(\mathrm{g} /$ $l$ ) 当りの NAG 活性 $(\mathrm{U} / l)$ ] で表示した。高血圧の分 類は軽症，中等症，重症の 3 群に分け，高血圧治療に は主としてアンジオテンシン変換酵素阻害剤 Captopril を使用した。

成績 : 老年者高血圧合併糖尿病群の尿中 NAG 指数 は11.5 $\pm 6.3 \mathrm{U} / \mathrm{g} ・$ creat $(\mathrm{M} \pm 1 \mathrm{SD})$ であって，高血圧 の軽症, 中等度, 重症の順に高値を示した。一方正常 血圧の老年者糖尿病群では NAG 指数は $4.7 \pm 3.2 \mathrm{U} /$ $\mathrm{g}$ •creat であって, 健常老年者対照群よりは高いが, 高 血圧合併老年糖尿病群に比べ有意 $(\mathrm{p}<0.01)$ に低值で あった，尿タンパク陰性の老年者糖尿病を高血圧の有 無によって比べると，高血圧合併老年者群において NAG 指数は高值を示した。高血圧合併老年者糖尿病 群において, Captopril 単独治療により降圧効果のみ られた者では尿中 NAG 指数は著明に低下した。
結論：1）高血圧を合併した老年者糖尿病では糖尿 病の夕の群に比べ尿中 NAG 活性および指数は高值を 示した. 2）高血圧の治療効果による NAG 指数の変動 は収縮期血圧の変動とよい相関を示した．3）尿中 NAG は血圧の変動, 血糖コントロールの良否に対応 し，比較的短期間に变動した。 4）老年者の糖尿病抢よ び高血圧の管理に際し，尿中 NAG の検査は有意義で ある。

\section{0. 糖尿病患者における尿中 NAG一多変量解析に よる検討}

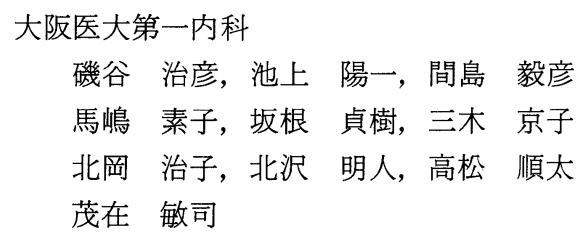

目的：糖尿病患者における尿中 NAG の増加につい て腎障害, 血糖コントロール状態などとの関係が示さ れているが，その臨床的意義は十分明らかにされてい ない，我々は糖尿病患者の尿中 NAG の増加が主にど のような因子に関連しているかを，多変量解析を用い て検討した。

方法：対象は健常者35例（24 88, 平均 $56 \pm 19$ 歳), 糖尿病患者 109 例 (17 82, 平均 $58 \pm 13$ 歳) である，尿 中 NAGは早朝空腹時尿を用いMCP-NAGテスト （シオノギ）で測定し尿中クレアチニン值で補正した。 健常者扣よび糖尿病患者を年齢別に分け加齢による影 響を検討した． 糖尿病患者はさらに高血圧の有無によ り分けその影響を検討した。尿中 NAG と関連がある と考光られる臨床所見のうち年齢, 罹病期間, $\mathrm{HbA}_{1} \mathrm{c}$, FPG，蛋白尿，BUN，s-creatinine，s- $\beta_{2} \mathrm{MG}$ ，糖尿病 性網膜症の 9 項目について相互の影響を排除したとき の尿中 NAG への影響を検討するため多变量解析を行 ないNAGを予測する立場で重回帰分析による変数選 択を行なった。

結果：1）糖尿病患者の尿中 NAG は平均 $8.9 \pm 5.6$ $\mathrm{U} / \mathrm{g} \cdot$ creat で健常者の $3.1 \pm 1.7 \mathrm{U} / \mathrm{g} \cdot$ creat に比べ有意 （p<0.001）に高值を示した．2）尿中 NAG は健常者 では29歳以上；平均 $2.0 \pm 0.3,30 \sim 49$ 歳； $2.3 \pm 1.0$, $50 \sim 69$ 歳 ; $3.5 \pm 2.0,70$ 歳以上 $; 5.1 \pm 1.5 \mathrm{U} / \mathrm{g} \cdot \mathrm{creat}$ と加齢に従い有意に増加した。一方糖尿病患者ではそ

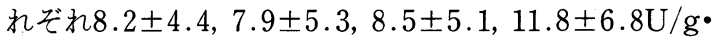
creat で70歳以上の群では他の群より高値を示した。 3）糖尿病患者の尿中 NAGは血圧との間に明らかな 
関係は認めなかった.4）臨床所見10項目の単相関分析 の結果, 糖尿病患者の尿中 $\mathrm{NAG}$ は $\mathrm{HbA}_{1} \mathrm{c}, \mathrm{FPG}$, 蛋 白尿招よび $\mathrm{s}-\beta_{2} \mathrm{MG}$ と高い相関を示した。これに年齢 を加えた 5 項目について偏相関分析を行なった結果, 尿中 $\mathrm{NAG}$ は $\mathrm{HbA}_{1} \mathrm{c}$, 蛋白尿および年齡の 3 因子と相 関 $(r=0.506, r=0.303, r=0.292$, 寄与率 $55.9 \%)$ 乙 た。すなわち尿中 $\mathrm{NAG}$ は加齢のほか $\mathrm{HbA}_{1} \mathrm{c}$, 蛋白尿 の程度を反映して変動することが示された。

241. 健常者および糖尿病患者における末梢リンパ球 のIL-2産生能に関する検討

$$
\text { 聖マリアンナ医大第三内科 }
$$

$\begin{array}{lrrrr}\text { 太田 } & \text { 康晴, 岡野 } & \text { 一年, 野沢 } & \text { 保興 } \\ \text { 清水 } & \text { 真, 根岸 } & \text { 代, 西川 } & \text { 真人 } \\ \text { 渡辺 } & \text { 高典, 石川 } & \text { 雅, 木村 } & \text { 聡 } \\ \text { 星 } & \text { 賢二, 佐野 } & \text { 隆志, 染谷 } & \text { 一彦 }\end{array}$

目的: Interleukin 2 (IL-2) は，免疫応答系におい

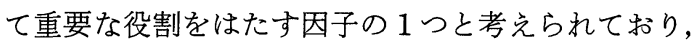
加齢により異常を示すことが報告されている，今回わ れわれは，ヒト末梢血リンパ球の IL-2産生能を加齢お よびヒト糖尿病患者に打いて検討したので報告する。

方法：対象は健常者 22 名 (平均42.5歳), インスリン 依存型糖尿病 (IDDM) 9名 (平均 25.3 歳), インスリ ン非依存型糖尿病 (NIDDM) 13名 (平均52.6歳) であ る. 末梢血単核細胞を Ficoll-Conray 比重遠心法に上 り分離後， $2 \times 10^{6}$ 個を $1 \mathrm{~m} l 5 \% \mathrm{FCS}, \mathrm{RPMI} 1640$ 亿浮 遊させ, Con A $10 \mu \mathrm{g}$ とともに $5 \% \mathrm{CO}_{2}$ 下 $37^{\circ} \mathrm{C} 24$ 時間培 養した。その培養上清または標準 IL-2溶液 $100 \mu 1$ を $5 \% \mathrm{FCS}$ ・RPMI $1640100 \mu l$ に浮遊させたマウス IL2依存性細胞 (CTLL-2) $8 \times 10^{3}$ 個とともに $5 \% \mathrm{CO}_{2}$ 下 $37^{\circ} \mathrm{C} 20$ 時間培養後, $20 \mu l 5 \% \mathrm{FCS} \cdot \mathrm{RPMI} 1640$ に溶解 した $0.5 \mu \mathrm{Ci}\left[{ }^{3} \mathrm{H}\right]$-thymidine を加へ，さらに 4 時間培 養し, 細胞内への $\left[{ }^{3} \mathrm{H}\right]$-thymidine の取り込及量から IL-2活性を算出した。

成績：健常者群の IL-2活性は $0.25 \pm 0.14 \mathrm{U}$ （平均士 標準偏差) であり，年齢との間に有意の相関をみとめ なかった. IDDM群の IL-2活性は0.24 $00.12 \mathrm{U}$, NIDDM 群では $0.43 \pm 0.27 \mathrm{U}$ であり, IDDM 群では年 齢を合わせた健常対照群に比して有意の変動をみとめ なかった. NIDDM 群でも年齢を合わせた健常対照群 およびIDDM 群に比して有意の変動をみとめなかっ た。また IDDM 群の IL-2産生能は $\mathrm{HbA}_{1}$ との間に有意 の正相関をみとめた $(\mathrm{p}<0.05)$. NIDDM 群の IL-2産 生能は, $\mathrm{HbA}_{1}$ 值と有意の相関をみとめなかった。
IDDM 群, NIDDM 群は罹病期間との間に有意の相関 をみとめなかった。

結論：加齢や糖尿病に打ける免疫異常に関してはい まだその詳細は不明である。末梢血りンパ球の IL-2産 生能は, 加齢により有意に変動せず, IDDM群や NIDDM 群でも対照群に比して有意に変動しなかった が，IDDM 群で $\mathrm{HbA}_{1}$ との間に有意の正相関をみとめ たことから, IDDM に和ける免疫異常の存在が示唆さ れる。

\section{2. 糖尿病患者の培養末梢血リンパ球表面マーカー の two-color flowcytometry 法による検討 聖マリアンナ医大第三内科}

$\begin{array}{lrrrr}\text { 野澤 } & \text { 保興, 岡野 } & \text { 一年, 太田 } & \text { 康晴 } \\ \text { 清水 } & \text { 真, 渡辺 } & \text { 高典, 根岸 } & \text { 代 } \\ \text { 西川 } & \text { 真人, 星 } & \text { 賢二, 佐野 } & \text { 隆志 } \\ \text { 染谷 一彦 } & & & & \end{array}$

目的：糖尿病，とくにインスリン依存型糖尿病 (IDDM) は, その発症に免疫学的異常の関与が示唆さ れる. 今回, われわれは, 健常者や糖尿病患者の末梢 血単核細胞を Con A と in vitroで培養し, helper/inducer T cell や suppressor/cytotoxic T cell における interleukin 2 receptor (IL2R) p transferrin receptor （TFR）を two-color flowcytometry 法により検討し たので報告する。

方法: 対象は, 健常者16例, IDDM 7 例 (平均年齢 25.8 歳)，インスリン非依存型糖尿病 (NIDDM) 10例 （平均年齢55.1歳）である. 末梢血単核細胞を FicollHypaque により分離後, $10 \mu \mathrm{g} / \mathrm{ml}$ Con A を含む $5 \%$ $\mathrm{FCS} \cdot \mathrm{RPMI} 1640$ 中で $5 \% \mathrm{CO}_{2}$ 下 $37^{\circ} \mathrm{C}$ で 3 回間培養し た。これに phycoerythrin 拈よび FITC 標識モノク ローナル抗体 IL2R, TFR, Leu $3 \mathrm{a}+3 \mathrm{~b}$ (helper/inducer $\mathrm{T}$ cell), Leu 2a (suppressor/cytotoxic $\mathrm{T}$ cell) を加光, IL2R ${ }^{+}$細胞, $T F R^{+}$細胞, IL2R ${ }^{+}$Leu $3 a+3 b^{+}$ 細胞, IL2 $\mathrm{R}^{+}$Leu $2 \mathrm{a}^{+}$細胞, $\mathrm{TFR}^{+}$Leu $3 \mathrm{a}+3 \mathrm{~b}^{+}$細胞, $\mathrm{TFR}^{+}$Leu $2 \mathrm{a}^{+}$細胞の百分率をフローセルンーター （日本分光社製，FCS-1型）をもちい, two-color flowcytometry 法により測定した。

結果 : 健常者に扮いて, IL2R+細胞, TFR ${ }^{+}$細胞, IL2 $\mathrm{R}^{+}$Leu $3 \mathrm{a}+3 \mathrm{~b}^{+}$細胞, IL2 $\mathrm{R}^{+}$Leu2 $\mathrm{a}^{+}$細胞, $\mathrm{TFR}^{+}$Leu $3 a+3 b^{+}$細胞, TFR ${ }^{+}$Leu $2 a^{+}$細胞拉よび Leu $3 a+3 b^{+}$ Leu $2 \mathrm{a}^{+}$細胞はそれぞれ加齢により有意に低下した $(\mathrm{p}<0.01)$. IDDM では, IL $2 \mathrm{R}^{+}$Leu $3 \mathrm{a}+3 \mathrm{~b}^{+}$細胞p $\mathrm{TFR}^{+}$Leu $3 \mathrm{a}+3 \mathrm{~b}^{+}$細胞は年齢をあわせた健常時に比 
して有意に低下した $(\mathrm{p}<0.05)$. NIDDM では, IL2R+ Leu $2 \mathrm{a}^{+}$細胞や $\mathrm{TFR}^{+}$Leu $2 \mathrm{a}^{+}$細胞は年齢をあわせた 健常群に比して有意に増加した $(\mathrm{p}<0.02)$. IDDM で は NIDDM インスリン治療群に比して, IL2R+細胞や IL2 $\mathrm{R}^{+}$Leu $3 \mathrm{a}+3 \mathrm{~b}^{+}$細胞は有意に低下した $(\mathrm{p}<0.05)$. NIDDM インスリン治療群は NIDDM 食事療法群十 $\mathrm{SU}$ 剂治療群に比して, IL2 $\mathrm{R}^{+}$Leu $3 \mathrm{a}+3 \mathrm{~b}^{+}$細胞は有意 に増加した $(\mathrm{p}<0.05)$.

\section{3. 老年者糖尿病例の免疫能一特に慢性尿路感染症} について

都老人医療センター

白木 正孝, 大山 俊郎, 中野 忠澄 森 聖二郎, 藤巻 博, 佐藤 忠弘

井藤 英喜, 菊地 哲也 東大老年病科 折茂 肇

はじめに：老年者糖尿病に扣いて尿路感染症の合併 はしばしばみられ, 慢性の経過をたどる場合, 腎不全 を招来し，その予後を不良とする。従来より，糖尿病 の免疫機能については，低下するとの報告もあるが， 老年者糖尿病で慢性尿路感染症を有するものの免疫能 については報告がない，そこで我々は，これらの症例 について, リンパ球表面マーカーの分布を検討したの で報告する。

対象：対象は全例 50 歳以上の老年者である。老年者 を正常群（糖尿病及び尿路感染症を有さない例；C 群, $\mathrm{n}=40$ ), 糖尿病群（糖尿病は有するが，尿路感染症を 有さない群; DM, n=15), 及び糖尿病感染症群(糖尿 病を有し, 慢性尿路感染症を有する群；DMI, $\mathrm{n}=10$ ) の 3 群に分類した。ここで DMI 群の定義は，6 カ月以 上にわたり, 細菌尿, 膿尿を有するが, CRP は陰性, 白血球増多，発熱等炎症所見を有さない尿路感染症を 有する糖尿病例とした。リンパ球表面マーカーとして は Leu 2a，3a，4，7，11a，HLA-DR 及び OKMI を 用い同時に $N K / K$ 細胞活性も測定した。

結果：C 群に打ける Leu 4, 3a，2a，HLA-DR の陽 性率は，それぞれ $64.0 \pm 1.9 ， 41.0 \pm 1.6 ， 26.0 \pm 1.7$ ， $23.0 \pm 0.9 \% \mathrm{DM}$ 群のそれは，それぞれ $66.0 \pm 2.2$,

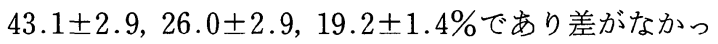

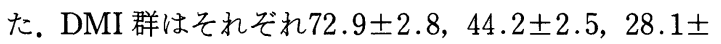
$3.1 ， 22.2 \pm 1.8 \%$ であり DMI 群で C 群に比し Leu 4 陽性率が高かった。一方 Leu 7, 11a, OKMI 及び NK/ $\mathrm{K}$ 活性は C 群 $28.0 \pm 1.6 ， 22.0 \pm 1.9 ， 39.0 \pm 1.6$ 及び $28.0 \pm 1.7 \%$ に比し, DM 群 $22.0 \pm 2.2,20.0 \pm 2.0$,
$32.0 \pm 2.2$ 及び $33.7 \pm 4.1 \%$ C C DM 群間では Leu 7のみが有意の低值を示した。一方 DMI 群はそれぞ

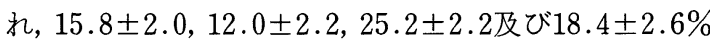
であり,これは DM 群に比し全て有意の低值を示して いた。

結論：慢性尿路感染症を有する老年者糖尿病例で は, inducer/helper 又は Supressor/cytotoxic T cell 機能よりも, $\mathrm{NK} / \mathrm{K}$ 細胞活性が低下していることが示 唆された。

\section{4. 老年者糖尿病におけるグルカゴン試験の評価} 旭川医大第三内科

夈井 康孝, 高杉 佑一, 並木 正義 市立旭川病院内科

武藤 英二, 武田 章三

目的：最近糖尿病患者に括ける残存膵 $\mathrm{B}$ 細胞機能 検査としてグルカゴン静注時の血清 C-peptide（以下 CPR) 反応 (以下グルカゴン試験) が注目されている. この反応が良好なものはインスリン治療中であって も，インスリンから離脱できる可能性が高いといわれ ている。しかし老年者についても同様のことがいえる かぞうか検討した報告は少ない，そこで今回我々は老 年者糖尿病を中心にグルカゴン試験の有用性について 検討したので報告した。

方法：NIDDM 60 歳以上を老年群 $(\mathrm{n}=32), 60$ 歳 未満を非老年群 $(\mathrm{n}=48)$ とし，インスリン治療者のう ち食事療法や経口血糖降下剂に治療法を変更できたも のをインスリン離脱群，できなかったものをインスリ ン継続群として検討した。グルカゴン試験は, グルカ ゴン $1 \mathrm{mg}$ を静注し，その前拉よび 6 分後の CPRを RIA 法を用い測定し，その差を $\triangle \mathrm{CPR}$ とした。

結果：非老年群では食事療法群の $\triangle \mathrm{CPR}$ が1.85土 $0.23(\mathrm{ng} / \mathrm{m} l, \mathrm{M} \pm \mathrm{SE})$ であるのに対し, インスリン 治療群では $0.60 \pm 0.11$ と有意 $(\mathrm{p}<0.01)$ に低かった。 一方老年群ではインスリン治療群でも $1.73 \pm 0.45$ と非 老年食事療法群に近い值であった。非老年群に执いて は離脱群の CPR 6 分值, $\triangle \mathrm{CPR}$ はそれぞれ $2.06 \pm$ $0.38 ， 1.23 \pm 0.23$ で継続群の $1.13 \pm 0.24,0.37 \pm 0.09$ に対し有意 $(\mathrm{p}<0.05, \mathrm{p}<0.01)$ に高かった。一方老 年群に抢いては離脱群の $\mathrm{CPR} 6$ 分值， $\triangle \mathrm{CPR}$ はそれ

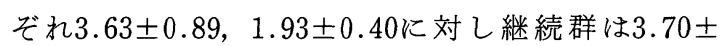
1.10,1.57士0.56であり両者に有意差を認めなかった。 離脱群のインスリン離脱後の再検査では老年群の $\triangle \mathrm{CPR}$ は $1.20 \pm 0.39$, 非老年群のそれは $1.49 \pm 0.27$ と 
有意の変化を示さなかった。 なた離脱前後で尿 $\mathrm{CPR}$ 排泄に一定の増加の傾向は認めなかった。

結語：老年者では, CPR 反応が必ずしも治療法に反 映して抢らず, CPR 6 分值, $\triangle \mathrm{CPR}$ が高くともインス リン治療を必要とするものが多い点は注意を要すると 思われた。

\section{5. 老年者 Sucrose 経ロ負荷と Sucrosuria} 金沢医大老年病科

$\begin{array}{lrrr}\text { 関本 博, 堀部 尚久, 松本 } \text { 正幸 } \\ \text { 中野 利美, 鈴木 俊之, 森本 悦司 } \\ \text { 林 光義, 石川 紀子, 土屋 } & \text { 博 } \\ \text { 生垣 博行 } & & & \end{array}$

目的：従来帛とんど報告されたことのない定量的 Sucrosuria の動態について検討を加党老年糖尿病患 者 (平均72.8土6.0歳) を対象にSucroseを経口投与し て, Sucrosuria の病態生化学的考察を加光, その意義 解明を目的に本研究を行った。

方法：老年糖尿病患者 65 歳から 83 歳までの平均 72.8 歳の10例に Sucrose を経口負荷して, 負荷前, 30分, 60分，120分の各尿をわれわれの方法で Sucrosuria の 定量分析を行ない正常健常者と比較検討した。なお, 腎機能と肝機能に障害のない糖尿病患者を対象とし た。

結果：(1)糖尿病者群の尿中 Sucrose 量は, 各時間, $1.42 \pm 0.95 \mathrm{mg} / \mathrm{d} l, 37.40 \pm 16.06 \mathrm{mg} / \mathrm{d} l, 131.60 \pm 1.16$ $\mathrm{mg} / \mathrm{d} l, 168.25 \pm 37.12 \mathrm{mg} / \mathrm{d} l$ で, 正常者群は, $3.40 \pm$ $1.16 \mathrm{mg} / \mathrm{d} l, 9.50 \pm 2.60 \mathrm{mg} / \mathrm{d} l, 9.72 \pm 1.57 \mathrm{mg} / \mathrm{d} l$, $5.09 \pm 0.89 \mathrm{mg} / \mathrm{d} l$ で, 30 分值, 60 分值, 120 分值が老年 糖尿病者群で有意に高值であった。（2)尿中 Fractose 量は糖尿病者群, $5.83 \pm 1.62 \mathrm{mg} / \mathrm{d} l, 45.46 \pm 18.93 \mathrm{mg} /$ $\mathrm{d} l, 101.28 \pm 27.18 \mathrm{mg} / \mathrm{d} l, 129.41 \pm 36.79 \mathrm{mg} / \mathrm{d} l$, 正 常者群で, $6.10 \pm 1.24 \mathrm{mg} / \mathrm{d} l, 20.00 \pm 4.25 \mathrm{mg} / \mathrm{d} l$, $29.21 \pm 5.84 \mathrm{mg} / \mathrm{d} l, 5.40 \pm 1.08 \mathrm{mg} / \mathrm{d} l$ でやはり 30 分 値, 60 分值, 120 分值が老年糖尿病者群で有意に高值で あった. (3)尿中 Glucose 量は, 糖尿病者群で, $79.25 \pm$ $48.70 \mathrm{mg} / \mathrm{d} l, 248.48 \pm 106.61 \mathrm{mg} / \mathrm{d} l, 562.03 \pm 209.12$ $\mathrm{mg} / \mathrm{d} l, 797.11 \pm 247.85 \mathrm{mg} / \mathrm{d} l$, 正常者群では, $5.96 \pm$ $2.32 \mathrm{mg} / \mathrm{d} l, 6.19 \pm 2.17 \mathrm{mg} / \mathrm{d} l, 15.87 \pm 6.30 \mathrm{mg} / \mathrm{d} l$, $2.05 \pm 0.55 \mathrm{mg} / \mathrm{d} l$ で, 負荷前後すべて老年糖尿病者群 が有意に高值を示した。 (4)糖尿病者群で合併症につい て比較検討したが, 網膜症 (Scott IIa から IIIb) につ いては，尿中 Sucrose 量の高值に有意の結果がえられ
た. 神経症の有無, 冠不全の有無も比較検討したが, 各時間すべて有意差は認められなかった. (5) $\mathrm{HbA}_{\mathrm{r}}$ を 7.5\%を境に比較検討したが，30分値，60分値の Sucrosuria に有意差が認められた。

以上のごとく Sucrose の吸収排泄と糖尿病合併症, 特に血管合併症に強いかかわりをもつことを示唆する 成績がえられたので報告する。

\section{6. 糖尿病患者のレニン・アルドステロン系と体液} 量一インスリン投与前後における検討

群馬大第二内科 中村 哲也, 市川 秀一
八木 温子, 村田 和彦

目的：糖尿病患者のレニン・アルドステロン系（RA 系）は正常と異なることが報告されているが，インス リン(Ins)治療による RA 系の変化を検討した. Insに は $\mathrm{Na}$ 貯留作用があるとされているので，体液量を Ins 投与前後で測定し，RA 系との関係を検討した。

方法：未治療の糖疗病患者 7 名を，入院，減塩 $5 \mathrm{~g}$, 体重あたり20～30kcal の食事下に，10日目より検討を 開始した。 1 日尿糖を連日測定し，コントロール期間 ののち, 朝食前に, Ins $8 \sim 24$ 単位の皮下投与を行っ た. Ins 投与 14 日目まで，3日〜 4 日間隔で空腹時血糖 (FBS), 赤血球容積 $(\mathrm{Ht})$, 血清 $\mathrm{Na}, \mathrm{K}, 24$ 時間 $\mathrm{Ccr}$, 血浆レニン活性（PRA），血浆アルドステロン濃度 （PAC）を測定した。 また Ins 投与前と投与後14日目 に, 循環血浆量 (PV) と細胞外液量 ( $\mathrm{ECF}$ )を, エバ ンスブルーとチオシアン酸ソーダを用いた指示薬稀釈 法により，それぞれ測定した。

結果：FBSはIns 投与前 $194 \pm 17 \mathrm{mg} / \mathrm{d} l$ (mean土 $\mathrm{SE})$ より投与後 14 日目には， $144 \pm 16$ と有意 $(\mathrm{p}<0.05)$ に低下し，尿糖も有意 $(\mathrm{p}<0.05)$ に減少した。 血清 $\mathrm{Na}$, K，24時間 Ccr に変化はみられなかった. Ht は Ins 投 与前 $41 \pm 2$ から投与後 14 日目には $38 \pm 2$ と有意 $(\mathrm{p}<$ 0.05）に減少した. PV は前值 $40.3 \pm 2.8 \mathrm{ml} / \mathrm{kg}$ から,

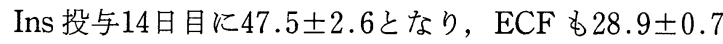
$l / \mathrm{kg} \times 100$ から 14 日目に, $30.4 \pm 1.1$ といずれも有意 $(\mathrm{p}<0.05)$ に増加した。 PRA は Ins 投与前 $3.8 \pm 1.4$ $\mathrm{ng} / \mathrm{ml} / \mathrm{hr}$ から 14 日目には $1.2 \pm 0.3$ と有意 $(\mathrm{p}<0.05)$ に抑制された。 PACは $112 \pm 15 \mathrm{pg} / \mathrm{m} l$ から14日目に $99 \pm 12$ と減少したが有意ではなかった。

考案：今回の症例は減塩食 $5 \mathrm{~g}$ 下に拈ける検討であ るが， RA 系の基礎値は正常範囲内にあった. Ins 投与 により RA 系, 特に PRA は抑制されたが, これは体液 量の増加によるものと考えられる。 またこの体液量の 
増加は, 尿糖による浸透圧利尿の消失と Ins の腎での $\mathrm{Na}$ 貯留作用によると推察される。

247. 老年者糖尿病の血糖值コントロール指標として の朝食前および朝食後血糖の臨床的意義一HbA1より の検討

日本医大老人科

大庭 建三, 春山 勝, 南 順文 中野博司, 山下 直博, 㴊上正章 高尾 嘉興, 野崎太矩祠, 志賀 幸雄 妻鳥 昌平, 盤若 博司

目的：老年者糖尿病患者の血糖コントロールの指標 としての朝食前 (FPG) 和よび朝食後血糖值 (PPG) の臨床的意義を $\mathrm{HbA1}$ 值の面より検討した.

方法：対象は当科外来を定期的に受診し，血糖値拉 よび HbA1值を測定した17歳〜87歳までのインスリン 非依存性糖尿病患者223名である。血糖測定時の年齢に より若壮年群 (60歳未満) と老年群の 2 群に分類. 交 た, 治療法別に食事療法群扔よび薬物療法群の 2 群に 分類した. PPG は朝食後 $2 \sim 3$ 時間の間に測定. 総検 体数は FPG 2,176検体, PPG 1,251検体である. HbA1 はミニカラム法にて測定, 一部は不安定分画を除去し, HPLC 法にて HbA1c 值を測定した。血糖は, 静脈血 浆，オートアナライザー法にて測定した。

結果：1）血糖值と 4,8 招よび 12 週間後の $\mathrm{HbA} 1$ 値 の全時点の測定がなされた症例の, 両者には全群で有 意の正の相関が得られたが，全体として4 週後の $\mathrm{HbA} 1$ 值が最も高かった. HbA1c 值も同様であった. 2) 治療法別，年代別に FPG，PPG と 4 週間 $\mathrm{HbA} 1$ 拉 よび $\mathrm{HbA1c}$ 值との相関をみると, 老年群の PPG は, 食事療法拈よび薬物療法のいずれの群も, 若年壮群の FPG，PPG 抢よび老年群 FPG の相関係数に比較する と有意に低值であった. 3) 各群の，4週間後の $\mathrm{HbA} 1$ 值の層別にその血糖值を検討すると, FPG はいずれの 治療法群も全ての層別に扔いて老若間にその平均值抏 よび分散に差はなかったが，PPGは食事療法群で HbA1 7 \%未満抢よび $8 \%$ 台, 薬物療法群で $7 \%$ 未満, $7 \%$ 台抢よび $8 \%$ 台で老年群が若壮年群に比しその平 均值は有意に高值かつ分散も大であった．4） HbA1值 が $9 \%$ 未満で $3 \sim 6$ カ月間のその変動幅が $0.3 \%$ 未満 の症例の 3 回連続した PPG の变動係数は老若間に差 はなかった。

結論：老年者の PPG は，若壮年者 FPG，PPG おょ び老年者 FPG に比して, 変動幅が大きく, その要因に
個人差が示唆された。

248. HbA1c と加歯令および糖尿病罹病期間との関係 朝日生命糖尿病研究所

羽倉 稜子, 飯塚 孝

関口 恵美, 赤沼 安夫

$\mathrm{HbA1c}$ の臨床的意義を解明する一助として, 糖尿病 患者に抢ける $\mathrm{HbA1c}$ に及ぼす加齢, 罹病期間, 糖尿病 治療方法の影響について検討した。

対象は糖尿病外来通院中の糖尿病患者495例(男 333 , 女162)である. HbAlc は HPLC 法, 血糖は多層フィ ルム法で，いずれも耳盈血を用いて測定した。血糖の コントロールは, HbA1c 測定時からさかのぼって, 6 乃至12カ月間に測定した血糖值を指標に区分した。血 糖の総測定回数の $80 \%$ 以上が, $\mathrm{FBG}<120 \mathrm{mg} / \mathrm{d} l$, また は食後血糖 $<160 \mathrm{mg} / \mathrm{d} l$ である場合をコントロール良 とし, 総測定回数の $50 \%$ 以上が, $\mathrm{FBG} \geq 150 \mathrm{mg} / \mathrm{d} l$, 食 後血糖 $\geq 190 \mathrm{mg} / \mathrm{d} l$ である場合をコントロール不良と し，いずれにも該当せぬものをコントロールや，不良 とした。

1. 糖尿病患者を 10 歳毎に区分し, $\mathrm{Hb}$ と HbA1c の 関係をみると, $\mathrm{Hb}$ 抢よび $\mathrm{HbAlc}$ 共に, 老年者に比べ 若年者で, 高值を示すが，40歳代以上で, 比較すると, $\mathrm{Hb}$ は加齢と共に有意に低下したが，HbA1c は不変で あった。しかし, HbA1c は血糖値と強く相関するので, 以下血糖のコントロール別に検討した. 2. 老(65歳以 上), 若 $(30$ - 49歳) 間の平均 $\mathrm{HbA} 1 \mathrm{c}(\%)$ は, コン トロール良群では, 6.8 と6.6, やや不良群では $8.1 と$ 8.1 , 不良群では 9.1 と10.0で注ぼ等しく, いずれの群 でも老・若間に有意差を認めなかった。 3. 罹病期間の 延長之共に, HbAlc は高值を示す傾向にあったが, 治 療法（食事療法, 経口剂, インスリン) ごとに, 罹患 期間 $<10$ 年と 15 年 $\leq の$ 群で検討をしたところ両群間に 差を認めなかった。 4. 罹病期間別に, 各治療法ごとの HbA1cを比較したところ, コントロール良群では罹病 期間に関係なく, やや不良群では, 罹病期間 $<10$ 年の もので, 食事単独療法のものが, 有意に低值を示した。

249. 血糖連続測定による老年者経ロブドウ糖負荷試 験（OGTT）の検討一主として血糖曲線について 日本医大老人科

㴊上 正章, 山下 直博, 春山 勝 西 和紀, 中野 博司, 野崎太矩柌 志賀 幸雄, 大庭 建三, 妻鳥 昌平 


\section{盤若 博司}

目的：糖負荷に対する生体の反応状態をより正確に 把握するために, OGTT の血糖值を連続測定し，その 血糖曲線のパターンと曲線下の面積をもちい, 年代別, 耐糖能別に比較検討した。

方法：対象は，21歳から81歳までの非肥満者38例で ある。耐糖能は, 糖尿病学会勧告値により正常型, 境 界型抢よび糖尿病型に分類し，さらに糖尿病型は，空 腹時血糖值 $140 \mathrm{mg} / \mathrm{d} l$ 未満を $\mathrm{DM} 1$ ，それ以外を $\mathrm{DM} 2$ 群とし，計 4 群に分類した。年代別に，若壮年群（60 歳未満) および老年群 (60歳以上) の 2 群に分類した。 血糖值は持続測定機 (GM1320，京都第一科学社製) を もちい, 75gOGTTをおこない負荷後 3 時間まで 2 分 毎に測定した。

結果：1）血糖値曲線は 1 相性を呈するものおよび 2 相性のものに分類され， 1 相性群は耐糖能別では糖 尿病型に，年代別では老年者に高頻度にみられた。2) 1 相性群の血糖の頂值までの時間は, 正常, 境界, 糖 尿病型の順に遅延し, 境界型群では老年群が若壮年群 に比し遅延する傾向を認めた。 2 相性群では第 1 の頂 值までの時間は若壮年群に扔いて境界型群は正常型群 に比し遅延したが，第 2 の頂值までの時間には耐糖能 別に一定の傾向はなかった.3） 3 時間までの総血糖面 積の検討では， 1 相性群招よび 2 相性群間に各耐糖能 別でいずれも有意の差はなかった。老若いずれも正常, 境界，DM1，DM2群の順に有意に増加したが，老年 DM1群の総血糖面積は若壮年 DM1群に比し有意に低 值であった。

結論：OGTT 時の血糖曲線には耐糖能に関係なく 1 相性および 2 相性を呈するものが存在し， 1 相性は 老年者に高頻度にみられたが，総血糖面積からみると その耐糖能には明らかな差がなかった。境界型 1 相性 群の頂値までの時間は老年群で遅延する傾向を認め, 血糖総面積は, 老年 DM1群は若壮年 DM1群に比し有 意に低值であり，老年者軽度耐糖能異常は若壮年とは 質的に異なる可能性が示唆された。

\section{0. 耐糖能指標と加齢}

高知医大老年病

$\begin{array}{llll}\text { 斎藤 } & \text { 昇, 貞包 } \text { 典子, 松林 公藏 } \\ \text { 三森 } & \text { 倫, 三森 } \text { 康世, 小沢 利男 }\end{array}$

$75 \mathrm{gOGTT}$ による耐糖能患者で FBS と $\mathrm{HbA}_{1} \mathrm{c}$ と の関係では，同時測定の71例で $\mathrm{r}=0.82 ， 1$ 力胸前の FBS との間で $\mathrm{r}=0.88,2$ カ月前の FBS とで $\mathrm{r}=0.76$
であり, $\mathrm{HbA}_{1} \mathrm{c}$ と 1 カ月前の $\mathrm{FBS}$ との間で最も高い 正相関が得られた. 男性の 33 例で $\mathrm{r}=0.84$, 女性の 33 例

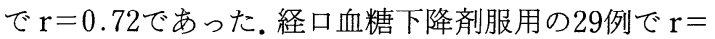
0.83 ，服用なしの35例で $\mathrm{r}=0.89$ で，両者間に差がな かった. 年齢別群では30 49歳の 22 例で $\mathrm{r}=0.87, \mathrm{y}=$ $29.4 \mathrm{x}-51.2\left(\mathrm{y}\right.$ は FBS, $\mathrm{x}$ は $\mathrm{HbA}_{1} \mathrm{c}$ )，50〜59歳の21 例で $\mathrm{r}=0.88, \mathrm{y}=18 \mathrm{x}+17.5,60$ 歳以上の 24 例で $\mathrm{r}=$ $0.85, \mathrm{y}=15.1 \mathrm{x}+37.4$ となり, 関係式の勾配の值が加 齢に上り減少傾向であった。そこで食事療法のみの男 性糖尿病型患者で, $\mathrm{HbA}_{1} \mathrm{c}$ より 1 力月前の $\mathrm{FBs}^{\prime}$ が $110 \sim 129 \mathrm{mg} / \mathrm{d} l$ であった症例に限ると, $\mathrm{HbA}_{1} \mathrm{c}$ の平 均は50歳未満の 9 例で $5.44 \% ， 50$ 歳以上の 18 例て $6.38 \%$ で，50歳以上で有意に高くなっていた。ある範 囲の $\mathrm{FBs}^{\prime}$ では加齢により $\mathrm{HbA}_{1} \mathrm{c}$ が高くなる傾向で あった. $\mathrm{HbA}_{1} \mathrm{c}$ とアポ蛋白 $\mathrm{A}_{1}$ との間で $\mathrm{r}=-0.31$ の 負相関があり，その他の脂質との間では有意の相関は なかった．年齢別では 60 歳以上で $\Delta \mathrm{IRI} / \Delta \mathrm{BS}$ (30分) との間で $\mathrm{r}=-0.61$ の負相関が，脂質摂取量との間で $\mathrm{r}=0.65$ の正相関がみられ, $50 \sim 59$ 歳で脂質摂取量或は 蛋白質エネルギー比との間で負相関 $(\mathrm{r}=-0.36, \mathrm{r}=-$ 0.37)が，糖質エネルギー比との間で $\mathrm{r}=0.41$ の正相関 がみられ，30〜39歳で糖質エネルギー比との間で $\mathrm{r}=$ 0.43 正相関がみられた。59歳未満では糖質摂取割合 と $\mathrm{HbA}_{1} \mathrm{c}$ とが正相関し，60歳以上では脂質摄取量と $\mathrm{HbA}_{1} \mathrm{c}$ とが正相関していた。

以上より耐糖能指標である $\mathrm{HbA}_{1} \mathrm{c}$ は加齢により増 加する傾向もみられる場合もあり, $\mathrm{HbA}_{1} \mathrm{c}$ の判定にあ たりこの点を注意すべきである。

\section{1．高齢者低血糖症の臨床的検討}

都老人医療センター内分泌代謝科

森 聖二郎, 佐藤 忠弘, 藤巻 博

林 純子, 中野 忠澄, 井藤 英喜 同研究検査科白木 正孝, 本山玲子

血糖値 $55 \mathrm{mg} / \mathrm{d} l$ 以下の老年者低血糖症 53 症例につ き, 臨床的検討を加光た。平均年齢76歳（60～91歳）, 男性24例，女性29例であった。

低血糖症状を訴えた症例はわずか 8 例であり，この ちち 6 例は血糖值 $30 \mathrm{mg} / \mathrm{d} l$ 以下であった。しかも，こ れら 6 例中 4 例は, 初発症状として昏睡, 痉攣等の中 枢神経系の症状を呈していた。基礎疾患として糖尿病 が22例あり，全例ともインスリンあるいは経口血糖降 下剂を使用していた。非糖尿病31症例中， 3 例は高力 ロリー輸液中にインスリンを使用していた。残り 28 例 
では血糖降下作用をもついかなる薬郕も使用してはい なかった。これら 28 症例のらちわけは，腫瘍性疾患 12 例，慢性腎不全 3 例，その他 13 例であった。その他の 13 症例中， 2 例は食後の反応性低血糖であったが，残 り11例は空腹時低血糖を呈していた。これら11症例の 基礎疾患は, 慢性閉塞性肺疾患, 脳血管障害等, 低血 糖発症との関連性は考光難かった。これら症例の Body mass index は, 平均 $16.8 \mathrm{~kg} / \mathrm{m}^{2}$ と低值であり, 低栄養状態が低血糖発症の原因ないしは誘因々考兄ら れた。

以上より, 老年者低血糖症の特徵として，1）基礎疾 患として非糖尿病症例の占める割合が比較的多いこ と,2）交感神経系の症状に乏しいこと,が示唆された。 1)の理由として, 腫瘍性疾患, 慢性腎不全などの罹患 率がこの年代で高いこと，また老年者では低栄養状態 にある者が多く，低栄養自体が低血糖発症の誘因さら には原因にすらなりらる可能性があること，なぞが考 号れた。2）の理由として, 糖尿病性神経症の関与, 慢性低栄養状態, 慢性疾患に伴う低血糖症例では, 血 糖低下が比較的徐々に進行した可能性, さらには, 加 齢現象自体に伴い，低血糖刺激に対する交感神経系の 反応が低下する可能性，などが考兄られた。

\section{2. 虚血性心疾患を伴った高齢者糖尿病の臨床像の} 特徵

東京警察病院内科
松浦 誠一, 飯塚 哲司, 松井 浩
井上 清, 藤城 芳子, 鈴木 豊明
後藤 平, 吉川 政己

目的：糖尿病には虚血性心疾患が多く，その心病変 は重篤なものが多いとされているが，最近糖尿病の罹 病期間や重症度は冠動脈硬化と必ずしも関係がないと の報告や，糖尿病に拈ける虚血性心疾患の危険因子に 未知の要因を想定するものもあり, 糖尿病の冠動脈硬 化には，な捈討すべき問題があるように思われる。 虚血性心疾患を伴い易い高齢者の糖尿病において，こ れらの事実の関与を明らかにする目的で, 虚血性心疾 患を伴わない糖尿病を対照として検討した。

対象：昭和 50 年より昭和 59 年までの 10 年間に括ける 当院入院症例のうち, 虚血性心疾患を有する60歳以上 の糖尿病患者 32 例（男 22 例，女10例：平均年歯 $68.0 \pm$ 1.1歳）(A 群）打よびこれと年齢・性・治療法を一致 させた虚血性心疾患のない入院糖尿病患者 32 例 (B 群) である、A 群の虚血性心疾患は, 急性心筋梗塞13例,
陳旧性心筋梗塞11例，狭心症 7 例，虚血性心疾患 1 例 であった。治療別では，食事療法（単独）23例，経口 血糖降下剂 6 例，インスリン療法 3 例であった。

成績：罹病年数 (年); $\mathrm{A}$ 群 $(\mathrm{A}) 8.9 \pm 1.3, \mathrm{~B}$ 群 $(\mathrm{B})$ $8.5 \pm 1.3$, 肥満度 $\left(B M I\right.$, 体重 $(\mathrm{kg}) /$ 身長 $\left.(\mathrm{m})^{2}\right)$; $(\mathrm{A})$ $23.6 \pm 0.7$, (B) $23.3 \pm 0.8$, 空腹時血糖 $(\mathrm{mg} / \mathrm{d} l)$; (A) $169.2 \pm 11.9$ ，(B) $183.1 \pm 13.0$, 血圧 $(\mathrm{mmHg})$; 収縮 期圧 (A) $145.5 \pm 4.7$ ，(B) $140.1 \pm 4.0$, 拡張期圧 (A) $83.6 \pm 2.0$ ，(B) $81.0 \pm 2.2$, 血清総コレステロール $(\mathrm{mg} / \mathrm{d} l$ ) (A) $207.7 \pm 8.4$, (B) $205.1 \pm 7.8$ ，中性脂 肪 $(\mathrm{mg} / \mathrm{d} l$ ) (A) $148.4 \pm 12.7$ ，(B) $132.5 \pm 14.2$, HDLコレステロール $(\mathrm{mg} / \mathrm{d} l)$ (A) $41.0 \pm 2.8$, (B) $47.6 \pm$ 3.5, BUN $(\mathrm{mg} / \mathrm{d} l)(\mathrm{A}) 19.6 \pm 1.3$, (B) $19.4 \pm 1.4$, 血清クレアチニン $(\mathrm{mg} / \mathrm{d} l)(\mathrm{A}) 1.2 \pm 0.1$, (B) $1.2 \pm$ 0.2 , 蛋白尿 (H) 以上, Scott III以上，神経障害など （A）でやや高率であったが有意ではなかった。

まとめ：虚血性心疾患を伴った高㱓者糖尿病の臨床 像は, 虚血性心疾患のない糖尿病と著るしい差はなく, 糖尿病に扔ける虚血性心疾患の危険因子として，遺伝 的要因も含めた未知の因子の関与も否定出来ないと思 われる。

\section{3. 老年者糖尿病と脳梗塞一特に治療法との関連} 浴風会病院

板垣 晃之, 春山 勝, 吉田 亮一

鈴木 孝臣，早川 道夫，大友 英一

$$
\text { 日本医大老人科盤若 博司 }
$$

目的：老年者では特に糖尿病の治療中に低血糖発作 などを契機に脳障害を発症することは以前からしばし ば指摘されている，そこで今回脳梗塞と糖尿病の治療 との関連を Retrospective に検討した。

方法：対象は老人ホーム在住中に50gOGTTを施行 し, 死後剖検し得た男女590例である. 血糖値の判定は 日本糖尿病学会の基準により正常, 境界, 糖尿病型に 分け，正常型と境界型を一括して非糖尿病とした。内 訳は非糖尿病422例, 糖尿病168例で, 糖尿病の治療法 は薬群46例(インスリン 6 , 経口血糖降下剂 40 ), 食事 群122例である。脳梗塞は剖検にて確認された大梗塞 (鷄卵大を越えるもの：以下梗塞と略す)のみを取り上 げた。

結果：梗塞の頻度は非糖尿病 $8.8 \%$ ，糖尿病 $7.7 \%$ で 差異は認めなかった。治療法別では薬群 $19.6 \%$, 食事 群 $3.3 \%$ で薬群は食事群及び, 非糖尿病に比べ有意に高 率であった(それぞれ $\mathrm{p}<0.01, \mathrm{p}<0.02)$. 尚，薬群は 
全例が血糖降下剂服用例であった。そこで以下，血糖 降下剂服用について検討をした。血圧との関連をみる 之, 正常例では, 非糖尿病, 糖尿病, 及び治療法別で の梗塞の差異は認めなかった。高血圧例では非糖尿病 $9.1 \%$, 糖尿病 $8.5 \%$ で差を認めないが, 治療法別では 薬群 $22.9 \%$ で最も高く, 食事群 $3.3 \%$ 及び非糖尿病に比 べて有意に高率であった（それぞれ $\mathrm{p}<0.01, \mathrm{p}<$ $0.02)$. 次に梗塞の発生と血糖降下剂服用開始時年齢及 び，低血糖との関係を見た。開始時年齢が75歳以上の 頻度は梗塞例 $66.7 \%$, 梗塞のない例は $54.8 \%$ で梗塞例 で服用開始時年齢は高い傾向であった。低血糖は梗塞

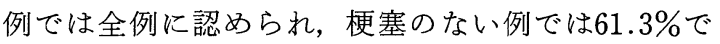
あった。

以上のことから糖尿病例に拈いて脳の大きな梗塞の 発生に糖尿病の治療(特に経口血糖降下剂), 治療開始 時年齢，低血糖，高血圧などの因子が関与している可 能性が示唆された。

254. 老年者糖尿病における感染症死について一剖検 例による検討

$\begin{array}{lll}\text { 都老人医療センター } & & \\ \text { 中野 忠澄, 井藤 } \text { 英喜, 稲松 } \text { 孝思 } \\ \text { 白木 正孝, 藤 博, 中尾 純子 } \\ \text { 佐藤 忠弘, 森 聖二郎, 嶋田 } \text { 裕之 } \\ \text { 東大老年病 } & \text { 折茂 肇 }\end{array}$

目的：老年者に扮ける糖尿病と感染症死との関係 を，剖検例を用いて検討することを目的とした．

方法：対象は，耐糖能を知り光た60歳以上の老年者 剖検例404例 (男198例，女206例，平均年齢77.1歳）で あり,これら対象を日本糖尿病学会の勧告值に準じて, 耐糖能正常型群 ( $\mathrm{N}$ 群, 35例), 境界型群 (BL 群, 184 例）扣よび糖尿病型をた糖尿病の群（DM 群，185例） の 3 群に分けた。これら 3 群に抢ける臨床成績および 病理所見（直接死因ならびに主要背景疾患）につき, 比較検討した。

結果：(1)直接死因が感染症であった（感染症死）症 例は, $\mathrm{N}$ 群で12例 (34\%)， BL 群で64例 (35\%)，DM 群で54例（29\%）と，いずれの群の間にも，頻度に有 意差は認められなかった. (2) BL 群および DM 群にお ける感染症死例の血清総コレステロールおよび中性脂 肪は，悪性腫瘍死例のそれらに比し低值であった。(3) 感染症死の内訳をみると, 呼吸器感染症 (肺炎, 肺結 核) 死例は， N 群10例 (感染症例中 $83 \%$ ), BL 群50例 (42\%)，DM 群35例（65\%）といずれの群においても
高率であったが, 各群の頻度に有意差を認めなかった。 (4)尿路感染症 (腎孟腎炎) 死例は，N 群ではみられず, $\mathrm{BL}$ 群 5 例 (8\%), DM 群 7 例 (13\%) と DM 群で高 率の傾向がみられた。 (5)敗血死も， N 群 1 例 ( $3 \%$ ), BL 群 5 例 ( $8 \%)$, DM 群 9 例 (17\%) とDM 群で高 率の傾向がみられた。(6)感染症死例の主要背景疾患の 頻度は， $\mathrm{N}$ 群および $\mathrm{BL}$ 群のいずれにおいても，呼吸 器感染症死例々尿路感染症死例々の間に有意差を認め なかった。一方，DM 群に抢ける感染症死例の主要背 景疾患のうち, 血管障害は, 呼吸器感染症死例に损い て尿路感染症死例に比し，また尿路感染症は，尿路感 染症死例において呼吸器感染症死例に比し，それぞれ 有意に高率であった。

結語：感染症の多発する老年者に抢いても，糖尿病 は, 感染症死に対し，一定の意義を有することが示唆 された。

\section{5. 老年者糖尿病性神経障害の治療に関する研究} （第 1 報）漢方製剤（TJ107）と $\mathbf{V B}_{12}$ の比較検討試験

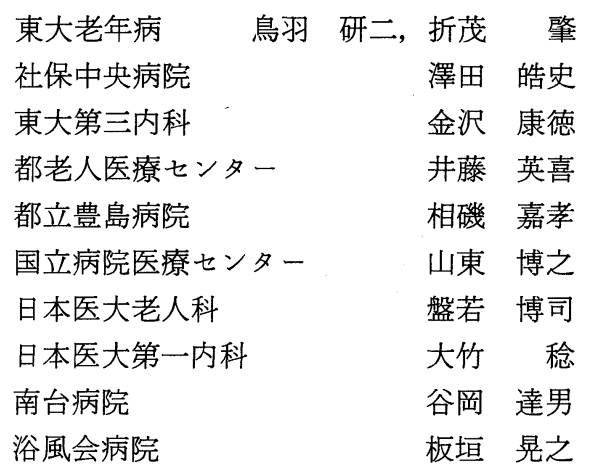

糖尿病性神経症は DM triopathy 中最も高い頻度で みられ, 生死に関わらない場合でも, 患者の苦痛は大 きく臨床上有効な薬剤の出現が切望されている.

目的：糖尿病性神経症に対して漢方製剂 (TJ107) と $\mathrm{VB}_{12}$ とを投与し, その自他覚症状の改善度を比較検討 する.

対象及び方法：当科及び各施設の外来通院患者で, 神経症を有する DM 患者57名（平均65.3歳）に対し封 筒法により投与薬剤を決定し, 投与前 4 週及び投与後 8 週迄，自他覚所見を追跡した。

結果：患者の背景因子である罹病期間, 治療方法, コントロール状態, 合併症などに両群間に差はなく, 又年齢, 性, 血糖, $\mathrm{HbA}_{1}$, 血圧などにも差を認めなかっ た。治療前の自覚症状の発現率も両群でよく近似して いた。 又神経学的所見も両群間で差がなかった。投与 
後, 血圧, 血糖, $\mathrm{HbA}_{1}$, や血液生化学所見に両群之も 变化はなく, 又他覚神経所見の改善も認められなかっ た。自覚症状のらち，しびれ，冷感，注てり，下肢痛， 脱力などに対し, TJ107群が改善度が高かった. 改善度 と年齢との間には相関を認めなかった一方頻尿, 便秘 などの自律神経症状に対しては，VB $\mathrm{VB}_{12}$ 群の改善度が 勝っていた。

考察：最近糖尿病性神経障害に関してポリオール代 謝系路が重要視されて打り，その律速酵素であるアル ドースリダクターゼに対し漢方製剂の阻害効果が報告 されている，これらの成績を考慮し，今回我々はアク ティブプラセーボと漢方製剤と比較検討した結果，特 に下肢のパレステジアと思われる自覚症状の軽減効果 が漢方製剂に於て予想以上に得られた。この機序の詳 細は尚今後の検討を要すると思われるが，比較的早期 より改善効果が出現していることょり，鎮痛作用や循 環改善作用がその一因々考学られる。両薬剤が異なっ た自覚症状の改善を示したことは，両者の併用療法も 今後検討課題と考兄られた。

\section{6. 老年者糖尿病性神経障害の治療に関する研究} （第 2 報）漢方製剤の証の再検討

$\begin{array}{lrr}\text { 東大老年病 鳥羽 } & \text { 研二, 折茂 } & \text { 肇 } \\ \text { 東大物療内科 } & \text { 菊谷 } & \text { 豊彦 } \\ \text { 東大第三内科 } & \text { 金沢 } & \text { 康徳 } \\ \text { 都老人医療センター } & \text { 井藤 } & \text { 英喜 } \\ \text { 都立豊島病院 } & \text { 相磯 } & \text { 嘉孝 } \\ \text { 国立病院医療センタ- } & \text { 山東 博之 } \\ \text { 日本医大老人科 } & \text { 盤若 } \text { 博司 } \\ \text { 日本医大第一内科 } & \text { 大竹 稔 } \\ \text { 南台病院 } & \text { 谷岡 達男 } \\ \text { 浴風会病院 } & \text { 板垣 } & \text { 晃之 } \\ \text { 社保中央病院 } & \text { 澤田 皓史 }\end{array}$

糖尿病性神経症は糖尿病患者に高頻度に合併し，そ の苦痛は小さくない，その多岐にわたる症状が牛車腎 気丸証と合致する点が多いことから治療効果を検討し 「証」の見直しの必要性について若干の知見を得たので 報告する。

対象と方法：当科及び各施設に外来通院中の症状の 安定した老年者糖尿病患者（40～89歳，平均65.4歳） で神経症状を有するものを対象とした。投与前 4 週間, 投与後 8 週間を観察期間とし，自覚症状，他覚所見を 追跡し，更に漢方証に照らしてその症状，所見が，牛
車腎気丸の証に合致しているかどらかを，漢方専門医 が判定した。自他覚所見について，得点化を行い，改 善度，重症度を加味して「証」及び「非証」の合理性 について検討を加光た。

結果：(1) 得点化の合理性の検定, 投与前の糖尿病 性神経症の重症度（高度, 中等度, 軽度) と得点とは 有意の相関 $(\mathrm{p}<0.05)$ が得られ，一定の合理性がある と考兄られた。（2）証に準ずる（証に近い）症状，所 見のうち，しびれ感，下肢痛，下肢脱力感，反射低下， 振動覚減弱などについては症状を明確にもつもの程, 改善が認められたのに対し, 夜間頻尿, 口渴, 多尿, 全身倦怠感などには，一定の傾向が認められず，又従 来非「証」とされるほてり感に効果があった。「証」と 非「証」との比を改善度に対して検討したところ，有 意性は得られず， ほてり感を新たな証に加えると，改 善度との相関が有意 $(\mathrm{p}<0.05)$ であった。（3）肥満度 との検討・肥満者に効果がつよい傾向が得られ, 従来 の証の考えに反していた。

考案：漢方証は特定疾患と因果関係をもった自他覚 所見とは必ずしも一致しないことより，同病異証或い は異病同証といら現象が出現する。漢方薬剤の厳密な 適応を疾患別に行らために，他の疾患についても今回 のよらな試みの必要性が示唆された。

\section{7. プロラクチン（PRL）分泌反応性に及ぼす加齢 の影響}

聖マリアンナ医大神経精神科 根岸協一郎, 青葉 安里, 山口 登 常泉 智弘, 高木 博敬, 千嶋 達夫 酒井隆, 廿楽 通徳, 紫藤 昌彦 長谷川和夫

目的：プロラクチン (PRL) の分泌反応性に及ぼす 加齢の影響を検討する目的で，正常被検者に打ける血 浆中 PRL 值の定量及び，抗ドーパミン作用を有する 三環系抗らつ成である Amoxapin(AMX)を服用中の らつ病患者を対象とし, 血浆中 PRL 值と, AMX の血 浆中 neuroleptic level (NLL) の測定を行った.

対象：正常被検者 17 名（男 9 名，女 8 名）平均年齢 は $49 \pm 23.1$ ，その年齢分布は $21 \sim 80$ 歳であった。一方 AMX にて治療中のうつ病患者 20 名 (男 8 名, 女 12 名) 平均年齢は $45 \pm 20.2$ ，その年齢分布は $21 \sim 68$ 歳であっ た.

方法：正常被検者に対して, 採血を午前10時に行い, 血奨中 PRL 值の定量を行った. PRL 値の測定には 
RIA 法を用いた。らつ病患者に対して採血は同様に行 い血浆中 PRL 值と AMX の血浆中 NLL の測定を 行った. PRL 值の測定には RIA 法, AMX の血浆中 NLL の測定には RRA 法を用いた。

結果：(1)血奨中 PRL 值は加齢に伴って低下傾向を みたが，有意な相関は認められなかった $(\mathrm{r}=-0.38$, NS). (2)血浆中 PRL 值は AMX 血浆中 NLL 依存的に 上昇し両者間に有意な相関が認められた $(r=0.6, p<$ 0.01). (3) AMX による PRL 分泌反応性 $(\mathrm{P}-\mathrm{N}$ 比) 恃, 加歯に伴い低下することが認められた $(\mathrm{r}=-0.40, \mathrm{p}<$ 0.05).これまで, PRL 分泌細胞の加齢に上る形態的 な変化は認められないと報告があり（Kovacs K.et al. J.Gerontology, 32:534-540, 1977), 本研究で認め た AMX 負荷による PRL 分泌反応性の加齢による低 下は, PRLの下垂体分泌調節機構の加龄による低下を 直接反映したものと思われる.

\section{8. 健常人および高血圧患者の血浆レニンに及ばす 加齢の影響}

阪大老人科

檜垣 實男, 荻原 俊男

中丸 光昭, 熊原 雄一

目的：新しく開発されたヒト血浆レニン酵素の直接 ラジオイムノアッセイ(RIA)法を用い健常人及び高血 圧患者の血浆レニン濃度を測定し，加齢の血中レニン に及洔す作用を解明するとともに，老年者高血圧症の 血浆レニン動態の特徵についても知見を得る.

方法: 健常人 24 名, 高血圧患者 18 名に括いて, 常食 下，臥位 30 分後に採血を行なった。血浆はー $30^{\circ} \mathrm{C} に て$

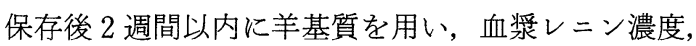

トリプシン処理による総レニン濃度, さらに直接 RIA 法によるレニン濃度を同時測定した。

結果：直接 RIA 法によるレニン濃度は健常人60歳 未満で $1.5 \pm 0.1 \mathrm{ng} / \mathrm{m} l$ (mean $\pm \mathrm{SED})$ であり，健常人 60 歳以上では $1.1 \pm 0.03 \mathrm{ng} / \mathrm{m} l$ に低下した $(\mathrm{p}<0.05)$. 高血圧患者では 60 歳未満 $1.5 \pm 0.15 \mathrm{ng} / \mathrm{m} l, 60$ 歳以上 $1.3 \pm 0.06 \mathrm{ng} / \mathrm{m} l$ で有意の低下を示さなかった．総レ ニン濃度は健常人 60 歳未満で $14.1 \pm 1.5 \mathrm{ng} / \mathrm{ml} / \mathrm{hr}, 60$ 歳以上では $8.2 \pm 1.0 \mathrm{ng} / \mathrm{m} l / \mathrm{hr}$ に低下 $(\mathrm{p}<0.05)$ した が, 高血圧患者では有意の低下を示さなかった。An一 giotensin I 産生能による血浆レニン濃度は健常人 60 歳未満 $4.5 \pm 0.8 \mathrm{ng} / \mathrm{m} l / \mathrm{hr}$. 60 歳以上 $1.5 \pm 0.2 \mathrm{ng} / \mathrm{ml} /$ $\mathrm{hr}$. 高血圧患者 60 歳未満 $3.0 \pm 0.5 \mathrm{ng} / \mathrm{m} l / \mathrm{hr}, 60$ 歳以上 $1.6 \pm 0.1 \mathrm{ng} / \mathrm{m} l / \mathrm{hr}$ で, 健常人, 高血圧患者のどちらも 加齢により有意の低下 $(\mathrm{p}<0.05)$ を示した。
考察: 加齢により血奨レニン濃度, 総レニン濃度, レニン RIA によるレニン濃度のいずれも健常人で低 下したことから，健常人では加齢によりレニン分泌が 低下すると考学られる，高血圧患者に打いては加齢に より血浆レニン濃度のみ低下を示し, 総レニン濃度と 直接 RIA 法によるレニン濃度は有意に低下しなかっ たことから，老年者高血圧症に括けるレニン動態の異 常, 特にプロレニンからレニンへの転換障害が示唆さ れた。

259. バセドウ病における血清アルカリフォスファ ターゼ活性 (ALP) の加跉変化

信州大老年科雪村八一郎, 相澤徹 石原 雅樹, 山田 隆司

バセドウ病による骨吸収の促進は骨新生を結果とし て促進するため, 血中アルカリフォスファターゼ活性

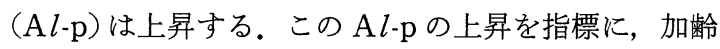
のバセドウ病による骨変化に及ぼす影響を検討した。

方法：未治療バセドウ病患者139名（12７9歳），を 対象とし, 治療前, 抗甲状腺剤による治療中, 及び甲 状腺機能が正常化して 2 年後の状態を対照群と比較し た。

結果：(1)治療前バセドウ患者は各年齢層とも対照群 より $\mathrm{A} l \cdot \mathrm{p}$ が高值を示したが加齿命と共にその上昇の程 度が軽減した (10代135対179，20代56対151，30代59対 $125 ， 40$ 代 59 対 $123 ， 50$ 代 74 対 $127 ， 60$ 代 67 対 $111 ， 70$ 代 71 対 110 , 各 $\mathrm{U} / \mathrm{L}$, 平均值, 対照対患者). 血中 $\mathrm{T}_{3}$ 值 加齢と共に低下しているため $\mathrm{A} l-\mathrm{p} / \mathrm{T}_{3}(\times 1,000)$ を計 算してみると 10 代 $331 ， 20$ 代 $347 ， 30$ 代 $255 ， 40$ 代 279 , 50 代 $386 ， 60$ 代 $421 ， 70$ 代 680 ， と30歳代を底として以後 加歯とともに漸増した。 (2)治療後 $75 \%$ の症例で血清 $\mathrm{A} l$-P は治痛前の $10 \%$ 以上の上昇を示し，その頂值は 治療開始後 $8 \sim 16$ 週にあった。この間血中甲状腺ホル モン值, $\mathrm{Ca}$ 值はともに漸減して招り, $\mathrm{A} l$-p の再上昇は 骨の治療過程を反映しているものと考学られた。この 現象を年齢別にみてみると, $\mathrm{A} l$ - $\mathrm{p}$ の一過性上昇は 10 代 $67 \% ， 20 ４ 0$ 代 $74 \% ， 50$ 代以降 $85 \%$ ，と加齢と共にそ の頻度が上昇していた。 (3)治療後 2 年以上経過した時 点では全年齢層とも血中 $\mathrm{A} l$-p は対照群と同じレベル に低下した。

考察：高齢のバセドウ病患者では血清 $\mathrm{A} l$ - $\mathrm{p}$ の絶対 值の上昇の程度は軽度であるが $\mathrm{A} l-\mathrm{p} / \mathrm{T}_{3}$ 比は上昇し て和り, 甲状腺機能六進の程度に比して骨吸収が促進 している可能性が大きい, 又, 治療後一過性に血清 
$\mathrm{A} l$-P の上昇する頻度が高く, 治癒過程の遷延してい る事を示唆した。

結論：高齢なバセドウ病患者では血清 $\mathrm{A} l$-p の上昇 の程度は軽いが，骨障害の程度は必ずしも軽くなくそ の治癒に時間を要する例が多い。

\section{0. 老年者における甲状腺機能の病態生理学的研究} 札幌医大第一内科

佐藤美也子, 上條 桂一
川崎 君王, 谷内 昭

目的：老年者に扮ける栄養状態, 知的精神機能, performance status と甲状腺機能の関係を研究すること により，老年者に扔ける甲状腺機能異常を病態生理学 的に追究せんとした。

方法：正常対照群109例（内訳は若年者41例，老人 ホーム居住の健常老年者69例）と，60歳以上の癌，本 態性高血圧症, 冠動脈硬化症, 脳梗塞等の老年者患者 136例を対象とした。栄養状態は体重減少を指標とし， 知的精神機能は長谷川式スケールを用い, performance status は小山・斉藤の分類を用い甲状腺機能と の関係を検討した。血中 $\mathrm{T}_{3}, \mathrm{~T}_{4}$ は RIA を用いて測定 した。 また $\mathrm{T}_{3} / \mathrm{T}_{4}$ 比が実際の $\mathrm{T}_{4}$ から $\mathrm{T}_{3}$ への変換率と 高い相関 $(r=0.92, \quad \mathrm{p}<0.01)$ を示すことから，指標 として用いた。

結果：正常対照群に抒いては $\mathrm{T}_{3}, \mathrm{~T}_{4}, \mathrm{~T}_{3} / \mathrm{T}_{4}$ 比共に 加齢に伴う变化は認められなかった。老年者癌患者で は，10\%以上の体重減少を示した群で，10\%未満の体 重減少群に比べ血中 $T_{3}, T_{3} / T_{4}$ 比が有意 $(\mathrm{p}<0.01)$ の 減少を認めたが，59歳以下の若年者癌患者では，体重 減少の程度と甲状腺機能々の間に有意の相関は認めな かった．また体重減少が $4 \%$ 以下の癌及び他の疾患の 老年者患者に沏いて長谷川式スケールと血中 $\mathrm{T}_{3}$ 值, $\mathrm{T}_{3} / \mathrm{T}_{4}$ 比とはそれぞれ $\mathrm{r}=0.48,0.45$ で有意 $(\mathrm{p}<0.01)$ の相関を示した。同一対象において, performance status との関係では血中 $T_{3}$ 值が全身状態の変化に伴 い低下傾向を示したが, grade 4 では 0 及び 2 に比較し て有意差 $(\mathrm{p}<0.01)$ が認められ，また血中 $\mathrm{T}_{3} / \mathrm{T}_{4}$ 比に おいては，grade $3 ， 4 て ゙ 0$ に比較して有意 $(p<0.01)$ に低值を示した。

結論：(1)正常対照群に扮いては末梢に扮㚈る $\mathrm{T}_{4}$ か ら $\mathrm{T}_{3}$ への変換，すなわち5'-脱ヨード反応は加齢によ る変化を認めなかった。 (2)低栄養状態での $\mathrm{T}_{3}$ 産生に与 える影響には年齢差のあることを明らかにした。(3)長 谷川式スケールと血中 $\mathrm{T}_{3}$ 值, $\mathrm{T}_{3} / \mathrm{T}_{4}$ 比の間に有意差を
認めたことから，老人性痴呆に $\mathrm{T}_{3}$ が何らかの役割を 担っていることが推測された. (4) performance status の変化に相関して血中 $\mathrm{T}_{3}, \mathrm{~T}_{3} / \mathrm{T}_{4}$ 比が変化することを 示した.

\section{1. 膵・消化管ホルモン含量に及ぼす加齢の影響 京大第二内科}

过和雄, 石田 均, 北野 則和

津田 謹輔，井村 裕夫

同病態栄養部清野裕, 田港 朝彦

都老人医療センター 井藤 英喜

目的：組織中の荤・消化管ホルモン含量に及ぼす加 齢の影響をラットを用いて検討した。

方法：Wistar 系雄性ラット（月齢 6 及び25M）の消 化管（胃・十二指腸 -上部小腸 -下部小腸 - 大腸），膵 および脳より $2 \mathrm{~N}$ 酷酸にて somatostatin(SS)，GIPを 抽出しその含量をRIA にて測定した。膵については insulin, PP も測定した。

結果：(1)膵掞よび消化管各部の SS 含量：㬸の湿重

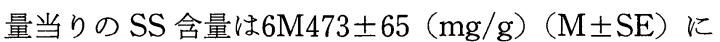
対し $25 \mathrm{M}$ では $277 \pm 36$ と有意 $(\mathrm{p}<0.05)$ の低值がみら れたが，蛋白量当りでは有意差はみられなかった。胃 では湿重量当り $6 \mathrm{M}$ ラットで $675 \pm 58,25 \mathrm{M}$ で $372 \pm 45$ 之有意に低下し $(p<0.01)$, 蛋白量当りにても同様で あった。また下部小腸，大腸にても湿重量当りで，6M の各々 $119 \pm 5,135 \pm 12$ に対し， $25 \mathrm{M}$ では $90 \pm 5,72 \pm$ 9 と共に有意の低值を示し $(p<0.01)$, 蛋白量当りでも 同様であった。また脳を前頭葉，小脳等 9 つに分割し 各部の SS 含量を測定したが, 湿重量および蛋白量当 り共, 加齢による SS の变化はみられなかった。 (2)消化 管の GIP 含量：GIP は膵, 胃, 大腸掞よび脳には認め られなかった。十二指腸では加歯による GIP 含量の差 を認めなかったが, 上部及び下部小腸では湿重量当り, $6 \mathrm{M}$ の各々 $911 \pm 58,518 \pm 98(\mathrm{ng} / \mathrm{g})$ に対し， 25M で

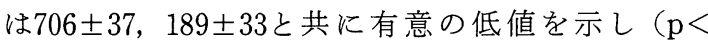
0.01), 蛋白量当りでも同様であった. (3)膵 insulin, PP 含量：共に加齢による変化はみられなかった。

考察：今回の成績より膵及び消化管のソマトスタチ ンは加齢とともにその含量が低下した。したがって加 歯领に伴って進行する糖代謝異常の一因としてソマトス タチンの減少によるインスリンやグルカゴン分泌の抑 制の低下や，消化管よりの栄養素の吸収抑制の低下な ぞの関与が推測された。加軨により GIP は低下したが その意義はな扮明らかでなく今後検討を要する。 
262. ブロムペリドールの血浆中レベルおよびその薬 効に及ぼす高齢者の身体機能の影響

聖マリアンナ医大神経精神科

千嶋 達夫, 青葉 安里, 山口登

常泉 智弘, 酒井 隆, 根岸協一郎

高木 博敬, 廿楽 通徳, 紫藤 昌彦

長谷川和夫

都老人総合研究所臨床第一生理

木谷 健一, 柴田 牧子

目的：ブチロフェノン系の抗精神病薬ブロムペリ ドールを高齢者に投与し，アルブミンを指標とした身 体的有病性が薬物代謝和よび副作用出現に関し，どの よらな関連を有するかについて検討した。

対象: 老人病院入院中の患者で, せん妄, 不眠, 精 神運動興奮などの標的症状を有するもの 20 名(女18名, 男 2 名, 年齢 $72.8 \pm 10.3$ 歳).

方法：標的症状に対してブロムペリドールを投与 し, Steady state に達する 1 週後より 1 週拈きにその 血浆中レベルを Radio-receptor Assay により測定し, 測定値を Neuroleptic Level（NLL，nM）として表わ した。同一サンプルより血清アルブミン值を $\mathrm{BCP}$ 法 により測定した。採血の行なわれた時点で標的症状に 対して効果のあった状態を Responsive State，効果の なかった状態を Non-Responsive State, 副作用のため 投与中止あるいは減量を必要とした状態を Adverse Drug Reaction と効果判定を行った.

結果：血浆中 NLLを体重当り 1 日投与量で割った 值, Plasma Level Dose Ratio (P-D 比) を各薬効群 で比較したところ, Adverse Drug Reaction では, 他 の 2 群に比べて有意な高值を示した $(\mathrm{p}<0.01)$. 一方 P-D 比と血清アルブミン值との間の有意な負の相関を 認めた $(\mathrm{p}<0.01)$.

考察：Adverse Drug Reaction の出現時点での肝臓 でのブロムペリドール代謝能の低下が示唆され，血清 アルブミン值が間接的であれ，薬物代謝能の指標とな り, Adverse Drug Reaction 出現を予測する上で有用 と考觉られる。

263. プロペリシアジンの血浆中レベルの变動に及ぼ す高齢者の身体機能の影響

聖マリアンナ医大神経精神科

酒井隆, 青葉 安里, 山口登

常泉 智弘, 千嶋 達夫, 根岸協一郎
高木 博敬, 甘楽 通徳, 紫藤 昌彦 長谷川和夫 都老人総合研究所臨床第一生理

木谷 健一, 柴田 牧子

目的：高齢者の精神症状（不眠，せん妄，徘徊）に 対してフェノチアジン系の向精神薬であるプロペリシ アシシンを投与し，血浆中薬物濃度の経時的測定（10日 ～200日)を行い, その肝代謝能の経時的変動に及ぼす, 感染及び運動機能の影響について明らかにすることを 目的とした。

対象と方法：老人内科入院中の 31 名の高齢患者（男 性 9 名女性 22 名, 年齢80.1 18.95 歳, Mean \pm SD）を 対象とし, 精神症状に対しでプロペリシアジンを 1 日 1 回, 5 20mg の範囲内で単剂投与し, その血浆中濃 度を最長 200 日にわたり約 10 日間隔で経時的に測定し た。測定方法は ${ }^{3} \mathrm{H}$-Spiroperidol を標識物質とした radioreceptor assay 用い, 測定値は neuroleptic level（nM）として表した.

対象患者の感染の指標として血清 CRP 值, 運動機 能の指標として, GBS スケールの内運動機能の項目を 用いた。また，プロペリシアジン，薬物代謝能の指標 として, 血浆中 neuroleptic level を体重当りの一日投 与量で割った值 (Plasma level dose ratio ${ }^{\mathrm{m}} \mathrm{M} / \mathrm{mg}$ / $\mathrm{kg}$ ）を用いた。

結果：GBS スケールにて運動機能が低下し $(>20)$ かつ CRP 值が陽性を示した群は, 運動機能が保持さ

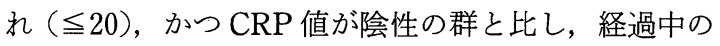
Plasma level dose ratio が有意な高值 $(\mathrm{p}<0.01)$ を 示し, かつ変動幅に有意な差 $(\mathrm{p}<0.01)$ を認めた。

これらの結果より, 感染を初めとした身体機能が低 下し, 運動機能の低下している高齢者においては, 肝 での薬物代謝能が低下し, かつその変動幅が著しいこ とが示唆された。典型的症例をともに報告する。

\section{4. 老年者の呼吸機能の評価に関する検討}

都老人医療センター研究検查部
米山美智子, 向山 敏夫
同呼吸器科

松香 裕子, 水内 知子, 増山 英則 松井 玲子, 松瀬 健, 木田 厚瑞

目的：春柱変形を有する患者では，身長が低下する ため, 肺活量の予測值に最大 $23 \%$ の誤差を生じ得ると いう報告（Hepper N.G.G. 1965）がある。老年者の脊 柱後弯も, 身長の低下を招き, 呼吸機能の予測值に影 
響する可能性がある，本研究では，老年者の呼吸機能 を評価する際，身長の低下が大きな誤差の原因となり 得るか否かを検討した。

対象及び方法：昭和60年11月ょり 6 カ月間に東京都 老人医療センターで呼吸機能検査を実施した 600 名か ら, 明らかな心肺疾患がなく, 肺活量 (VC) 1 秒量 $\left(\mathrm{FEV}_{1.0}\right)$ とも当センターの正常值を満足した 91 名を 対象とした。呼吸機能検査は，日本光電社製 MFR8510 を使用し，検查時に身長 $(\mathrm{Ht})$ ，Arm span（As）を通 例飞従って計測した。胸部 X 線側面像より, Fon （1980）の方法で hyphotic angle（XY-p）を測定した。

結果： VCは Ht とも As ともよく相関し, その程度 に差は見られなかった。 又, As と Ht の差 (As-Ht) や比 $(\mathrm{As} / \mathrm{Ht})$ は，年齢や KY-p と相関しなかった。 $\mathrm{As} / \mathrm{Ht}$ の平均值は男性で1.029, 女性で1.026であり As Boldwin の式に代入しても，誤差は平均 $3 \%$ で あった. As-Ht の最大值は $11 \mathrm{~cm}$ だが，この差の身長に 対する比は $7 \%$ となり，同様に肺活量の予測值の誤差 は $7 \%$ \%内にとどまった。

考察及び結論：身長とArm span の解離は，必ずし も春柱の後弯々関連せず，身長の低下には股関節や膝 関節の伸展不良なども考号られ，若年者の高度の後側 弯症に比し，全体に程度も軽く過去の報告に見るよう に必ずしも身長を Arm span で補正する必要はないと 考兄られた。 以上より，加齢に伴う身長の低下は，呼 吸機能の評価に際し無視し得る事が示唆された。また 起立不能な老年者の呼吸機能を評価する際，身長の代 りにArm span を代用し得る可能性がある。

\section{5. 高齢者に於ける尿中総ポリアミン測定の意義} 熊本大中検 岡部 紘明 都老人医療センター

村井 容子, 木田 厚瑞, 森 真由美 橋本 肇, 野間 昭夫

癌の生化学的検査指標として尿中総ポリアミン測定 の評価は近年見直されて来た。臨床検查の立場での生 化学的指標之考光る場合, 正常人, 癌患者, 非癌患者 の 3 群に厳密にコントロールされた分析が必要であ る. 年齢, 性別, 健康状態, 又病歴及び治療等も考慮 に入れ，癌の診断法を正しく評価する母集団を選ぶ事 は実際上極めて困難である。我々は都内老人ホーム在 住の健康高齢者（60歳以上）集団中から発生した種々 の癌患者を中心として検討し, 又治療中の変動及び他 の癌マーカーとの関係についても比較検討したので報
告する，尿中総ポリアミンは $\mu \mathrm{M} / \mathrm{g}$ creatinine 当で表 現し, 酵素法で測定した。又従来法との比較は HPLC 法により測定した。

結果：健康高齢者群での值は統計的に正規分布を示 さず，又女性は男性よりも高值を示した，異常值の出 現頻度は女性に多く，加齢と共に増加して行った。外 来での無作為抽出で測定した中で異常高値を示した大 部分は癌患者であったが, 非癌患者では肺炎, 肝硬変, 胃潰瘍，脳血管障害等で高値を示す例があった，癌患 者では, 術後では直後に増加傾向を示した。再発ほど の増加は示さなかった。血液癌では投薬後に増加傾向 を示すが，逆に低下する例も有った。肺癌では一度減 少し, 又増加する 2 峰性が認められ, 経過観察が必要 である。 $\alpha$-FP, CEA, Ferritin, $\beta_{2} \mathrm{MG}$ と PA との診 断上の比較を肺癌の症例で見ると, 確定診断され又, 治療中のものを含め69例中 PA 陽性は約38\%で, 他腫 瘍マーカーも同様で， $\alpha$-FP 以外は著明な違を認めな かった。陽性率の高い順としては Ferritin, PA, CEA の順であったが, $\beta_{2} \mathrm{MG}$ では凝陽性率の出現頻度が高 かった。

\section{6. 上腕動脈波記録計の臨床的有用性一高齢者に対 する応用}

千葉大第三内科

関谷貞三郎，佐野 孝彰，古川洋一郎

清水正比古, 富谷 久雄, 外岡 正英

斉藤 俊弘, 稲垣 義明

通常の血圧測定操作で上腕動脈脈波 (BPW) b記録 でさるよう開発された上腕動脈脈波記録計を使用し， 高齢者を対象として，得られた BPWをとの波形上の 特徵により 0, I, II, IIIの 4 型に波形分類を行ない 血行動態との関係について検討した.

対象技よび方法：60歳以上の高齢者70名（正常血圧 45名, 高血圧25名)を対象とし，血行動態指標として, 同時記録した頝動脈脈波と上腕動脈脈波とから算出し た脈波速度，色素稀釈法による心拍出量と平均血圧よ り求めた全末梢抵抗および 1 回心拍出量を脈圧で除し て求めた值を血管伸展性の示標として用いた。な扮数 値は平均値士標準誤差で示した。

結果：年齢が増すにつれて 0 型 I 型は減少し, II 型, III型の増加する傾向が認められた。 また, 高血圧群 $(\mathrm{H}$ 群）と正常血圧群（N 群）とを比較すると $\mathrm{H}$ 群でIII型 の占める割合が大であった。（H 群60\%，N 群17.8\%） 各波形分類と血行動態との関係をみると,脈波速度は, 
0 型 $708 \pm 10 \mathrm{~cm} / \mathrm{sec}, \quad$ I 型 $742 \pm 10 \mathrm{~cm} / \mathrm{sec}, \quad$ II 型 $862 \pm$ $28 \mathrm{~cm} / \mathrm{sec}$, III型 $982 \pm 47 \mathrm{~cm} / \mathrm{sec}$ であり, 全末梢抵抗は 0 型 $1,760 \pm 50 \mathrm{dyne} \cdot \mathrm{sec} \cdot \mathrm{cm}^{-5}$ (以下単位同じ) I 型 $1,910 \pm 120$, II 型 $2,230 \pm 110$, III型 $2,840 \pm 130$ であっ た。ささらに血管伸展性との関係は，0 型 $1.7 \pm 0.1 \mathrm{~m} l /$ $\mathrm{mmHg}$, I 型 $1.5 \pm 0.2 \mathrm{ml} / \mathrm{mmHg}$, II 型 $1.3 \pm 0.2 \mathrm{ml} /$ $\mathrm{mmHg}$, III型0.9土0.1m $\mathrm{l} / \mathrm{mmHg}$ であった.すなわち, 脈波速度が速く，全末梢抵抗の増大しているものある いは血管伸展性の低下しているものではIII型を示すも のが多い結果であった。

屯とめ：上腕動脈脈波記録計により分類した波形パ ターンは, 脈波速度, 全末梢抵抗抢よび血管伸展性を 反映していることが示唆された。

\section{7. 振動障害患者の検查成績の 5 年経過と加跉の影 響}

北大登別分院内科

$$
\begin{aligned}
& \text { 藤屋 秀一, 浅沼 義英 } \\
& \text { 井出 肇, 阿岸 祐幸 }
\end{aligned}
$$

目的：振動障害患者 (VD と省略する)の検査成績の 多くは年齢との相関が認められ，加齢の影響を受ける と考学られている。従って検査成績の長期経過を検討 する際には，加龄の影響を把握する必要があるが，こ れまでそうした分析は行われてこなかった。我々は $\mathrm{VD}$ の検査成績の 5 年経過を年齢因子との関連におい て検討した。

方法：対象はVD50名 (平均年齢54土標準偏差 7 歳) である.VDの検査としては握力, つまみ力, タッピン グ回数 (10秒, 30 秒), 痛覚域値, 振動覚域值, 常温下 及び冷水負荷後の手指皮膚温を毎年 1 回， 5 年間にわ たり測定した。検査成績の経年変化は, 年度との順位 相関係数 (Spearmanの r) を求め, 有意の相関を認め た場合に悪化または改善と判定した。検査成績の 5 年 経過に及ぼす加齢の影響は, 各成績を従属变数, 年齢 を共変量, 検査年度を要因として, 一元配置分散・共 分散分析を行い検討した。

結果：検查年度と有意の順位相関を認めた検査成績 は, 握力 $(\mathrm{rs}=-0.184, \mathrm{p}<0.005)$, つまみ力 $(\mathrm{rs}=-$ $0.121, \mathrm{p}<0.05)$, 痛覚域値 $(\mathrm{rs}=0.250, \mathrm{p}<0.001)$, $125 \mathrm{~Hz}$ 振動覚域值 $(\mathrm{rs}=0.169, \mathrm{p}<0.01)$ などで, 5 年経過でいずれも障害程度が強くなった。これらの検 查成績を従属変数, 年齢を共変量, 検査年度を要因と して一元配置分散, 共分散分析を行い, 共変量として の年齢の影響を除去すると, 痛覚域值については検査
年度の要因効果が認められ $(\mathrm{p}<0.001)$, 加齢因子以外 の経年性の悪化因子の存在が推測されたが, 握力, つ まみ力抢よび $125 \mathrm{~Hz}$ 振動覚域值については検查年度 の要因効果は認めれれず $(\mathrm{p}>0.1)$, 主として加齢に伴 ら検査成績の悪化と考光られた。

\section{8. 大動脈弓の臨床的意義（第 1 報）各年代におけ る突出度}

日本医大第二内科

加藤 仁志, 森島 明

村松 忠, 赫 彰郎

東京顕微鏡院柳川 宗彦, 氏井 重幸

目的：大動脈弓形態の詳細は検討は血管造影法など により行なわれるが,一般検查項目の胸部単純 X 線写 真正面像でもその形態評価はある程度可能と考える. しかし従来の大動脈計測法には測定点の設定などに問 題があり，未だ確立されたものはない，そこで我々は 客観的かつ簡便で臨床的に使用し得る大動脈弓の計測 法を考案した. 大動脈弓の臨床的意義について検討す るにあたって, まず健常者に括ける我々の指標の標準 值を求めた。

対象：都内某事業所職員の昭和 59 年度健康診断受診 者のうち, 明らかな心肺疾患例，降圧剂服用例を除き， 動脈硬化の危険因子を持たない健常者（<B.M.IX $20.7 \times 1.2,<160 / 95 \mathrm{mmHg}, \mathrm{T}-\mathrm{CHO}<250 \mathrm{mg} / \mathrm{d} l$, HDL-C 男 $>40$, 女 $>45 \mathrm{mg} / \mathrm{d} l$, U.A 男 $<7.5$, 女 $<5.8$ $\mathrm{mg} / \mathrm{d} l$ ) 1,835 例（男733，女1,102）(年齢18～74歳）を 標準値算出の対象とした。

方法：通常の方法により撮影距離 $90 \mathrm{~cm}$ で撮影した 間接胸部単純 X 線写真 $(100 \mathrm{~mm})$ 正面像の大動脈弓 （縮小率 $1 ： 3.6$ ) について次の作図から求める Index $\mathrm{a}, \mathrm{b}, \mathrm{c}$ (以下 $\mathrm{a}, \mathrm{b}, \mathrm{c}$ ) (mm) をシャーカステン上で $1 \mathrm{~mm}$ 目盛間隔のスケールを用いて計測した。作図：ま ず気管分岐部を原点とする直交座標を設定する。第 1 象現で座標軸を 2 辺とし，大動脈弓に外接する長方形 を作り，糈を $\mathrm{a}$ ，横を b とする。また原点より 45 度の角 度で引いた直線が大動脈弓と交わる点を求め, 原点か らの距離を c とする。

結果：a, b, c は各々年齢の増加とともに延長し, 経 年的要因の関与が示唆された. 20 代前半と比べ, 男性 では a は 40 代後半, b は 20 代後半, c は 30 代後半から, 女性では $\mathrm{a}, \mathrm{c}$ は 30 代後半, b は20代後半から有意に延 長した． 60 歳以上の群の $\mathrm{a} ， \mathrm{~b} ， \mathrm{c}$ は40代やそれ以前の 群と比べ有意な延長がみられた。（以下 $\mathrm{a}, \mathrm{b}, \mathrm{c} の$ 順に 
$\mathrm{M} \pm \mathrm{S} . \mathrm{D}$ を示す）男：（20代） $8.6 \pm 1.7 ， 9.3 \pm 0.9$, $10.9 \pm 1.2$ (40代) $9.3 \pm 1.9 ， 10.2 \pm 1.0,12.0 \pm 1.6$ (60 歳以上) $10.4 \pm 2.8,10.8 \pm 1.5,13.1 \pm 1.3 女 ：(20$ 代) $7.2 \pm 1.3,8.5 \pm 0.9,9.5 \pm 1.1$ (40代) $8.2 \pm 1.6,9.3 \pm$ $0.9,10.4 \pm 1.3$ (60歳以上) $11.0 \pm 1.7,10.7 \pm 1.2$, $13.3 \pm 1.5$.

\section{9. 高齢者の体表面電位図の検討}

岡山大第一内科 中尾 陽, 山田 信行 斎藤 大治, 長島 秀夫 岡山大中検 吉田 英紀, 原岡 昭一

目的：高齢化社会への移行に伴い高齢者の循環器疾 患の発症はますます多くなり, 電位図の虚血性心疾患 などへの臨床応用が盛んになる中で，基礎となる健常 高齢者についての報告は少ない，そこで高齢者の電位 図を健常成人例と比較検討した。

対象と方法：対象は，標準12誘導心電図とベクトル 心電図とが正常, 標準体重の $\pm 20 \%$ 以内, 正常血圧, \% 肺活量と 1 秒率とが正常, マスター負荷試験陰性の条 件を全てみたす20歳から81歳までの 296 人を, 男女別に 若年, 中年, 高齢者の 6 群に分けた。

結果：平均電位図は, QRS 開始より $10 \mathrm{msec}$ の時点 では, 高齢者群ほど男女とも極大は下方に, 極小は上 方に偏位し零電位線はより胸骨中線と平行になった。 $30 \mathrm{msec}$ の時点では, 女性では, 高齢者群注ど G4を中 心に左前胸部から左背部の陽性電位が有意に高くな り, 右側胸部から右背部の陰性電位は浅くなり, 逆に 男性では，陽性電位は小さくなり，背部の陰性電位は 浅くなった．各誘導点毎の最大陽性電位 $(\mathrm{Rmax} V)$ と 最大陰性電位 $(\mathrm{SmaxV})$ に打いては，加齢とともに， $\mathrm{RmaxV}$ は，男性では前胸部上方と左側背部下部で小 さく，女性では逆に左前胸部から背部で大きく， $\mathrm{SmaxV}$ は, 男女とも前胸部下部で浅くなった。加齢と ともに, RmaxV, SmaxV とも男女差が少なくなった。 $\mathrm{QRS}$ 終末より $60 \mathrm{msec}$ の時点での ST 電位図では，男 女とも極大の位置は F4であるが, 背部上方の極小は加 齢とともに下方に変位した。加齢とともに，左前胸部 の陽性電位は小さくなり, 右背部から右側胸部の陰性 電位は浅くなった。陽性電位は男性が有意に大きかっ た。これらの要因として加齢による，心起電気力，肺 のインピーダンス，心筋の萎縮などの変化や，女性で は，さらに乳房や皮下脂肪組織の変化などが考兄られ た。高齢者の電位図は若年者や中年者のそれと比較し て明らかに差異があり高齢者の電位図を検討する時に
十分な注意が必要と考えられた。

270. 発作性上室性頻拍症のタイプ別頻度およびその 年齢分布からみた特徵

日本医大第一内科

$\begin{array}{llll}\text { 飯田 } & \text { 恵子, 平山 悦之, 後藤 } & \text { 正道 } \\ \text { 小林 } & \text { 義典, 洪 } & \text { 基哲, 新 博次 } \\ \text { 加藤 } & \text { 貴雄, 早川 } \text { 弘一 }\end{array}$

目的：発作性上室性頻拍症（PSVT）のタイプ別頻 度, 抢よび加齢と PSVT の関係を明らかにするため本 研究を行った.

対象と方法：日本医科大学第一内科にて過去 10 年間 に電気生理学的検查 (EDS) を行った644例（男400例, 女244例）のうちその発生機序のタイプを診断し得た PSVT 125例 (男78例，女47例)を対象とし，タイプ別 頻度, 年齢分布を調査した。房室結節内リエントリー （AVNRT）扣よび WPW 症候群など側副伝導路を介 する房室間リェントリー（AP）例のうち潜在性 WPW 症候群では右房頻回刺激法により Wenckebach 周期 が出現する心房刺激周期 (WCL), 右房期外刺激法によ り房室結節有効不応期 (ERPAVN), おょび房室結節 機能的不応期（FRPAVN）を測定した。

結果: (1) PSVT 125例のうちAVNRTは52例 (41.6\%)，AP が73例(58.4\%)であった。（2）EPSを 施行した644例の検查施行時の平均年齢は52.5歳で あったのに対し, PSVT は比較的若年者に多く44.3土 16.4歳であった。（3）PSVTのタイプ別ではAVNRT

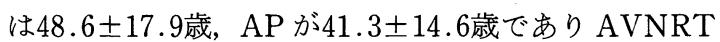
はAPに比し年齢が有意に高い傾向にあった（p< 0.025).（4）自覚症状から推定した初発年齢は PSVT 全体で平均 $34.0 \pm 16.7$ 歳であり, タイプ別では

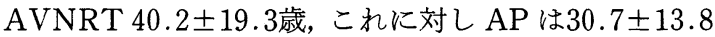
歳と初発年齢も同様にAVNRT はAP に比し有意に 高い傾向を示した $(\mathrm{p}<0.025)$.（5）WCL, ERPAVN の延長がみられたのは, AVNRT, AP ともに少数例の みであったが，FRPAVN が525msec 以上と延長して いた例が AVNRT では26例中 5 例(19.2\%), AP では 19 例中 3 例 $(15.8 \%)$ と, FRPAVN の延長している症 例が比較的多くみられた。

結論：PSVTは比較的若年者に多くみられるが, AVNRT A APよりその発症が遅く, AVNRTでは その発症に FRPAVN の加齢による延長が関与して いることが示唆された。 
271. 発作性上室性頻拍の臨床像と電気生理学的所見 一年齢および機序別の検討

\section{長崎大第三内科}

橋本 隆明, 清水 昭彦, 植山 千秋 森 光弘, 谷川 宗生, 北野 幸英 木谷 文博, 深谷 真彦, 矢野 捷介

橋場 邦武

発作性上室性頻拍 (PSVT)の機序として, 顕性ある いは潜在性 WPW 症候群による房室回帰性頻拍抒よ び二重房室伝導路による房室結節リエントリー性頻拍 などがある，今回我々は，これらの機序のうち，顕性 WPW 症候群がない例の PSVT 機序のなかで半々の 症例数を占める潜在性 WPW 症候群, 二重房室結節伝 導路, これら 2 つ機序によるPSVT 例の臨床像を電 気生理学的所見と対応しつつ，年齢および機序別に検 討し，若干の知見を得たので報告する。

対象拉よび方法：対象は，頻拍発作歷があり，電気 生理学的検查 (EPS) を施行した潜在性 WPW 症候群 による房室回帰性頻拍（AVRT）28例と二重房室結節 伝導路による房室結節リエントリ一性頻拍 (AVNRT)31例の計59例である。これらの症例につい て, 若年群 (39歳以下), 壮年群 (40歳以上59歳以下), 老年群 (60歳以上) に分け, 臨床像と EPS 所見を対比 検討した.

結果：PSVT の機序により入院時の年齢分布に差 があり,AVRT は若年群に多く, AVNRT は老年群に 多かつた。発作頻度は程度により 3 段階に分けェコー 誘発域の幅と対応したが, AVRT では若, 高年群で発 作頻度が高く，エコー誘発域の幅は若，壮，老年群の 順に短縮傾向を示した。頻拍持続時間についても 3 段 階に分け房室結節順行性不応期と対応したが，AVRT では持続時間が年齢と共に延長傾向を示し，房室結節 有効不応期は年齢と共に短い症例が増加する傾向を示 した. AVNRTでは発作頻度は年齢と共に増加傾向を 示したが，持続時間については，年齢群間で大差はな かった。

総括：我々は第27回本学会でPSVT の初発時年齢 には機序別に差異のある事を報告した。 今回，さらに 発作の頻度や持続時間などを合わせて検討することで 機序別の年齢による臨床像の特徵を明らかにし，臨床 像からの機序の推定も可能になると思われた。

272. 老年高血圧患者における重症型心室性不整脈に 対するMexitil の有効性および安全性
船橋市立医療センター内科

片桐 誠, 山田 雅子, 今井均
工藤一彦, 小沢 俊, 茂又 䢐祐

目的：加齢により心室性不整脈が増加する事は Fleg らにより報告されているが，その成因は不明であ る。今回，我々は心室性不整脈に括壮る高血圧の役割 を検討した。

対象揖よび方法：36から86歳までの高血圧患者 (WHO 分類 I, II 期) 执よび正常血圧患者計135例を対 象とした。36から69歳を中壮年，70歳以上を老年とし 高血圧・老年群（I 群）27例, 高血圧・中壮年群 (II 群) 29例, 正常血圧・老年群（III群）29例，正常血圧・ 中壮年群（IV群）50例に分類した。外来に扮いて全例 に Holter 心電図, 心臓超音波検査を行ない, 一回拍出 量, 心拍出量, 左室駆出率 (EF), 左室内径短縮速度 （mVcf）を算出した。心室性不整脈の重症度は Lown 分類に従った。

結果 : 年齢は I 群 74 歳, II 群53歳, III群 75 歳, IV群 51歳であり，I－III群およびII一IV群間に差異を認め なかった。血圧は I - II 群間，III一IV群間に差異を認 めなかった. Grade 4a 以上の心室性不整脈の頻度は I 群 $37 \%$, II 群 $14 \%$, III群 $0 \%$, IV群 $2 \%$ であり I 群で 有意に大であった。また心機能に扔いては I 群で $\mathrm{EF}$ が $64 \%$ と, mVcf も 1.06circ/sec と有意に小であった。 Holter 心電図を再施行し再現性を確認した後で, Grade 4a 以上の心室性不整脈を伴う老年高血圧患者 10例に対し Mexitil 300mg を投与し治療した。1 1 月 後に Holter 心電図, 心臓超音波検查を再施行し Mexitil の有効性おょび血行動態に対する影響を検討し た。全例に沶いて速拍型心室性不整脈が見られなくな り，心室性不整脈数は996から132/日へと減少した。ま た血圧，心拍数， $\mathrm{EF}, \mathrm{mV} c f$ に変化を認めなかった。 一方, 老年者に颃いて生じやすい排尿障害, 消化器症 状等の副作用は認められなかった。

結語：これらの事より老年高血圧患者の治療に拈け る Holter 心電図の重要性拉よび心室性不整脈の治療 における Mexitil の有効性, 安全性が認められた。

\section{3. 脚ブロックの出現頻度一加齢変化と男女差につ} いて

朝日生命成人病研究所

$$
\begin{aligned}
& \text { 今鷹 耕二, 北原陽之助 } \\
& \text { 中岡 秀光, 藤井 潤 }
\end{aligned}
$$

目的：心電図脚ブロックの年代別出現頻度を，長期 
観察結果をもとにして算出した.

方法：昭和 44 年以降の 16 年間に当研究所に通院し, 心電図を記録した20歳以上の患者すべてを対象に，そ の初回記録14,794枚について脚ブロックの出現頻度を 求めた。次に長期観察の途中から出現した脚ブロック についても年㱓別出現頻度の評価に加えるため累積記 録をもとにした脚ブロックの頻度を検討した。すなわ ち長期観察中に患者の年齢が 10 歳毎に区切った年代の 一つ上の年代に達した際には，この一つ上の年代でも カウントを一つ増やす方式で各年代の記録を累積した ものをもとにして年代別出現頻度を算出した。

結果と考察：初回記録のみをもとにした脚ブロック の年代別出現頻度では80歳以上の女の脚ブロックが $7.4 \%$ に対し男で $2.9 \%$, 左脚ブロックでは女 $0 \%$ に対 し男 $1.4 \%$ なと不自然な分布となる。これに対し，累積 法では加齢に伴う頻度の増加が極めて自然に表現され る.すなわち右脚ブロックは男では 40 歳代まで $1.5 \%$ 前 後であり, 加齢とともに増加し，80歳以上では7.9\%に 達した，女では中年までは男より低率であったが，70 歳代以降男女差は消失した。左脚ブロックは男女差が なく，加齢とともに増加し，80歳代では男 $1.8 \%$ ，女 1.6\%であった。累積の効果は基礎疾患を有し, 長期通 院する老年者ほど強くみられるが，一方，一過性の脚 ブロックを含めて途中から出現した右脚ブロック 123 例，左脚ブロック17例を評価に加えることが可能であ るなど，一般に括こなわれる断面調査での成績よりも 臨床の場での頻度を忠実に表現している。

\section{4. ラットの心電図と加齢}

高知医大老年病科

高知医大第一生理

目的：ラットは実験的研究に最も高頻度に用いられ る実験動物であるが，ジギタリス抵抗性であるといら 特徵を有する。そこで, ラットの心電図所見に及ぼす 加齢の影響を検討するとともに，ジギタリス感受性に 影響する因子につき検討し，その一つとして加㱓の影 響についても検討した。

方法：STD : Wistar rat $(n=65)$ を年齢別に 5 群に 分類した；第 1 群 $(7 \sim 10 \mathrm{~W}, \mathrm{n}=7)$, 第 2 群 $(11 \sim 20$ $\mathrm{W}, \mathrm{n}=21)$, 第 3 群 $(21 \sim 30 \mathrm{~W}, \mathrm{n}=18)$, 第 4 群 $(55 \sim 85$ $\mathrm{W}, \mathrm{n}=9)$, 第 5 群 ( $100 \mathrm{~W}$ 以上, $\mathrm{n}=10)$. さらにジギ タリス感受性を検討するため SLC：Wistar/ST（n= 24）を用いた. ECG 記録はウレタン麻酔下に腹臥位に
て， X, Y, Z スカラー心電図 (高安法, TC 0.01 秒) と第 2 誘導 (TC2.0秒) を記録した。ささら $\mathrm{X}, \mathrm{Y}, \mathrm{Z}$ スカラー心電図を $80 \mathrm{~Hz}$ の high-pass filter を経て各々 2,000 回加算平均しヒス束電位を記録した. ジギタリス 不整脈は ouabainあるいは $\beta$-methyl-digoxin を 1 , $3,5,10,15,20,25,30,35,40,45,50,55$, $60 \mathrm{mg} / \mathrm{kg}$ を30分毎に腹腔内投与し作製した。

結果ならびに考案 : 加齢と心電図 RR 間隔は第 1 群ラット $162.0 \pm 19.0 \mathrm{msec}$ で，第 4 群で $191.4 \pm 22.3$ msec と延長 $(\mathrm{p}<0.05) . \mathrm{PQ}$ 時間は第 1 群 $44.3 \pm 3.6$ msec で第 3 群より $52.3 \pm 5.8 \mathrm{msec}$ と延長し第 5 群で $62.7 \pm 10.2 \mathrm{msec}$ 迄延長 $(\mathrm{p}<0.001)$. QRS 中は第 1 群 $18.0 \pm 1.9 \mathrm{msec}$ で, 第 5 群で $26.6 \pm 4.1 \mathrm{msec}$ 延長 $(\mathrm{p}<0.001)$. 加龄とヒス束心電図 ヒス束電位が記録 できた第 12 群中 8 例と，第 5 群中の 5 例について $\mathrm{RR}, \mathrm{PQ}, \mathrm{QRS}, \mathrm{AH}, \mathrm{HV}$ 時間を比較した。 $\mathrm{AH}, \mathrm{HV}$ 時間はそれぞれ $(23.1 \pm 2.3 \rightarrow 29.3 \pm 3.3 \mathrm{msec}),(8.6 \pm$ $1.9 \rightarrow 12.6 \pm 0.9 \mathrm{msec})$ と有意に延長した $(\mathrm{p}<0.01)$. 加齡とジギタリス感受性 ラットは $\beta$-methyldigoxin に抵抗性で心室性不整脈は誘発されなかった が， ouabain に対しては dose-related に伝導障害，心 室性不整脈の出現が観察された。 ouabain 感受性は STD: Wistar に比し SLC：Wistar/ST で大であっ た、また第 1,2 群ラット中の 12 例，第 3 群ラット中 6 例の心室頻拍誘発 ouabain 量はそれぞれ33.8土4.8 $\mathrm{mg} / \mathrm{kg}, \quad 44.2 \pm 2.0 \mathrm{mg} / \mathrm{kg}$ であり加㱓とともに ouabain 感受性が低下する $(\mathrm{p}<0.001)$ こど推測さ れた。

\section{5. 発作性上室頻拍と加齢との関係}

東京船員保険病院内科

内田 宏子, 薄元 茂, 加地 紀夫 邱忠正, 石井真理子, 小澤 興

村上 徹, 大谷 麗二, 広瀬 麟也 原医院原敏夫

目的：40歳以上の健常中高年者に対して, Holter 心 電図検査を行い，発作性上室頻拍と加齢との関係を検 討した。

対象と方法：対象は血圧値, 胸部レントゲン写真, 12誘導心電図で異常を認めない40〜87歳の健常中高年 者91名 (平均年齢62歳)である. Holter 心電図は $\mathrm{CM}_{2}$ と $\mathrm{CM}_{5}$ とを記録し, 全波形を圧縮心電図に再生し, こ の圧縮心電図で発作性上室頻拍を認めた時間帯をすべ て実時間心電図に再生して解析を行った。発作性上室 
頻拍の定義は，一心拍で $\mathrm{R}-\mathrm{R}$ 間隔が $33 \%$ 以上急に短 縮し, 三拍以上続き, 頻拍中の $\mathrm{QRS}$ 波形が洞調律時と 同じである場合とした。

結果: 全例に打㤝発作性上室頻拍の出現率は28/ 91例（31\%）で, 出現回数は合計63回, 心室頻度の平 均は125/分 (92 179/分), 持続の平均は 6 心拍 ( $3 \sim 21$ 心拍), 先行洞調律時の三心拍の平均は72/分(53 110/ 分）であった。頻拍中症状を訴光た者は扮らず，いわ ゆる benign slow paroxysmal atrial tachycardia に 属するものが大部分であった. 出現時刻には一定の傾 向を認めなかった。 63回の出現のうち， $\mathrm{P}$ 波の解析が 可能であった 57 回で $\mathrm{P}$ 波の形を検討すると，頻拍の第 一拍目以降で逆行性 $\mathrm{P}$ 波と考光られた $\mathrm{P}$ 波は一回の み認め, 他はすべて陽性のP波と考えられ，これらの $\mathrm{P}$ 波の形は洞性時の $\mathrm{P}$ 波とは異なると推測されたも のが大部分であった。年代別に検討すると，出現率は 40 代 $10 \% ， 60$ 代 $29 \% ， 80$ 代 $75 \%$ と出現率は加齢ととも に増加した。 しかし, 心室頻度, 持続心拍数, 先行心 拍数などの各々の平均では，年代間で一定の傾向を認 めなかった。 また男女の差でも一定の傾向を認めな かった。

結語：健常中高年者に扔いて, 発作性上室頻拍の出 現率は加齢とともに増加し, 他の不整脈々同じ傾向を 認めた。これらの発作性上室頻拍の出現機序として, $\mathrm{P}$ 波の形及び $\mathrm{P}$ 波と $\mathrm{QRS}$ 波との関係から心房期外収 縮の連発が示唆され，心房に対する加齢の影響と推測 した。

\section{Holter 心電図法による高齢者の不整脈につい ての検討}

群馬大第二内科 内藤 滋人, 田村 友秀 伴野 祥一, 村田 和彦

目的：高齢者の不整脈については, 若年者との比較 検討において，様々な報告がなされている，今回我々 は70歳以上の外来通院患者を対象にして高齢者間での 心拍数及び不整脈の比較を行らことを目的として, Holter 心電図法を用いて検討を行った。

対象：明らかな心疾患及び脳血管障害の既往を有さ ない（但し高血圧性心臓病は除外しないこととした） 70 歳以上の外来通院患者 71 例 (男 21 例女 50 例, 平均年 齢78.7士5.4歳）に Holter 心電計を装着した。71例を 70 歳代38例，80歳以上 33 例の 2 群及び高血圧を有さな い32例，高血圧を有する39例の 2 群に分けた。なお高 血圧は収縮期血圧 $170 \mathrm{mmHg}$ 以上, 拡張期血圧 100
$\mathrm{mmHg}$ 以上のものとした. Holter 心電図の解析はす べて肉眼にて施行した。

結果：(1) 心拍数は, 昼間 $78 \pm 10 /$ 分, 夜間 $68 \pm 9 /$ 分 と有意の差 $(\mathrm{p}<0.01)$ を示したが, 年齢, 性別, 及び 高血圧の有無については，有意の差は認めなかった。 (2) PAC は71例中68例 (96\%) に認められ，70歳代よ り80歳以上の群に打いて昼間出現数及び 1 日総数に抒 いて有意に多数の出現を示した $(\mathrm{p}<0.05)$ が, 高血圧 の有無との関連は少なかった。（3）benign slow paroxysmal atrial tachycardia は71例中39例 (55\%) に 認められ，80歳以上の群及び高血圧群に米いて有意に 出現例が多い傾向が認められた $(\mathrm{p}<0.01)$. (4) PVC は71例中57例 $(80 \%)$ に認められ昼間の方が夜間に比 し出現数が多かった $(\mathrm{p}<0.05) . P A C$ とは逆に年齢に おける有意の差は認められず, 高血圧を有さない群に 比し高血圧を有する群に扔いて, 昼間, 夜間, 1 日総 数ともに有意に出現数が多い傾向が認められた（ $\mathrm{p}<$ 0.005). Lown 分類に打いても高血圧を有する群にお いて重症不整脈が多い傾向が示唆された。（5）90歳以 上の 2 例はいずれも夜間 $\mathrm{A}-\mathrm{V}$ block を生じそのうち 1 例は約 4 秒間の心停止を認めた.

以上高齢者に扮ける不整脈の特徵を踏采今後予後 との関連に扣いて検討を加えたいと思う。

\section{7. ホルター心電図（DCG）による上室頻拍の出現} 様式に関する検討一とくに加齢の影響を中心に 東海大内科

$$
\begin{aligned}
& \text { 古屋 } \text { 秀夫, 田辺 晃久, 北田守 } \\
& \text { 吉川 広, 五島雄一郎 }
\end{aligned}
$$

目的：上室頻拍 (SVT) の1日の出現時間帯をホル タ一心電図法 (DCG) を用いて解析し，加齢や心疾患 の有無で比較することにより,SVT の出現に影響を与 える因子について検討した.

対象・方法：対象はDCGにより SVT (SVPC10連 発以上）が認められ，抗不整脈薬，ジギタリスの投与 を受けていない39例である。年齢は65.9土 10.4 (46 84) 歳であり, 老年者（65歳以上）20例, 非老年者 (65歳未満) 19例, 器質的心疾患例 (OHD) 18例, 非心疾患例 (NHD)21例であった. DCGの解析 は圧縮心電図記録装置（フクダ電子製 TR-210）を用 い, 実時間心電図で確認した. SVT の出現時刻により 覚醒時のみ $(A)$, 睡眠時のみ $(S)$, 覚醒・睡眠時とも (AS) に分け，(A) はさらに18時以前のみ (AD), 18 時以後のみ (AE) に分けて検討した. 
結果：SVTの出現時間帯はA $72 \%$, S 13\%, AS 15\%であり覚醒時のみ出現する例が多かった．A 群で は $\mathrm{AD} 64 \%$ (18/28), $\mathrm{AE} 29 \%$ (8/28)であった。 $\mathrm{OHD}$ の割合は A 50\% (14/28), S20\% (1/5), AS 50\% (3/ 6), $\mathrm{AD} \mathrm{50 \%} \mathrm{(9/18),} \mathrm{AE} 38 \%$ (3/8) であり, いず れの間にも有意差は無かった。老年者の割合は A $57 \%$ (16/28), S 20\%(1/5), AS 50\% (3/6), AD 83\%(15/ 18), AE 13\%（1/8）であり，Sに比べて A で老年者 が多く $(\mathrm{p}<0.05), \mathrm{AE}$ に比べて AD で老年者が多かっ た $(\mathrm{p}<0.001)$. 次に夜間出現 SVT の入眠後出現まで

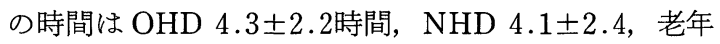
者 $4.1 \pm 1.7$, 非老年者 $4.4 \pm 2.5$ であり年齢, 心疾患の 有無で差はなかった。入眠後 2 時間毎の出現頻度は ( 0 ～1) $11 \%,(2 \sim 3) 17 \%,(4 \sim 6) 50 \%,(6 \sim)$ $22 \%$ であり，4〜5 時間が最も多かった。

結語：(1) SVTの出現様式は覚醒時のみ出現例が $72 \%$ と多かった。(2)覚醒時の久出現例は睡眠時のみ出 現例より老年者の頻度が高く, 特に日中のみ出現例で その傾向は強かった。 (3)老年者に拈けるSVTは器質 的心疾患あるいは交感神経系の関与が考兄られた。

\section{8. 老年者における徐脈性不整脈および房室ブロッ クの日内変動一ホルター法（DCG）による検討 \\ 東海大内科

$$
\begin{aligned}
& \text { 弘瀬哲, 井出 満, 佐藤美智子 } \\
& \text { 田川 隆介, 今岡千栄美, 五島雄一郎 }
\end{aligned}
$$$$
\text { 吉川広, 田辺 晃久, 古尾秀夫 }
$$

目的：徐脈性不整脈と房室ブロックの日内変動を木 ルター心電図 (DCG) で検討し，それらの出現様式お よび頻度を老年者と非老年者で比較した。

対象と方法: 東海大学病院における DCG 連続 4,000 記録, 2,554名を老年群（A 群 $\geqq 65$ 歳，715名）, 中年群 (B 群 $40 \sim 64$ 歳, 1,428 名), 若年群 ( C 群 $\leqq 39$ 歳, 411名)に分け以下の不整脈を分析した。(1)洞徐脈(2)洞 停止(3)徐脈頻脈症候群（BTS）(4)心房細動で slow ventricular response を伴うもの (Af-s) (5)洞房ブロッ ク (SA-B) (6) $\mathrm{I}^{\circ}$ 房室ブロック ( $\left.\mathrm{I}^{\circ} \mathrm{AV}-6\right)$ (7) $\mathrm{W}$ 型房室

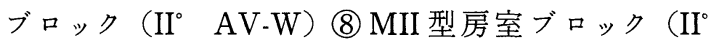
AV-M） (9III度房室ブロック（III AV-b）である.

結果：洞徐脈はA 40名（5.6\%）B 58名 (4.1\%) C 42 名 $(10.2 \%)$ と $\mathrm{C}$ 最も多く, 睡眠時のみの出現例 を比較しても C が最も多かった（各 $\mathrm{C}>\mathrm{A}>\mathrm{C}>\mathrm{B}, \mathrm{p}<$ $0.01)$. 同様に $\mathrm{II}^{\circ} \mathrm{AV}-\mathrm{W}$ も睡眠時にの及出現例は $\mathrm{A}$ 4 名 (0.56\%), B 15名 (1.05\%), C 20名 (4.86\%)
とCに最多かった(各 $\mathrm{p}<0.01)$. 以上より Cの洞徐 脈と $\mathrm{II}^{\circ} \mathrm{AV}-\mathrm{W}$ が A， B に比べ高頻度であることは両 不整脈が同一因子（たとえば迷走神経緊張）により生 ずると示唆された。洞停止, BTS, I $\mathrm{AV}-\mathrm{b}, \mathrm{III}^{\circ} \mathrm{AV}-\mathrm{b}$ はAに多く認められ，とくに III AV-bはA 7 名 (0.98\%)，B 1名 (0.07\%) でCにはなく A が B, C より有意に高頻度だった(各 $\mathrm{p}<0.01, \mathrm{p}<0.05)$. BTS と洞徐脈の年齢, 性をマッチさせ, 就寝時および起床 時心拍数変動を比較すると BTS 4 例は全例ほぼ心拍 数変動がないのに対し, 洞徐脈では 4 例全例が少なく とも就寝時に心拍数が $20 \%$ 減, 起床時には $20 \%$ 増で あった。したがってBTSは洞徐脈と同一因子により 出現するとは考光られず，とくに自律神経に対する影 響は少ないと考兄られた。

総括：DCGによる日内変動パターンなどをみるこ とにより, ある程度まで自律神経の影響, 加齢の影響 および器質的疾患の有無を予知できるものと考光られ た。

\section{9. sleep apnea の出現頻度と加齢}

高知医大老年病科

貞包 典子, 大塚 邦明，小沢 利男

目的：入院中の心疾患患者 82 例, 陳旧性脳血管障害 患者 (CVA) 23例を対象としてホルター呼吸心電図記 録を行い, sleep apnea の出現頻度招よび不整脈発現 と sleep apnea との関連について検討した。

方法：呼吸曲線はホルター心電計第 2 チャンネルに 時定数 3.0 秒で鼻部サーミスターを用いて記録し, apnea は10秒以上続く気流の停止と定義した。無呼吸 持続時間が長い程 $\mathrm{SaO}_{2}$ の低下が大きい(Zwillich ら, 1982)ことより, 重症度を 5 段階 (grade 1：10～19秒, grade $2: 20 \sim 39$ 秒, grade $3: 40 \sim 59$ 秒, grade $4:$ $60 \sim 79$ 秒, grade $5: 80$ 秒以上) に分類した. 第 1 チャ ンネルに記録した心電図の分析に続いて，24時間呼吸 曲線の圧縮記録を行った。睡眠深度の判定は心拍数卜 レンドグラムを用いた判定基準（自律神経22： 252 260，1985)により行った. 対象は, 対照13例(男 13, 52 72歳), 陳旧性前壁中隔心筋梗塞 OMI 16例 (男 15, 女 1, 54 83歳), 労作性狭心症 angina 29例 (男 13 , 女 16, 51 88歳), sick sinus syndrome SSS 17 例 (男 6 , 女 11,56 - 95歳), 神経循環無力症 6 例 (男 2 , 女 4,40 55歳), その他 14 例ならびに CVA 23例 （男13，女10，62８7歳）である.

結果と考察：1） sleep apnea の出現頻度. 一夜30 
回以上出現した症例頻度は対照 $23 \%$, OMI $50 \%$, Angina 35\%, SSS 29\%, CVA 43\%であった. 2) sleep apnea と年齢。心疾患患者(男40, 女42) 飞打ける max apnea index 5 以上の症例頻度は男女それぞれ60歳未 満 (33\%，0\%)，60歳代 (55\%，44\%)，70歳代 ( $80 \%$, $58 \%) ， 80$ 歳以上 $(100 \% ， 50 \%)$ であった. grade 3 以 上の無呼吸が出現した症例頻度は60歳末満 (11\%, $0 \%), 60$ 歳代 $(18 \%, 33 \%), 70$ 歳代 $(33 \%, 17 \%)$, 80 歳以上 $(100 \% ， 33 \%)$ でありいずれも年齢とともに 増大した。 3) sleep apnea の心拍数変動に及ぼす影 響. 心拍数は無呼吸相に一致して徐脈, 換気相に一致 して頻脈の傾向を示し，そのため心拍数トレンドグラ ムは余弦曲線様に変化した. sleep apnea と不整脈々 の関連 SSS 17例中 9 例に括いて grade 2 以上の apnea に一致して洞房ブロックが, OMI の 3 例, CVA の 1 例 に扮いて grade 3 以上の apnea に一致して心室性不整 脈の出現が観察された。

結語：ホルター呼吸心電図法は sleep apnea の心脈 管系に及ぼす影響を検討する方法として有用である。

\section{80 歳以上の「いわゆる健丈者」にみられた不整}

\section{脈一長時間心電図記録による分析}

駿河台日大病院循環器科

内山 隆久, 藤林 陽三, 坂巻 達夫
佐藤 裕一, 服部 達史, 木原 一
高木 高臣, 小島 雅敏, 成宮 一敏
梶原 長雄

目的：いわゆる高齢健丈者の不整脈について検討す るために行った.

方法：明らかな器質的心疾患が認められない 80 歳以 上の 17 症例 (平均年齢 $82.3 \pm 2.6$ 歳, 男性 3 名, 女性 14 名）につき長時間心電図記録を行った。

結果：心拍数は昼間活動時には70 80/分で夜間睡 眠時は60 70/分であった。 上室性不整脈は全症例の $88.2 \%$ に出現したが， $0 〜 2$ 個/時間が $58.8 \%$ にる れ，4 個/時間以上は $5.9 \%$ と少なかった。単発性上室 性不整脈が涹とんどであったが，発作性心房細動や発 作性上室性頻拍症を示す症例もみられた。期外収縮が 全くみられなかった症例は $11.8 \%$ に存在した。な怙, 上室性不整脈は昼間活動時よりも夜間にやや多く出現 する傾向にあった。室性不整脈は $41.2 \%$ に認められ， 昼間活動時に多かった。心室性不整脈の全てが単発性 心室性不整脈で, 多源性心室性不整脈, short run, VT やVFなどはなかった。
結論：「いわゆる健丈」高齢者では，心拍数の日内 変動が加齢とともに減少するといわれているが, 本研 究でも同様のことが認められた。上室性不整脈の出現 頻度は文献にみられるものと同様であったが，心室性 不整脈の頻度はやや少なかった。高齢者に打ける不整 脈の出現頻度は多く, 日常診療で考慮する必要はある が, 器質的な心疾患が存在しない場合には重篤な不整 脈が出現することは少いと考兄られた。

\section{1. 中高齢者の Holter 心電図の検討}

東京女子医大成人医学センター循環器科

窪倉 武雄, 藤岡 達雄, 山口いづみ

堀江 俊伸, 山田 辰一, 泾谷実

著患のない56歳から84歳の 120 例について日常生活 中の Holter 心電図を Avionics 445B を用い記録し, 上室性期外収縮数（一過性心房細動（af）を含む) 'APC'/総心拍数 (THR) 比及び心室性期外収縮数 (VPC)/THR 比と症状との関連について検討した。 心 電図変化に対応する症状は27例 (22.5\%) に認められ た. 全例に上室性期外収縮を認め'APC'/THR 比が 0.01 以下 $30 \%$ で症状は $0.3 \%$ 以上に多く, APC の連 拍又は afによるものであった。 VPC は107例 (89\%) にみとめ VPC/THR 比 0.01 以下 $16 \%$, Lown 2 度以 下であり, 症状との関連は $\mathrm{VPC}>\mathrm{APC}$ 例でも認めら れなかった。一過性 af は10例（8.3\%）に認められた。 従って著患のない中高齢者では上室性不整脈が不整脈 に起因する症状の要因と考只られる.

目的：主として60〜 70歳代の比較的健常者のホル タ一心電図について, 不整脈々自覚症状との関連につ いて検討した.

方法：56歳から 84 歳の 120 例(男74例, 女46例, 60 70 歳代が $92.5 \%$ 占める)で, CTR $52 \%$ 以上の心拡大例, 冠不全, 特発性心筋症, 高血圧性心疾患, 重症糖尿病 扣よびホルター心電図で虚血性 ST 偏位を示す症例を 除き, 軽症高血圧 (WHO stage 1 期以下, 東大 3 内分 類 1 度以下）を含を正常心電図群（軽度の 1 度房室ブ ロックおよび単純右脚ブロックは含めた)を対象とし， 日常生活中のホルター心電図を Avionics 社445B 型 カルジオコーダーにより記録し, 同社 DCG 再生セン ターで解析され異常心電図がすべて再生編集された記 録について, 上室性期外収縮数 (一過性心房細動を含 む) ('APC')/総心拍数 (THR) 比及び心室性期外収縮 (VPC)/THR 比と自覚症状との関連について検討し た. 
結果：心電図変化に対応する症状は27例中 (22.5\%) に認められた。 APCは全例に認められた。'APC' THR (total QRS complex) 比は0.01以下〜30\%であ り自覚症状は $0.3 \%$ 以上て多く, APCの連拍ないし一 過性心房細動 (af)によるものと判定された. 他方 VPC は107例 (89\%) に認められ VPC/THR 比は0.01以下 〜 16\%で, Lown 2 度以下の単発型であり13例 (10.8\%, 男 6 例平均 67 歳, 女 7 例平均 71 歳) $\mathrm{VPC}>$ APC 例に打いても自覚症状との関連は認められな かった。一過性 af は10例(8.3\%, 男 7 例平均 66 歳, 女 3 例平均58歳)に認められた. 全例 APCにより誘発さ れ, 洞調律への回復も円滑であり洞機能不全症候群の 可能性に乏しいと考えられた。 そのうち5例は昼間に 多く出現し 4 例で自覚された. 他の 5 例は就眠中もし くは徐脈時に生じ覚醒もしくは心拍数の増加により消 失した。いずれも就眠中のため自覚しなかった。

総括：60 70代の比較的健常者では連拍型の上室性 不整脈が不整脈に起因する自覚症状の要因と考学られ る.

\section{2. 心房細動における Slow ventricular response と加齢一Holter 心電図（DCG）による検討}

東海大内科

佐藤美智子, 田辺 晃久, 吉川 広
古屋 秀夫, 井出 満, 五島雄一郎

目的：持続性心房細動患者の 2 秒以上心停止 (af 徐 拍）が器質的疾患の有無, ジギタリス血中濃度と関連 するかを検討し，老年者と非老年者で比較した。

対象执よび方法：心房細動例のうち Holter 心電図 施行例95例を 2 群にわけ，65歳以上の老年者群45例・ 64歳以下の非老年者群50例を対象とした.さらに対象 を(1) 2 秒以上心停止例(2)器質的疾患の有無(3)ジギタリ ス単独服用群にわけ，各々で比較検討した。また，17 例で血中ジギタリス濃度（D濃度）を測定し， D 濃度 との関連も検討した。

結果：(1) 2 秒以上心停止例 (af 徐拍) に打いて老年 者群24例 (53\%) と非老年者群32例（58\%）との頻度 に有意差はなかった。 (2) D 濃度は老年者群 $0.85 \mathrm{ng} / \mathrm{d} l$, 非老年者群 $0.80 \mathrm{ng} / \mathrm{d} l$ と有意差はみられなかった。(3) $\mathrm{D}$ 服用例で af 徐拍を有する例も, 老年者群 (27\%), 非 老年者群 (26\%) と出現の差は認められなかった。 (4) 器質的疾患を有し, D 服用例とさらに af 徐拍を伴ら例 とを各々比較したが, 器質的疾患を有する例に af 徐拍 が老年者群 $(67 \%)$ に多い傾向にあったが，非老年者
群 (43\%) と有意差は認められなかった. (5) 1 日心拍 数を 10 万/日以上, 以下に分け，各々を比較すると，老 年者群 $(44 \%)$, 非老年者群 $(24 \%)$ と有意差をもって $(\mathrm{p}<0.01)$ 老年者群での心拍数は少なかった．６器質 的疾患を有せず，D非内服例の af 徐拍と af 徐拍を有 しないものとで各々比較したが老年者群 $67 \%$, 非老年 者群 $57 \%$ と有意差はみられなかった。

総括：以上より老年者群と非老年者群では af 徐拍 を生じる因子は器質的病変の有無の差ではなく他の因 子（例觉ば自律神経）の関与が示唆された。

\section{3. ゲートボールの心拍数および不整脈へ及ぼす影 響一ホルター心電図法による検討 \\ 聖マリアンナ医大第二内科 \\ 三宅 良彦, 朝日 洋一, 亀谷 学 \\ 外園 光一, 渡辺 尚彦, 三川 武彦 \\ 佐藤 忠一, 須階 二朗}

高齢者のゲートボールが，血圧，心拍数，不整脈発 現へいかに影響するかを検討した。

対象：67歳より84歳, 平均74.0歳のゲートボーラー 24例（男19, 女 5 例）である. 対象24例のうち, 疾病 をもたないものはわずか 2 例で，他の 22 例 $(91.7 \%)$ は虚血性心疾患, 脳血管障害, 高血圧症などを有して いた。

方法：ゲーム中を含む24時間のホルター心電図を記 録し, 心拍数の推移, 期外収縮数, ST 変化を調べた。 なお，11例については，ホルター心電図記録とともに， ゲーム前，ゲーム中の血圧を測定した。また，4例は， 公式試合と練習ゲームの心電図所見を対比検討した。

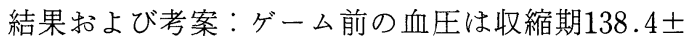
$12.0 \mathrm{mmHg}$, 拡張期 $68.9 \pm 14.2 \mathrm{mmHg}$ であり, ゲーム 中の最高血圧はそれぞれ, $164.5 \pm 21.8 \mathrm{mmHg}, 79.9 \pm$ $11.6 \mathrm{mmHg}$ といずれも有意に増加していた.ゲーム中 の最高心拍数は90 142/分（117.2土16.7/分）で，個 人差は大きいものの, こ我は年齢別最高到達心拍数の 60〜80\%に匹適し，ゴルフなどのスポーツと同程度の 強度と考えられた。 な执, ゲートボールコートの整備 時に心拍数 $150 /$ 分を 20 分にわたり認めた例もあった. ゲートボール中の心室性期外収縮数(拍/時)は, 非ゲー ム時と較らべ, 増加したもの60\%, 減少したもの $15 \%$, 不変 $25 \%$, 増加傾向であったが, 有意差はなかった。 Lown 分類は悪化しなかった。上室性期外収縮数は, ゲーム時と非ゲーム時で差はなかった。

結語：高齢者のゲートボールは，大多数が疾病を有 
するプレーヤーであるが，個々の疾患を十分に考慮し て行光ば, 高齢者のスポーッとして安全と考克られた。

\section{4. 老年者慢性心房細動例と左, 右心房容積の検討} 都老人医療センター循環器科

小林 直彦, 大川真一郎, 今井 保

久保木謙二, 永島 淳一, 千田 宏司

渡辺千鶴子, 平岡 啓佑

都立広尾病院内科杉浦 昌也

目的：慢性心房細動 AF では心房容積が増大するこ とが知られているが, 左, 右心房容積を別々に検討し た成績は少ない。本研究では $\mathrm{AF}$ 基礎疾患により左 心性 (L)，右心性 (R)，孤立性（1）に分村形態的飞算 出した左, 右心房容積, 両房容積について比較検討し た。

方法：60歳以上の老年者連続剖検 1,650 例中の心房 細動209例を心房細動の持続期間により 30 日以上を固 定性心房細動 AF 群 (132例8.0\%, 男66, 女66, 平均 80.4 歳), 30 日未満を一過性心房細動 pAF 群 (77例 $4.7 \%$, 男 47 , 女 30 , 平均 80.7 歳) の 2 群に分類した. また $\mathrm{AF}$ 群を基礎疾患により左心性 (L)：89例, 右心 性（R）：21例, 孤立性（1）：22例の 3 群に分類し臨床 的には心胸郭比, $\mathrm{f}$ 波波高, AF の持続期間, 病理学的 には心重量, 冠状動脈狭窄指数及び既報のごとく左, 右心房容積, 両房容積を算出し検討した。

結果：<臨床的検討>平均心胸郭比は L : $63.8 \%$, $\mathrm{R} ： 57.9 \%, 1 ： 57.5 \%$ て L と R 間 L と 1 間に有意差を 認めた。平均 $\mathrm{f}$ 波波高は $\mathrm{L}: 0.16 \mathrm{mV}, \mathrm{R}: 0.41 \mathrm{mV}, 1$ : $0.10 \mathrm{mV}$ で $\mathrm{L}$ と 1 間, $\mathrm{R}$ と 1 間に有意差を認めた. $\mathrm{AF}$ 群の持続期間は全体で 30 日以上から 12 年までで平均 3.2年であった。 $\mathrm{AF}$ 群と $\mathrm{pAF}$ 群とを比較すると心胸 郭比, $\mathrm{f}$ 波波高に打いて前者が後者に比べ有意に大で あった。〈病理学的検討>平均心重量は L : $412.6 \mathrm{~g}$, $\mathrm{R}: 371.2 \mathrm{~g}, 1: 342.0 \mathrm{~g}$ で L と 1 間に有意差が認められ た. 平均冠状動脈狭窄指数は $\mathrm{L}: 9.7 / 15, \mathrm{R}: 8.7 / 15$, $1: 8.4 / 15$ て L と 1 間に有意差が認められた。平均右房 容積は L : 79.3ml, R: 100.6ml, 1:72.2ml で R, L, 1 の順に大で $\mathrm{R}$ は L 1 より有意に大であった。平均左 房容積は $\mathrm{L}: 76.7 \mathrm{ml}, \mathrm{R}: 81.1 \mathrm{ml}, 1: 61.8 \mathrm{ml}$ で $\mathrm{R}, \mathrm{L}$, 1 の順に大で 1 は $\mathrm{R}, \mathrm{L}$ より有意に小であった。平均両 房容積は L : $156.0 \mathrm{ml}, \mathrm{R}: 181.8 \mathrm{ml}, 1: 134.0 \mathrm{ml}$ で $\mathrm{R}$, L，1の順に大で R は1より有意に大であった. $\mathrm{AF}$ 群 と $\mathrm{pAF}$ 群とを比較すると心重量, 左, 右心房容積, 両 房容積で前者が後者に比べ有意に大であった。また既
報の正常老人心と比較すると各群に扔いて大であっ た。

\section{5. アスピリンの抗血栓作用}

\section{東京医歯大第三内科}

丸山 義明, 沼野 藤江, 沼野 藤夫

目的：アスピリンは，抗血小板剤として古くから用 いられ，その有効性は注涪認められたにも関わらず, 投与量については, 未だに確立されていない. 現在は, 少量投与が広く勧められているが，これらは摘出血管 や，末梢血に和ける抗血小板作用を検討した結果であ り, 少量アスピリンの臨床における有効性の評価は, 今後の課題である，先に我々は，高安病患者の健側肢 と患側肢に打ける, $40 \mathrm{mg}$ と $80 \mathrm{mg}$ のアスピリンの抗血 小板作用を比較し, 病変部位を通過してきた血小板に 対しては， $80 \mathrm{mg}$ のアスピリンが必要であることを報 告した。この結果は, アスピリンの投与量は, 病態に 応じた設定が必要なことを示している。今回我々は, 血管炎, 動脈硬化症患者を対象とし, 少量アスピリン 内服の, 各腫病態による, 抗血小板作用, 血栓症発症 頻度の差について，2 年間追跡し検討したため，その 結果を報告する。

対象及び方法：対象は, 動脈硬化症患者24名（虚血 性心疾患 20 名, TIA 4 名), 高安病15名, Buerger 病 9 名の計 48 名で, 無作為に 2 群に分けたのち, $80 \mathrm{mg}$ アス ピリンを連日または，隔日投与した．投与前，投与後 $1,3,6, \cdots 21,24$ 力月後に打いて, 血小板凝集能, 各種プロスタノイド(Thromboxane $\mathrm{B}_{2}, 6$-keto $\mathrm{PGF}_{1}$ a) を測定した。臨床症状については, 血栓症の発症, 炎症所見の有無について検査した。

結果：高安病患者では, アスピリン $80 \mathrm{mg}$ の隔日投 与にて血小板機能は抑制されたのに対し, Buerger 病, 動脈硬化症患者に扔いては，連日投与を必要とした。 また，連日投与にて 1 カ月後より血小板は有意に抑制 され，24カ月後まで維持された。症状については, 動 脈硬化症患者に打いて, TIA や，狭心症の発症を認め たが, 高安病, Buerger 病に扔いては, 症状の増悪は 認めなかった。

結語：アスピリンの抗血小板作用は病態によって異 なり, 最低, $80 \mathrm{mg}$ の連日投与が勧められる。

286. 老年者の心房細動に対するジギタリス療法の検 討（第 2 報）感受性の元進に関与する因子 
帝京大第二内科

$$
\begin{array}{lrlll}
\text { 田村 治, 馬場 } & \text { 茂樹, 佐藤 } \text { 友英 } \\
\text { 武士 } \text { 彦, 草野 景一, 田沢 秀夫 } \\
\text { 田村 勤, 宮下 英夫 }
\end{array}
$$

目的：昨年の本学会に颃いて，心房細動 (AF) のジ ギタリス抵抗性と感受性の克進について検討し, 感受 性の亢進は老年者で有意に多いことを報告した。今回， 中毒・非中毒の共存する Overlapping Area（OA）拧 上び “感受性え進群”に属する症例を対象として，老 年者の中毒発現に関与する因子を分析した。

対象・方法：CHF のため digoxin 維持療法が不可欠 な243例（洞調律138例, AF 105例, 平均63.5歳）を対 象とし，少なくとも一週間以上投与後の恒常状態下で 血清 digoxin 濃度 (SDC) を RIA により測定．同時に 諸検査を施行した。 (1) AF 105例のらち, OA (SDC : $1.7 \sim 2.7 \mathrm{ng} / \mathrm{m} l$ ) に存在する 36 例を若年者群 (15例) と 老年者群 (21例) に分け臨床成績を比較. (2) OA 内に 打ける老年者を中毒例之非中毒例に分け検討。 (3) “感 受性元進群” (VR $\leqq 59 /$ 分, $\mathrm{SDC} \leqq 2.0 \mathrm{ng} / \mathrm{m} l$ ) と招け る若年者 ( 4 例), 老年者 (13例) を比較検討. (4) “感
受性光進群”に拈忷る老年者の中毒例と非中毒例を分 析.

結果：(1) OA 内で老・若を比較すると，SDC に差は ないが, 老群で 3 倍以上中毒頻度が多く, 心室拍数 (VR)は少なかった. 維持量, 体重, Ccr b老群で低值 を示した。 (2) OA の老年者を中毒・非中毒の 2 群に分 けると, SDC に差はないが, 中毒群で VR が有意に少 なく, 虚血性心疾患 $+\mathrm{DCM}$ が多かった。 また中毒群で $\mathrm{K}$ 保持性利尿薬や $\mathrm{K}$ 製剤の併用が少なかった。 (3) “感

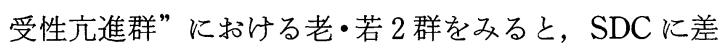
異を認めないが，中毒頻度が若年者で $0 \%$, 老年者で $38.4 \%$ であた. (4) “感受性穴進群”に和ける老年者 の中毒・非中毒 2 群を比較すると, 中毒群で SDC, Cr が高く, VR が少ない傾向がみられた。 2 群間で血清 $\mathrm{K}$ 値に差はないが，中毒群で $\mathrm{K}$ 保持性利尿薬や $\mathrm{K}$ 製剤の 併用がみられなかった。

総括：老年者はジギタリスに対する感受性の克進が 明らかで, SDC (Css. min) の測定はもちろんのこと, 基礎疾患・VR・ K に留意すべきことが結論される。 